$$
\text { بحث بعنوان }
$$

\title{
آليات التعاون القضائي الدولي لمواجهة الجريمة المنظمة
}

\author{
مقدم من الباحث \\ سليمان عبدالواحد عبدالله أحمد محمد لباحد
}

2019 


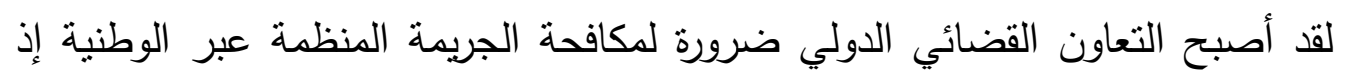

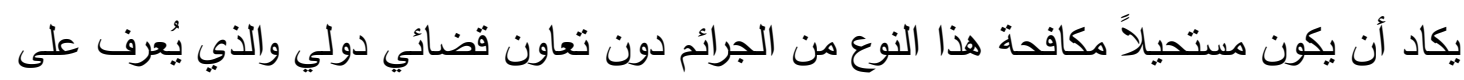

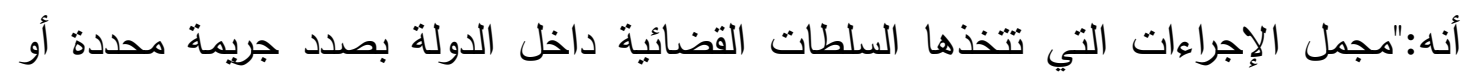

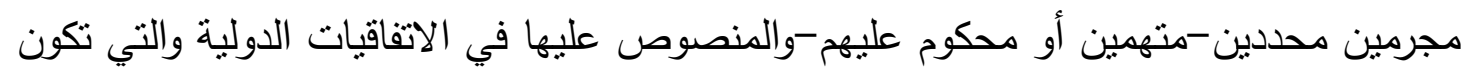
الدول طرفاً فيها بمقتضي النتريعات الوطنية النافذة.(1) كما يعرف التعاون القضائي الدولي في مجال مكافحة الإجرام المنظم على أنه:"تعاون

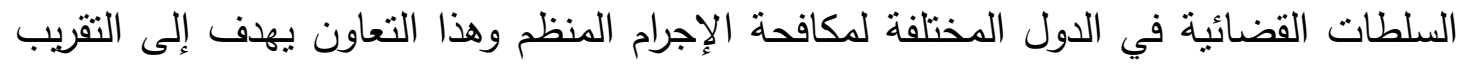

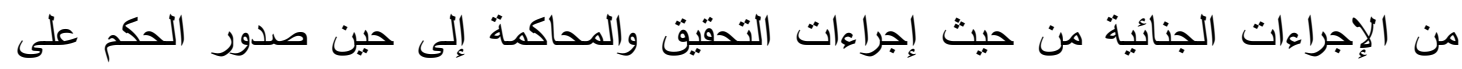

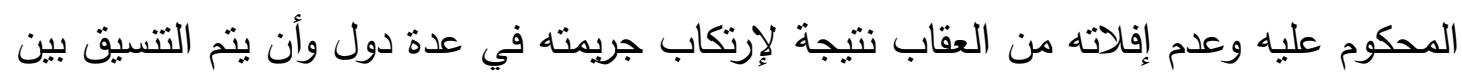

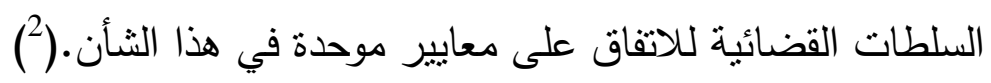
لذللك حرص المجتمع الدولي على التعاون في المجال القضائي فحث على على إبرام الاتفاقيات الثنائية ومتعددة الأطراف في المسائل الجنائية وذلك لاعم التئي التعاون فيما بين الدول وبعضها البعض لمواجهة الجريمة المنظمة عبر الدول.(1)

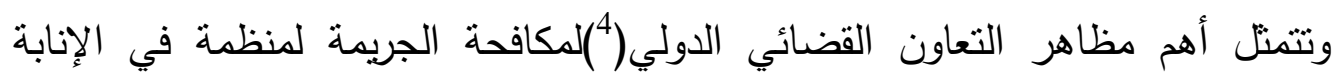
القضائية الدولية وتسليم الجرمين وتتفيذ الأحكام الجنائية الأجنبية.

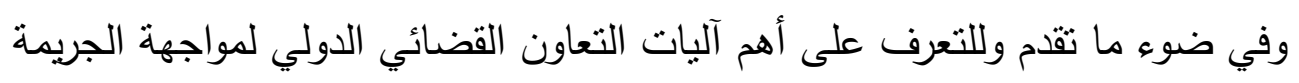

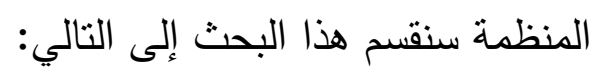
المبحث الأول: الإنابة القضائية الدولية. المبحث الثاني: تسليم المجرمين. المبحث الثالث: تتفيذ الأحكام الجنائية الأجنبية.

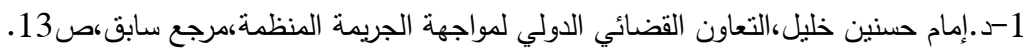

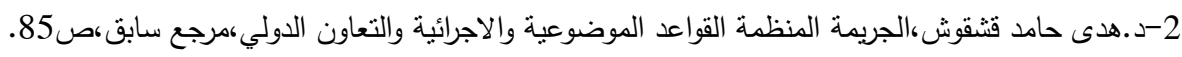

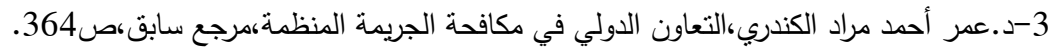

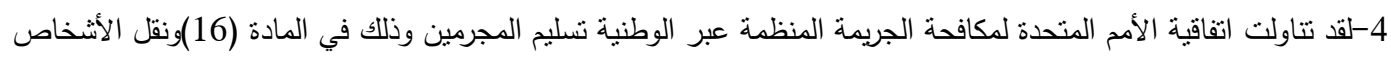

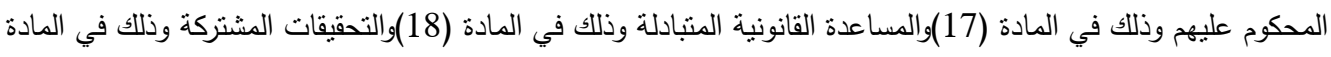

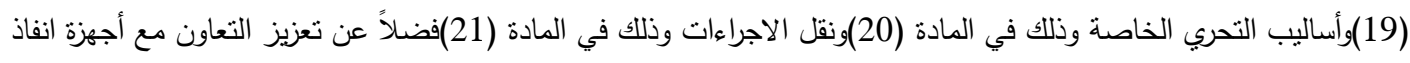

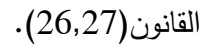




\section{المبحث الأول}

الإنابة القضائية الدولية

\section{تمهيذ وتقسيم:}

لقد أدي تطور العلاقات الدولية وتشـابكها إلي ازدياد الحالات التي يطلب فيها القضاء الوطني لدولة مـا من قضـاء دولة أخري أن يتعاون معه في تتفيذ بعض الإجراءات القضـائية

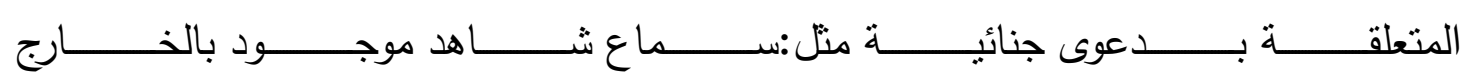

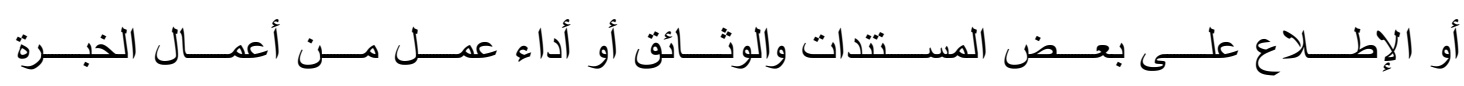
أو المعاينة أو دخول بعض المنازل وتفتيشها....الخ ويكون ذلك عن طريق ما يسمي بالإنابة القضائية الدولية.( (1)

لذلك تعد الإنابة القضائية أداة من أدوات التعاون القضائي الدولي بين الدول حيث تعمل

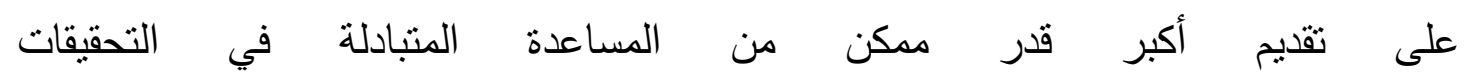
أو إجراءات المحاكمة المتعلقة بجرائم يكون العقاب عليها وقت طلب المساعدة ضمن نطق اختصاص السلطات القضائية في الدولة الطالبة.(2) ولقد أصبح موضوع الإنابة القضائية الدولية أحد الموضوعات الهامة التي طالما نادى بها المجتمع الدولي أملاً في تطبيقها وتعميمها لتحقيق فاعلية أكثر للقوانين الجنائية الدولية ومن الإنهابه ثم كان لهذا الموضوع طابع حضاري يتمبز بصاحيته للتطبيق بسهولة نظراً لاعتماده على المنطق القانوني المستمد من الاتفاقيات الجنائية الدولية(

وفي ضوء ما تقدم وللتعرف على الإنابة القضائية الدولية سنقسم هذا المبحث إلي

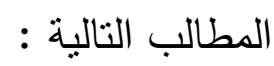
المطلب الأول: تعريف الإنابة القضائية الدولية وتمييزها عن المصطلحات المشابهة. المطلب الثاني: الأساس القانوني للإنابة القضائية الدولية. المطلب الثالث: أسباب طلب الإنابة وبياناته وتتفيذه.

1-د.بدر الدين عبد المنعم شوقي،الإنابة القضائية العربية في المسائل الجنائية،مجلة كلية التدريب والتتمية،العدد التاسع عشر، يوليو 2008م،ص23.

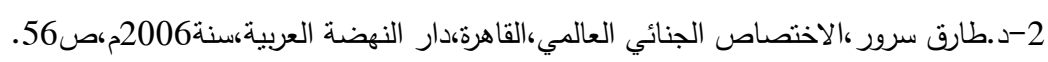

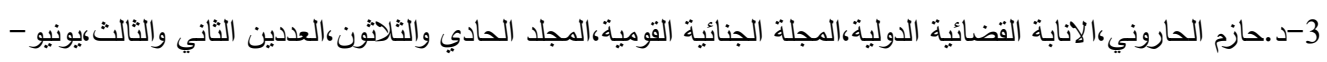

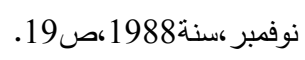




\section{المطلب الأول \\ تعريف الإنابة القضائية الدولية وتمييزها عن المصطلحات المشابهة}

أولاًا-تعريف الإنابة القضائية الدولية:

يوجد تعريفات عديدة ومتتوعة للإنابة القضائية الدولية ويمكن تقسيم هذه التعريفات إلي

ثلاثة اتجاهات رئيسة على النحو النالي:

الإتجاه الأول : ألانهاه

ويخلط أنصـاره بين الإنابـة القضـائية الدوليـة والإنابـة القضـائية الداخلية حيث تعرف

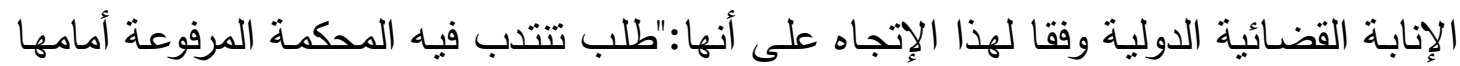
الدعوىهحكمة محل وجود الثـاهد أو الأوراق أو الثـئ أو تتيبها لعمل الإجراء اللازم، وتحرير

محضر بذللك وإرساله لها بعد تمامه" (1)

كما تعرف الإنابة القضائية الدولية وفقا لهذا الإتجاه أيضا بأنها:"عمل بمقتضاه تفوض أنها

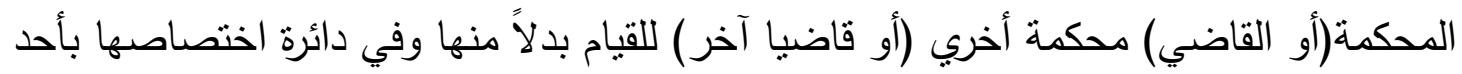

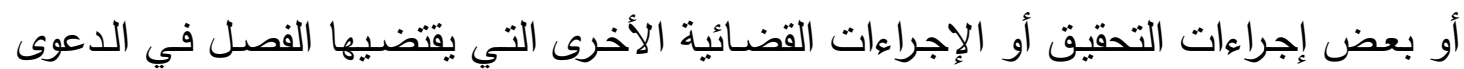

المرفوعة أمامها،والتي تعذر عليها مباشرتها بنفسها بسبب بعد المسافة أو أي مانع آخر "(2) ويقترب من التعريفين المتقدين أيضا ذلك التعريف الذي يعرف الإنابة القضائية الدولية

علي أنها:" تفويض بين سلطة قضائية جنائية إلى سلطة قضائية جنائية أخرى في القيام نيابة الإنة

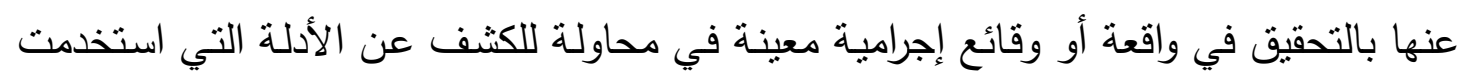

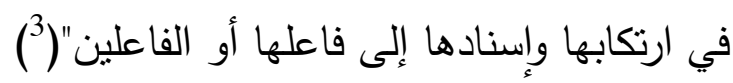

1-د.أحمد عبد الحليم شاكر،الأحكام الإجرائية والموضوعية للمعاهدات الدولية أمام القضاء الجنائي والدولي،رسالة دكتوراهجامعة

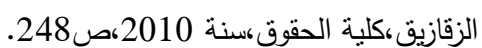
2-د.إدوارد عبد،الإنابات والإعلانات القضائية وفقا لقواعد القانون الدولي الخاص واتفاقية الدول العربية عام 1953م،القاهرة، معهد

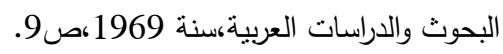
3-د.عمر سالم،الإنابة القضائية الدولية في المسائل الجنائية دراسة مقارنة،القاهرةدار النهضة العربية، سنة 2011،ص15. 


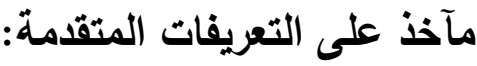

يؤخذ علي التعريفات المتقدة أنها استخدمت تعبيرات واصطلاحات جانبها الصواب عند

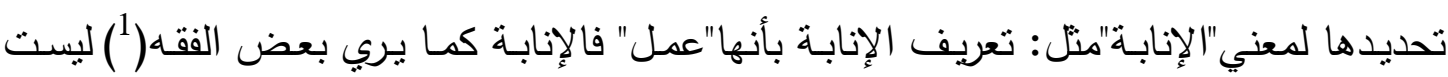

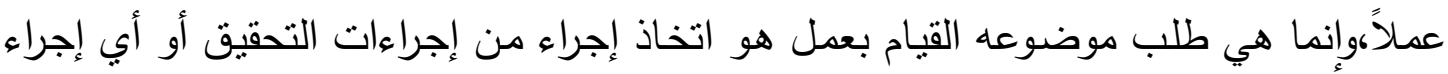

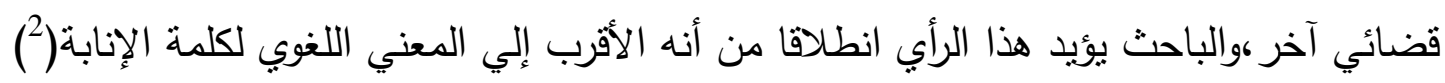

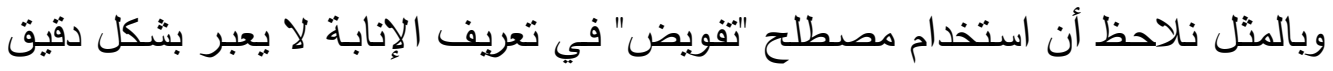

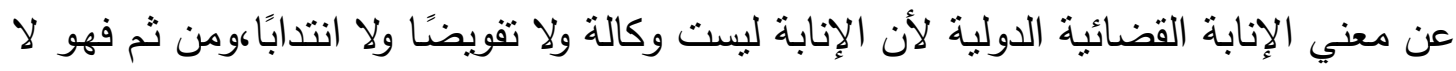

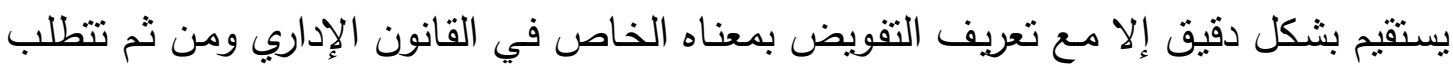
الاقة عدم إقحامه عند تعريف الإنابة القضائية الدولية . كما يؤخذ علي التعريفات المتقدمة كذلك أنها تخلط بين الإنابة القضائية الدولية، والتي

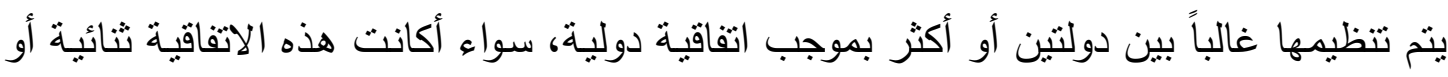

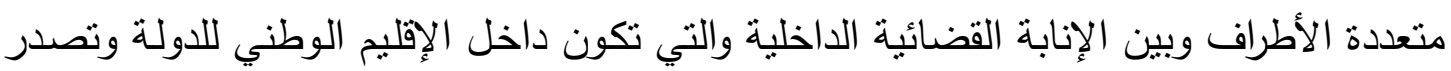
إما من محكمة وطنية إلي محكمة وطنية أخري بنفس درجتها أو بدرجة أدنى منها للقيام مكانها

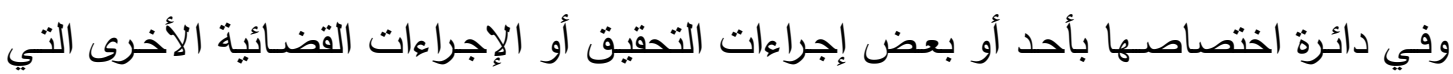

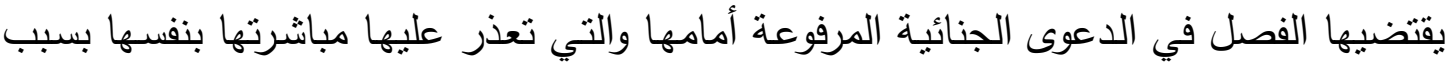

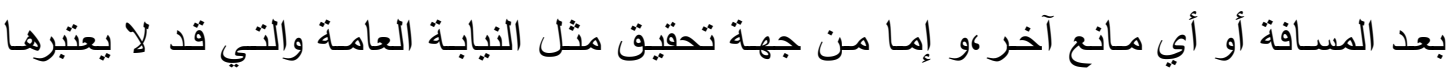

$$
\text { 1- 1 د.عكاشة محمد عبد العال،الإنابة القضائية في نطاق العلاقات الخاصة الدولية،الإسكندرية، دار المطبوعات }
$$

2- إن الجذر اللغوي لكلمة"الإنابة"هو (ناب) و (أناب):يقال(ناب)الثيء نوباً:أبي قرب وناب إلى الثيء: أبي رجع إليه واعتاده .ويقال

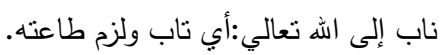
وناب عنه نيابة: أي قام مقامه فهو نائب .ويقال (أناب) فلان إلى الثنيء:أي رجع إلى إليه مرة بعد أخرى وإلى الله تاب ورجع • ويقال أناني

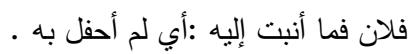
ويقال أناب فلانا عنه في كذا أي:أقامه مقامه .و (ناوبه) في الثيه ألثيء والأمر يعني ساهمه فيه وتداوله معهد بالنوبة. ويقال (تناوب) الأمر :أي قام به مرة بعد مرة والقوم الثيء وعليه تداولوه بينهم وتقاسموه يقال تتاوبوا الماء وتناوبوا العمل والهموم فلانا

تعاقبت عليه.

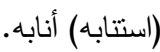

و (النائب) من قام مقام غيره في أمر أو عمل يقال نائب الرئيس ونائب القاضي ونائب الثعب والنائب العمومي.

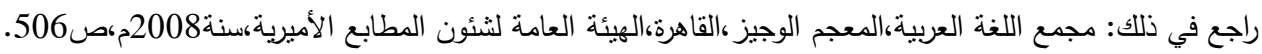


القانون الوطني لبعض الدول من السلطة القضائية،و إما من سلطة تحقيق تابعة لوزارة الداخلية في بعض القوانين الوطنية(1).

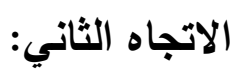

ويقصر أنصاره موضوع الإنابة القضائية الدولية علي بعض إجراءات التحقيق فقط حيث

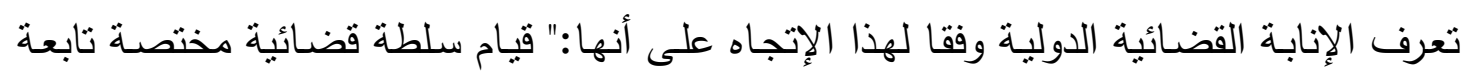

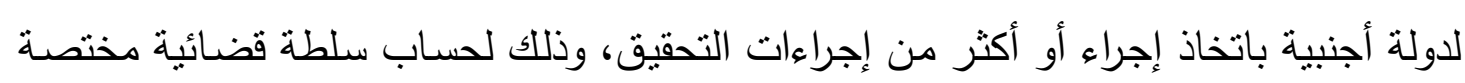

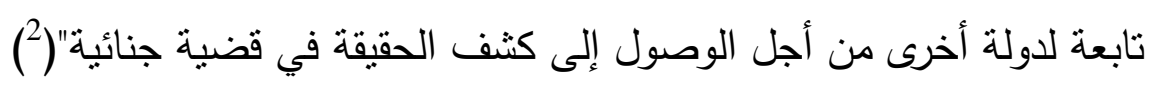

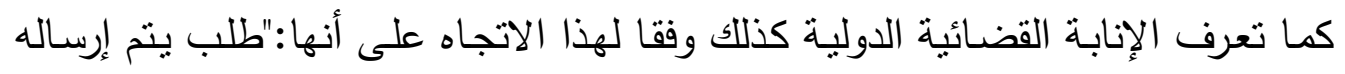
من سلطة قضائية في إحدى الدول إلى سلطة قضائية في دولة أخري لكي تقوم هذه الأخيرة

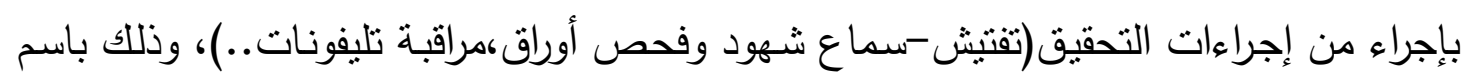

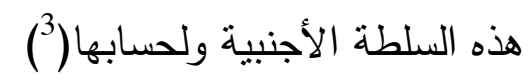

\section{مآخذ على التعريفات المتقدمة:}

يؤخذ علي التعريفات المنقدمة كذلك أنها جعلت نطاق الإنابة القضائية الدولية قاصراً

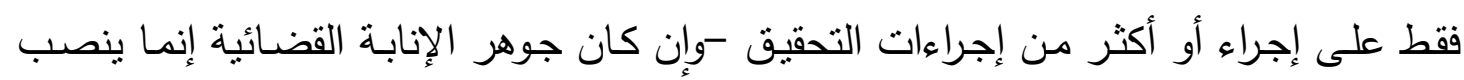

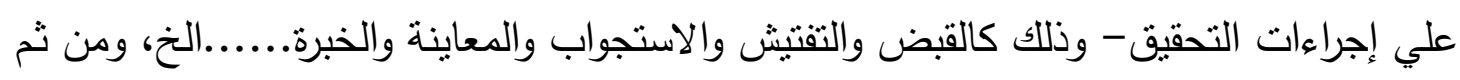

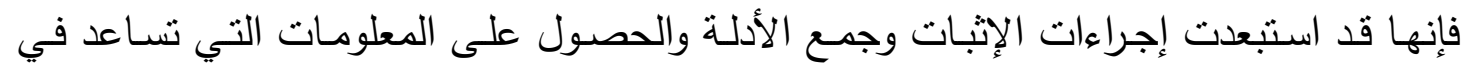

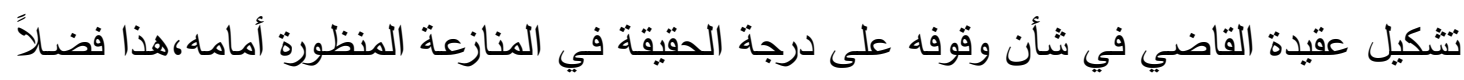
عن استبعادها أي إجراء قضائي آخر يقدر القاضي أهميته في حسم المنازعة المعروضة أمئة أمامهـ. وهذا يضيق كثيرا من نطاق عمل الإنابة القضائية الدولية.

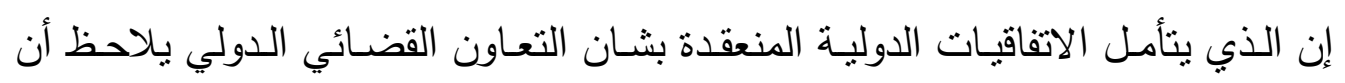

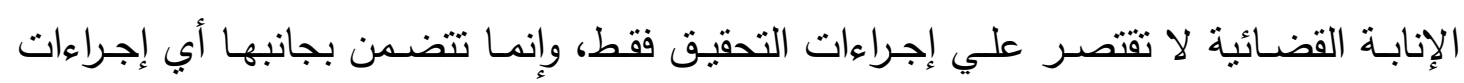
قضائية أخري تتعلق بدعوى منظورة أمام المحاكم الوطنية للاول طالبة الإنابة.

1- تنص المادة( 9)من قانون الإجراءات والمحاكمات الجزائية الكويتي رقم 17 لسنة 1960 على أن" تتولى النيابة العامة سلطة

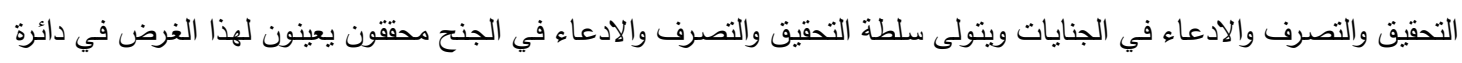

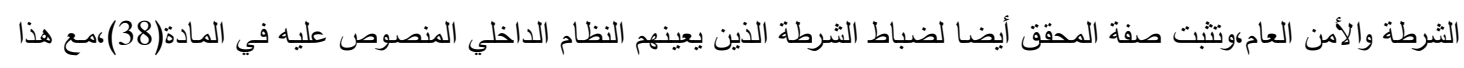

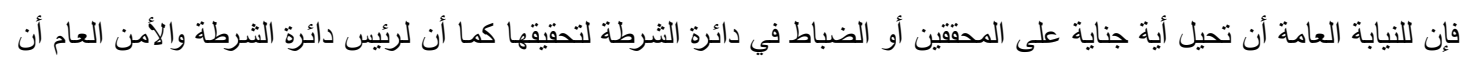

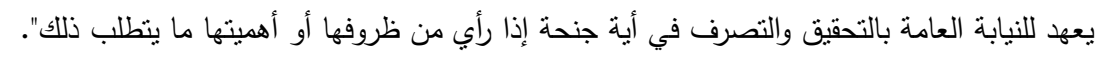
2- André Huet , Renée Koering,Joulin, Droit pénal international, Presses Universitaires de France in Paris, 2005,p327.

3-د. أمين عبد الرحمن محمود عباس،الإنابة القضائية،رسالة دكتوراهكلية الحقوق،جامعة الاسكندرية،سنة 2011،ص 238. 
ويخلط أنصـاره بين الإنابة القضـائية الدوليـة وبعض الإجراءات التي تتم عن طريق

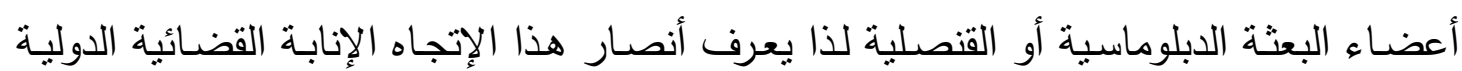

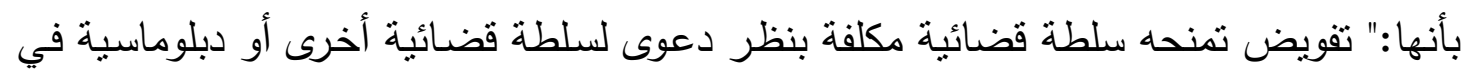

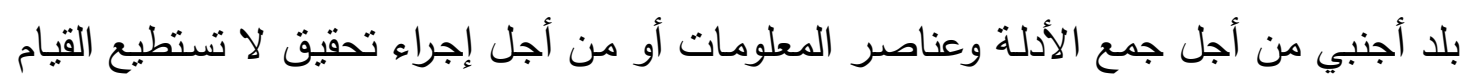

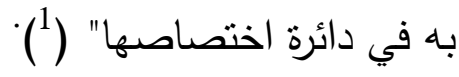
كمـا تعرف الإنابـة القضـائية الدوليـة في ضـوء هذا الإتجـاه بأنها" طلب مـن السلطة

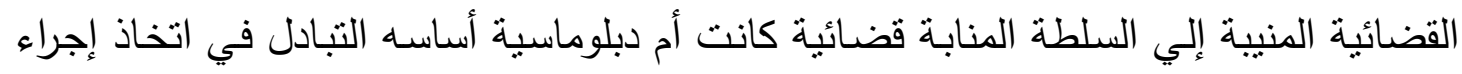

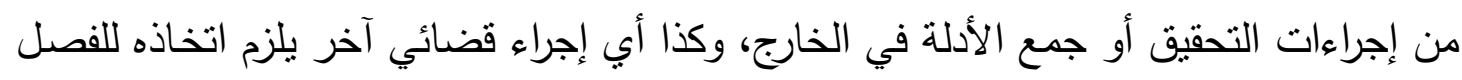

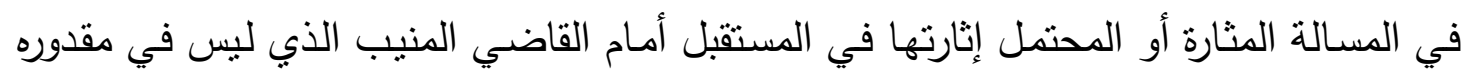

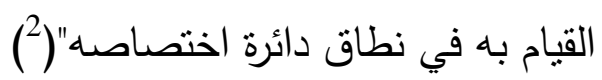
مآخذ على التعريفات المتقدمة: إن الذي يتأمل التعريفات المتقدمة يلاحظ أنها تنص على أنى أن الإنابة القضائية الدولية

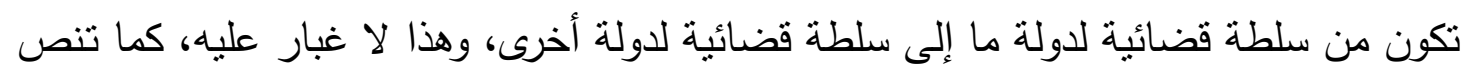

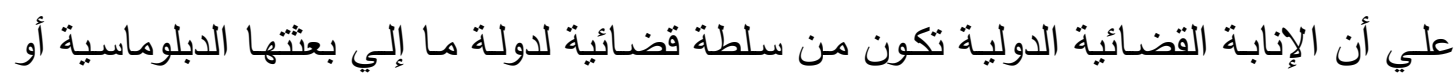

$$
\text { القنصلية في بلد أجنبي. }
$$

وفي هذا الجانب من التعريف يتم الخلط بين الإنابة القضائية الدولية والتي تكون من

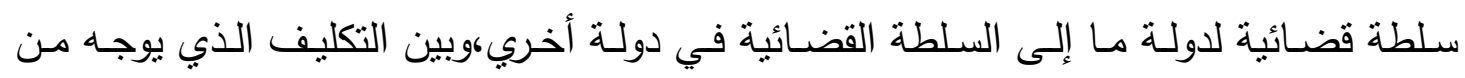

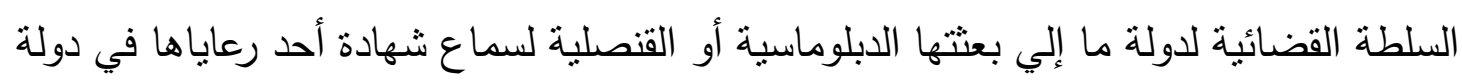

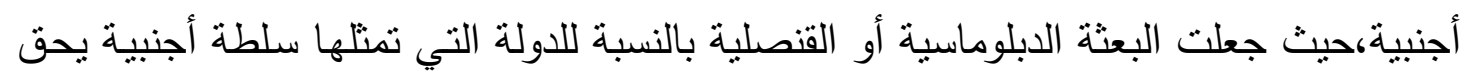
لها مباشرةً إجراء من إجراءات التحقيق على أرض دولة أخرى أجنبية.

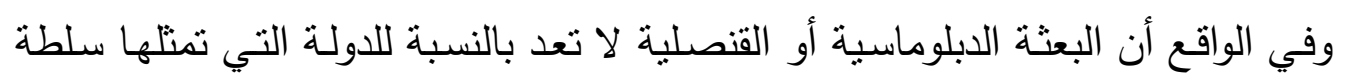

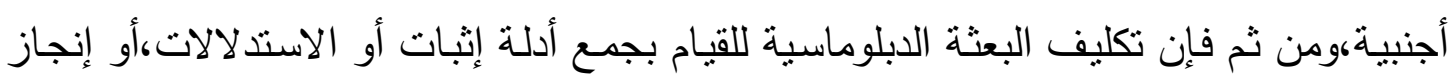

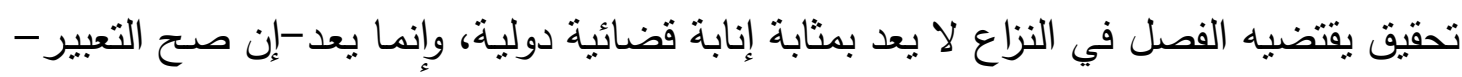

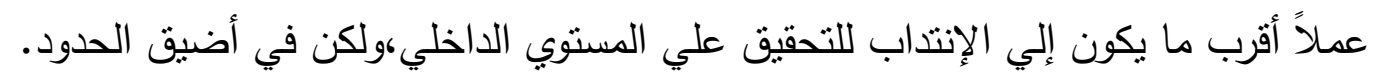

1- André Huet, Les conflits de lois en matière de preuve, Paris, Dalloz,1965,p.348

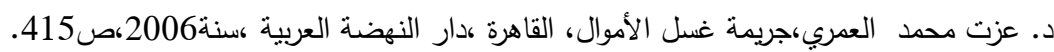

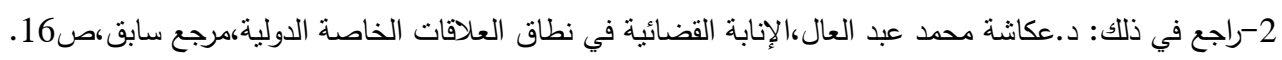

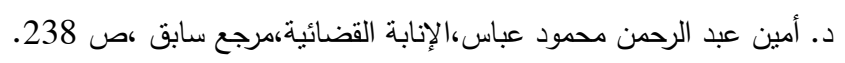


انطلاقاً مما تقدم يعرف الباحث الإنابـة القضـائية الدولية على أنها:"طلب موجها من

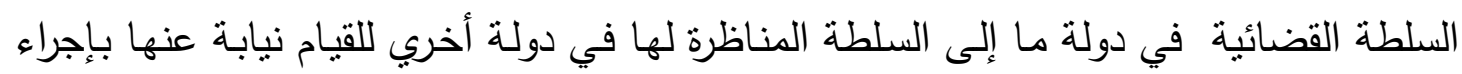

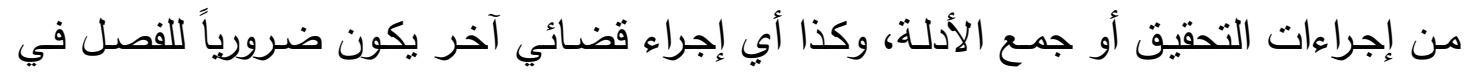

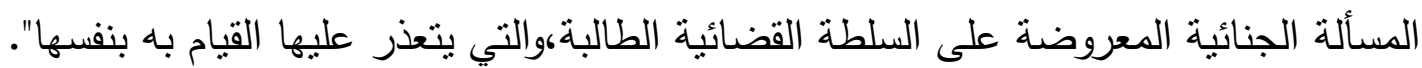
ثانيا-التمييز بين الإنابة القضائية الدولية وما قد يختلط بها من مصطلحات: يوجد بعض المصطلحات التي قد تخنلط بمصطلح الإنابة القضائية الدولية أو تتداخل

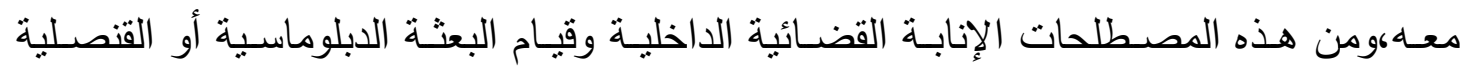
ببعض إجراءات التحقيق وسنتاول ذلك على النحو النالي: أ-التمييز بين الإنابة القضائية الدولية والإنابة القضائية الداخلية:

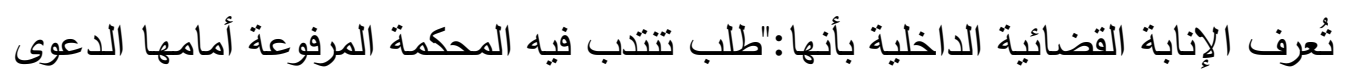

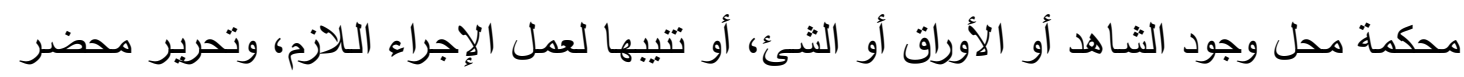

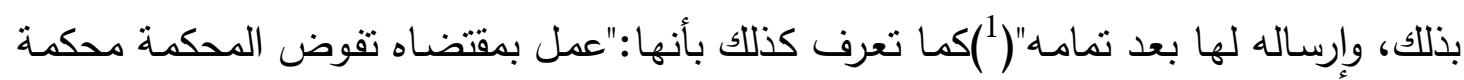

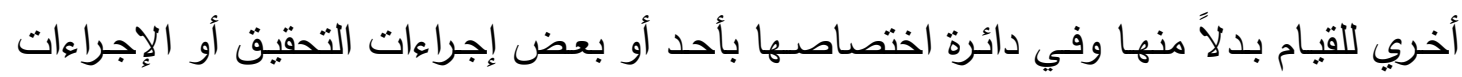

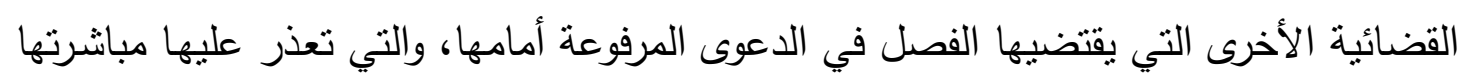
بنفسها بسبب بعد المسافة أو أي مانع آخر "(أ).

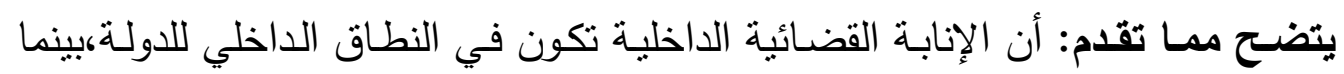

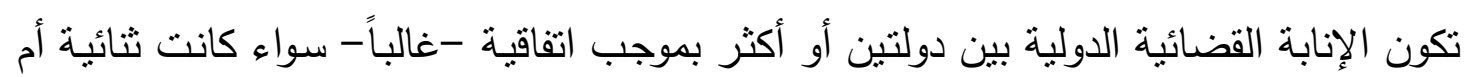

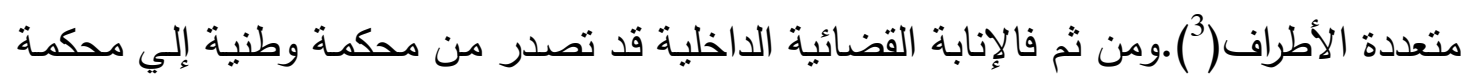

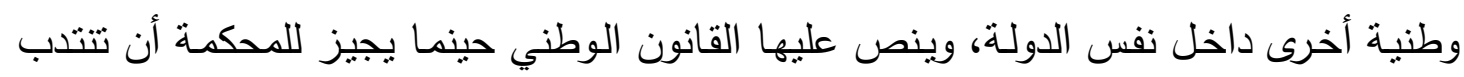

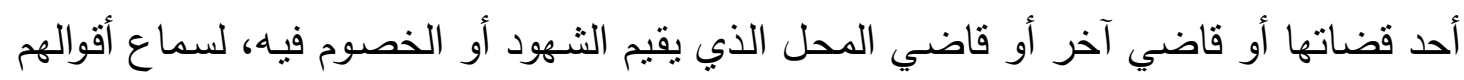

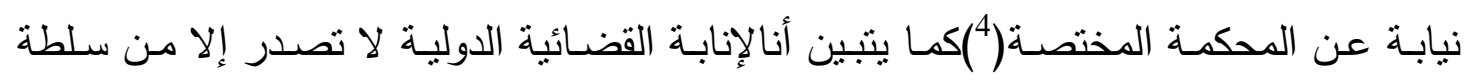

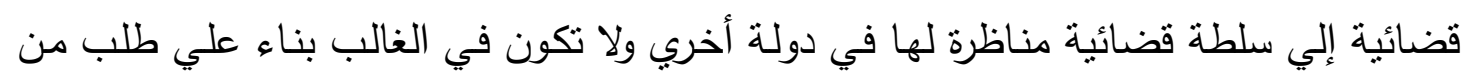

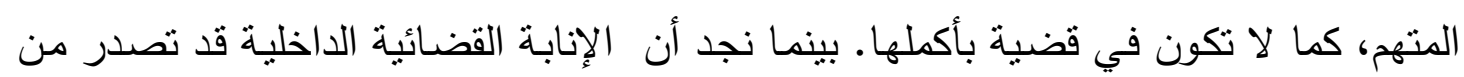

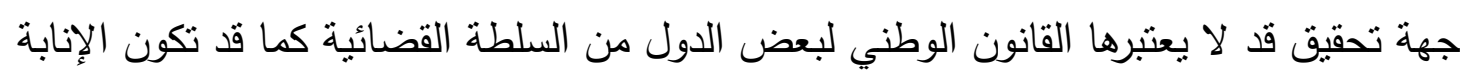

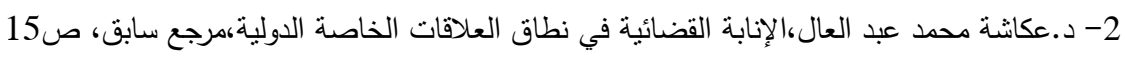

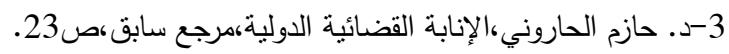

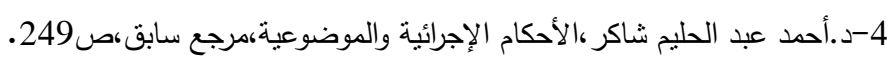


القضائية الداخلية بناء علي طلب من المتهم(1) وتكون الإنابة القضائية الداخلية للقيام بإجراء أو

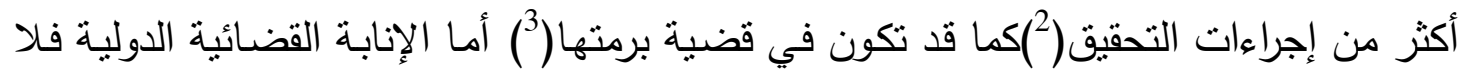
تكون في قضية بأكملها.

كما يتضح أن الإنابة القضائية الداخلية قد تكون من سلطة عليا إلى سلطة أدنى منها

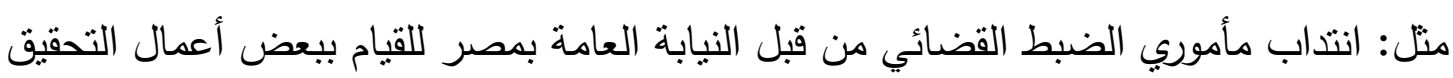
فهنا يكون للنيابة العامة الرئاسة والإشراف عليهم ومثل انتداب رئيس محكمة لأحد قضاة التحقيق

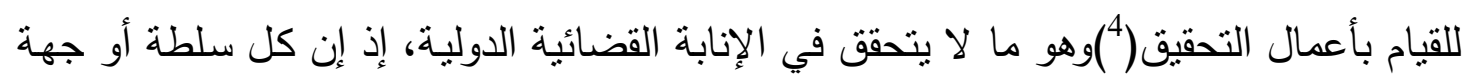
قضائية في كل دولة لا تخضع لغيرها من الدول الأخرى.

كما يتبين أخيراً أنه يكون للمحكمة الطالبة في الإنابة القضائية الداخلية سلطة الرقابة

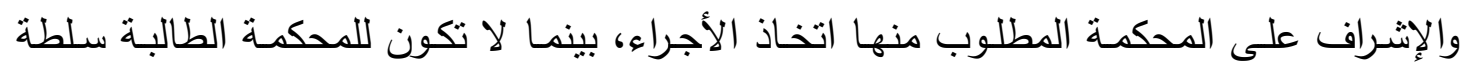

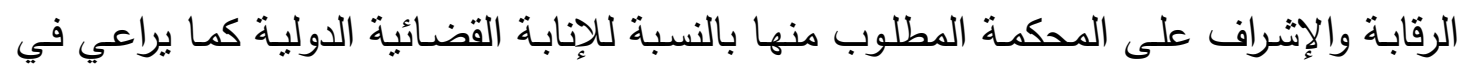

1-راجع المادة (64) من قانون الإجراءات الجنائية المصري والتي تتص علي أنه:"....... ويجوز للمتهه ....أن يطلب من رئيس المكمة الابتدائية إصدار قرار بهذا الندب".

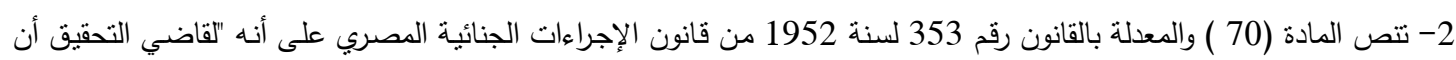

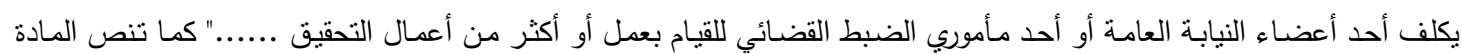

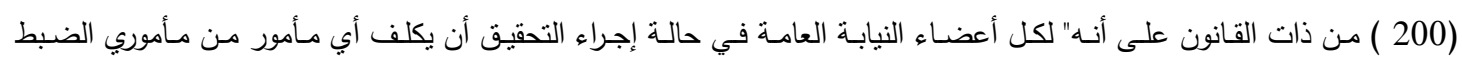
القضائي ببعض الأعمال التي من خصائصده". وتتص المادة( 75) من قانون الإجراءات الجزائية العُماني على أنه " لعضو الادعاء العام ألعام أن يكلف أحد مأموري الضبط القضائي القيام

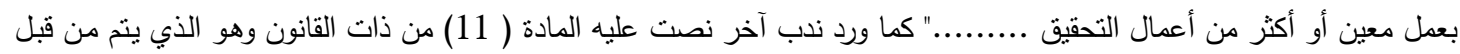

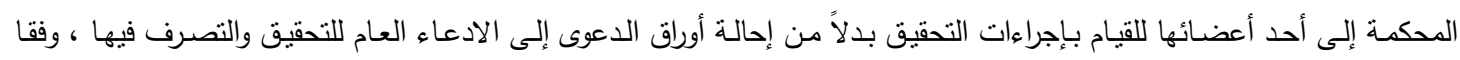
للحالات التي نصت عليها نلك المادة . 3-راجع في ذات المعنى: د. ناينتي ناين أحمد الدسوقي، تكليف مأمور ضبط قضائي بمباشرة إجراء تحقيق في النشريع المصري

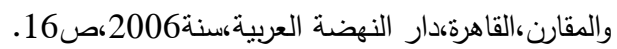
4-راجع في ذات المعنى:د.محمد عبد القادر العبودي، ندب مأمور الضبط القضائي لأعمال التحقيق،القاهرة، دار النهضة

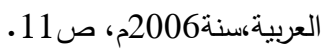


الإنابـة القضـائية الداخليـة ترتيب المحاكم ودرجاتها، فضـلاً عن إلزامها للقاضـي المطلوب منـه تتفيذها ما دامت تذخل في اختصاصه (1) ب-التمييز بين الإنابة القضائية الدولية وقيام البعثة الدبلوماسية أو القتصلية ببعض إجراءات التحقيق: قد يخلط البعض بين الإنابة القضائية الدولية الصادرة بواسطة السلطات القضائية للدولة مع تلك التي تنت عن طريق أعضاء السلك الدبلوماسي أو القنصلي من أجل سماع شهادة أحد رعاياها في واقعة محددة، فقد يحدث أن ترتكب جريمة في دولة ما ويكون من بين الثهود على هذه الجريمة شخص من رعاياها، ولكنه يقيم بصفة دائمة أو مؤقتة في إقليم دولة أخرى، ويتعذر لهر حضـور هذا الثـاهد إلى دولتهـ لـلإِدلاء بثـهادته، وفي مثنل هذه الحـالات قد تقضـل السـلطة القضائية في هذه الدولة اللجوء إلى البعثة الدبلوماسية أو القنصلية الموجودة في الخارج لسماع شهادة هذا الثخص وتذوينها، وإحالتها بعد ذلك إلى السلطة القضائية التي انتدبتها لذلك. حيث قد يعتبر البعض أن هذا الإجراء الذي تم بمعرفة أعضـاء السلك الدبلوماسـي أو القنصلي هو من قبيل الإنابة القضائية الدولية. يذهب بعض الفقه إلي أن هذا الإجراء الذي تم بمعرفة أعضاء السلك الدبلوماسي أو

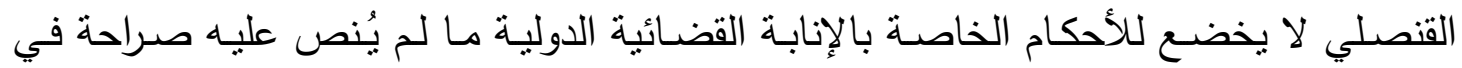
بعض الاتفاقيات الدولية(2)،ويفهم من هذا الكلام أنه إذا نصت بعض الاتفاقيات الدولية(3) علي هذا الإجراء فإنه يعتبر حينئذ بمثابة إنابة قضائية دولية. أما إذا لم ينص عليه صراحة من خلال بعض الاتفاقيات الدولية فإنه لا يعد كذلك.

1-د.بدر الدين عبد المنعم شوقي،الإنابة القضائية العربية في المسائل الجنائية،مرجع سابق،ص28.

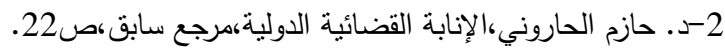
3-وذلك مثل اتفاقية التعاون القانوني والقضائي بين مصر والإمارات والتي اعتبرت هذه الإجراءات من قبيل الإناتئ الإنابة القضائية،حيث

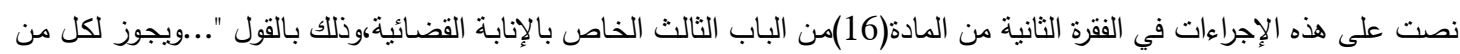

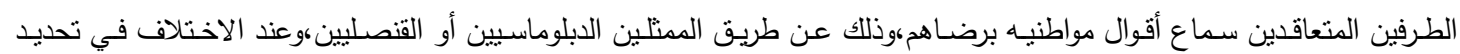

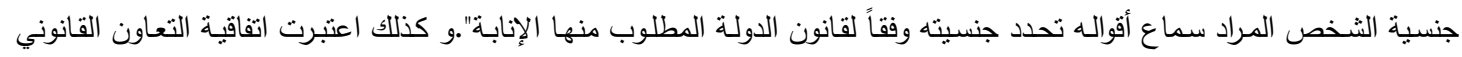

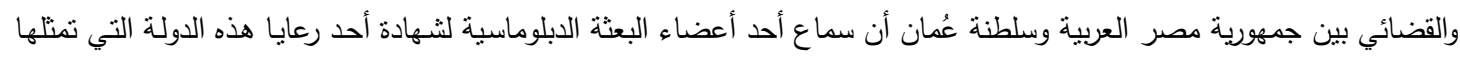

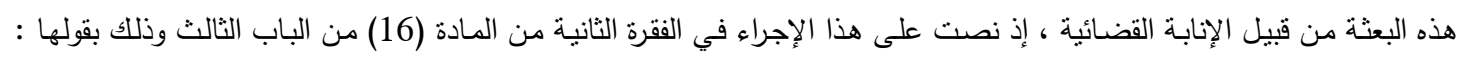

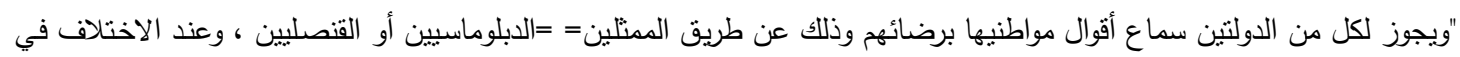

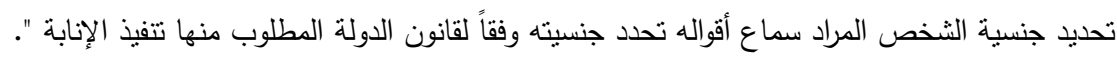

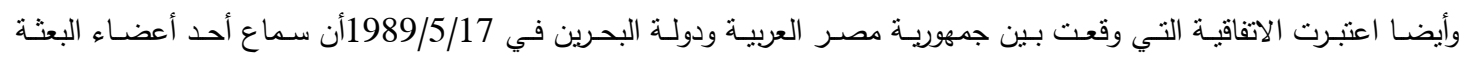

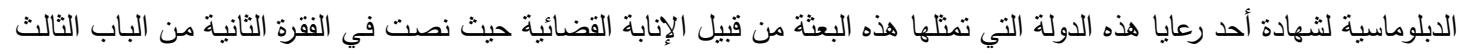

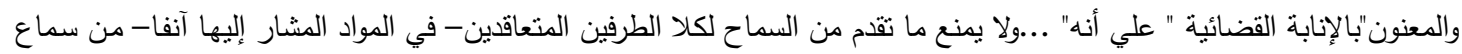

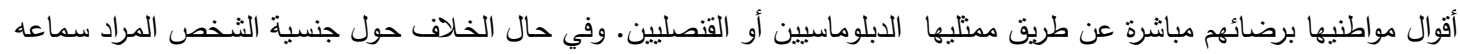

تحدد جنسيته وفق قانون الدولة المطلوب منها تنفيذ الإنابة فيها". 


\section{المطلب الثاني \\ الأساس القانوني للإنابة القضائية الدولية}

يقصد بالأساس القانوني تحديد النصوص القانونية التي يستند اليها هذا النظام سواء تمثلت في اتفاقيات دولية أو نصوص دستورية أو عادية.(1) وتستتد الإنابة القضائية الدولية إلى الاتفاقيات الدولية،سواء كاديهاء كانت هذه الاتفاقيات ثنائية

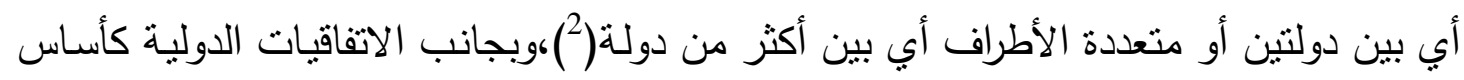
قانوني للإنابة القضائية الدولية،تركن بعض الدول إلى إلى قانونها الوطني، لنتظيم الإنابة القضائية

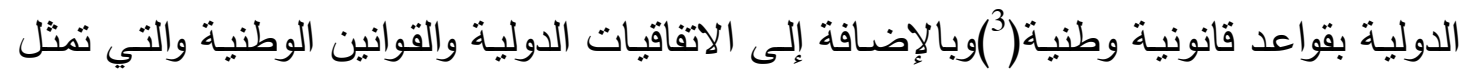

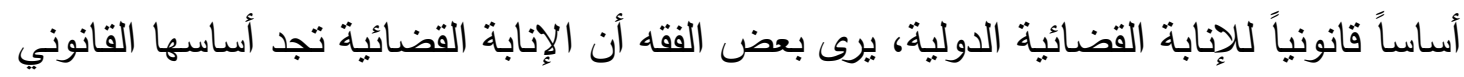

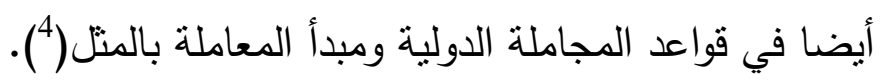
وسوف نعرض للإتفاقيات الدولية كأساس قانوني للإنابة القضائية الدولية وذلك على بلى لكاعلى

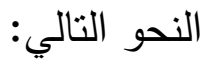

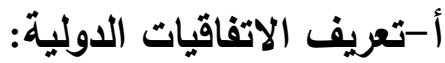

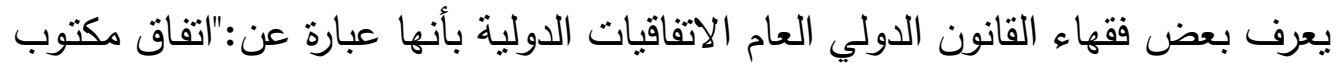

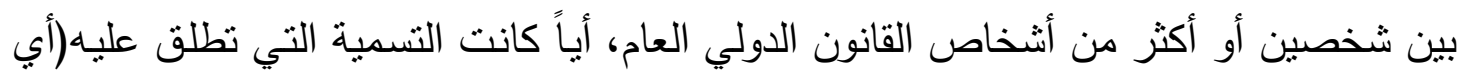

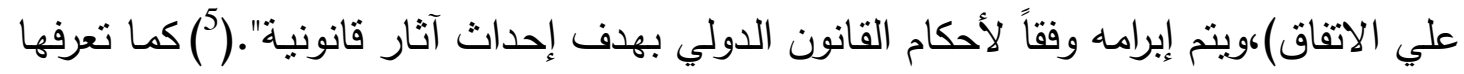

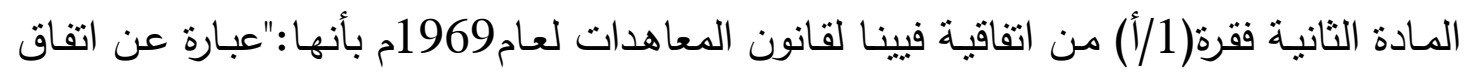

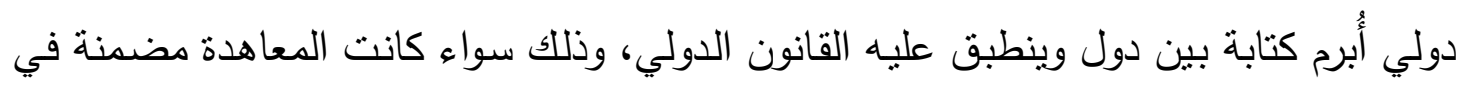

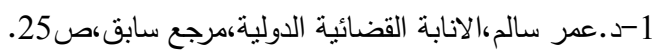

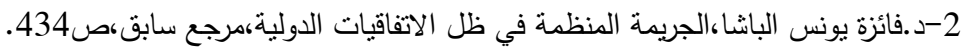
3- د.أحمد إبراهيم مصطفى سليمان،العلاقة بين الإرهاب والجريمة المنظمة وسبل المواجهة،رسالة دكتوراه،أكاديمية الشرطة،كلية

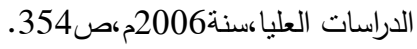
4-د.أحمد عبد الحليم شاكر ،الأحكام الإجرائية والموضوعية للمعاهدات،مرجع سابق،صالص253. 5-د.عبد العليم عبد المجيد مشرف،الرقابة على دستورية المعاهدات الدولية،دراسة مقارنة، القاهرة، دار النهضية

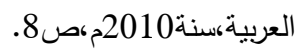


وثثقة واحدة أو في وثثقتين أو عدة وثائق مرتبطة ببعضها، ومهما كانت التسمية الخاصة المطلقة

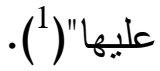

\section{ب - أنواع الاتفاقيات الدولية:}

يقسم فقهـاء القـانون الدولي الاتفاقيات الدوليـة مـن الناحيـة الثنكلية تبعـاً لعدد الدول

$$
\text { الأطراف في الاتفاقية إلى: - القى }
$$

- - اتفاقيات جماعية:وهي التي تبرم بين ثلاثة من أثخاص القانيه إلتون الدولي علي الأقل.

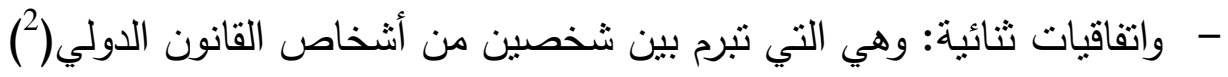

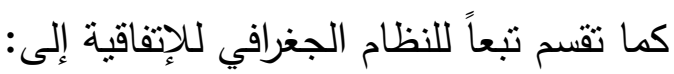

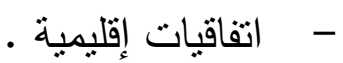

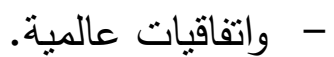

- - كما تقسم تبعاً لصفة المتعاقدين إلى: -

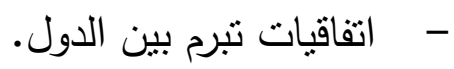

- - واتفاقيات تبرم بين الدول والمنظمات الدولية.

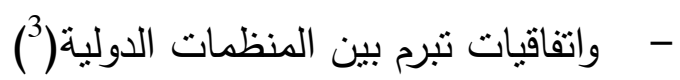

كما يقسم فقهاء القانون الدولي الاتفاقيات الدولية من حيث الموضئ المبوع، أي من حيث

فحوى الاتفاقية الدولية إلي:

- الاتفاقيات الدولية ذات الطابع التعاقدي وهي الاتفاقيات التي تتظم علاقات معينة بين أطرافها، كالتعاون القضائي أو التبادل التجاري......الخ.

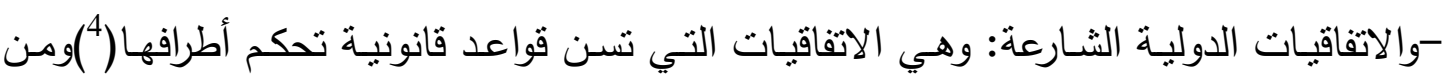
أمتلتها المعاهدات التي تقنن قواعد القانون الدولي كاتفاقية إبادة الجنس لعام 1948، واتفاقية

1-"treaty" means an international agreement concluded between States in written form and governed by international law, whether embodied in a single instrument or in two or more related instruments and whatever its particular designation"

$$
\begin{aligned}
& \text { 2- د.أحمد أبو الوفا،الوسيط في القانون الدولي العام، القاهرة، دار النهضة العربية، سنة2007م، ص78 }
\end{aligned}
$$

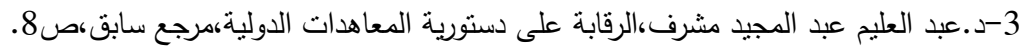

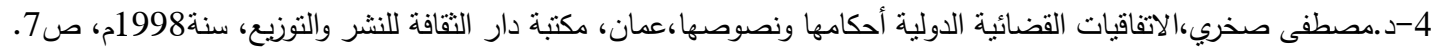


فيينا الخاصـة بالعلاقات الدبلوماسية عام 1961 واتفاقية فيينا الخاصة بالمعاهدات الدولية لعام 1996 1960

\section{ج-الإنابة القضائية في الاتفاقيات الدولية:}

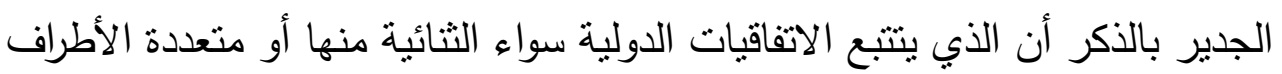

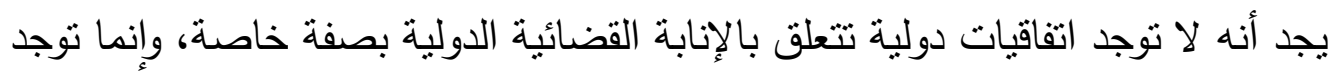
اتفاقيات عامة نأخذ مسميات عديدة تتضمن بين بنودها مواد تتعلق بالإنابة القضائية وذلك

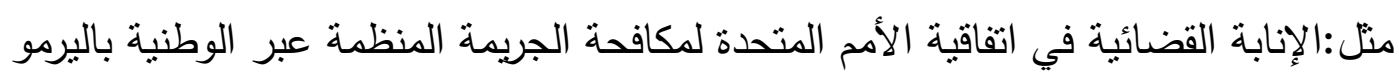

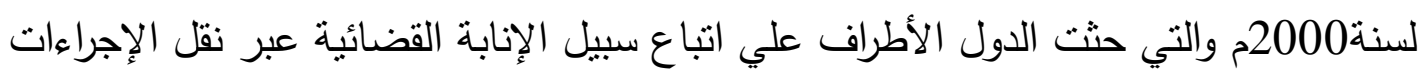

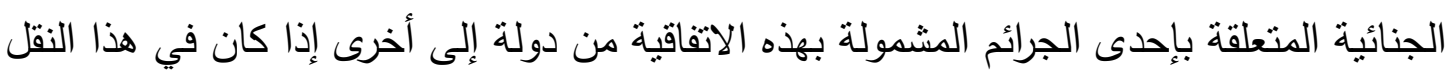

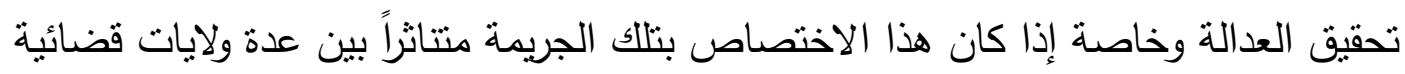

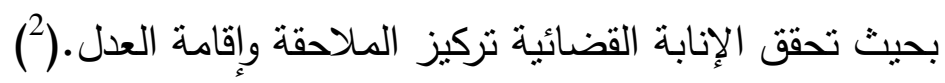

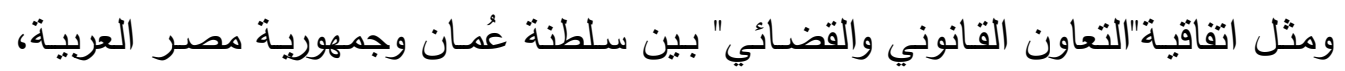

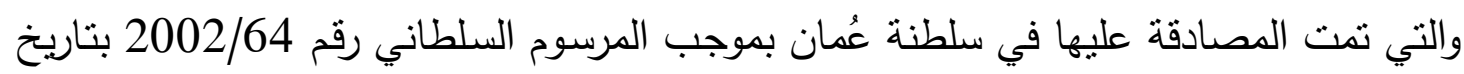
27 يوليو 2002،وتم نشـرها في العدد رقم 723 من الجريدة الرسمية،ونظمت أحكام الإنابـة

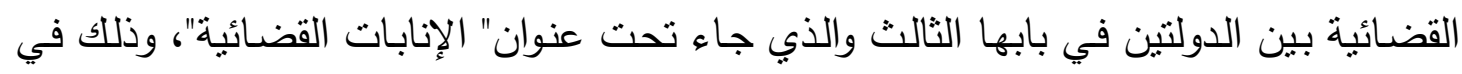
المواد من ( 15-22).

ومثل اتفاقية الرياض العربية"للتعاون القضائي" الموقعة عام 1983 بين مجموعة من

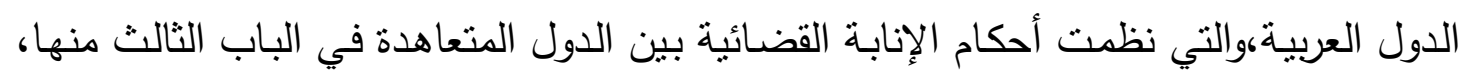

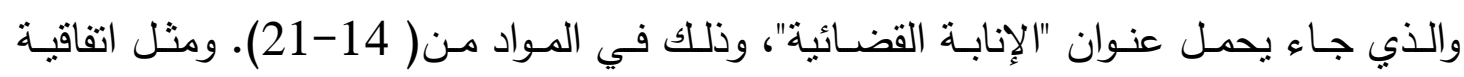

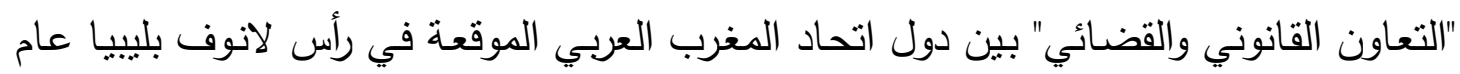

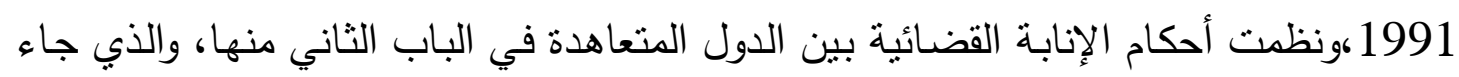
تحت عنوان"الإنابات القضائية" في المواد من (19- 26 ).

1- اللمزيد من المعلومات حول هذه المعاهدات راجع في ذلك:

Richard Crawford Pugh,Oscar Schachter, Hans Smit, Louis Henkin, International Law: Cases and Materials, West Publishing Co., 2001.p81...ets

2-المادة(21) من اتفاقية الأمم المتحدة لمكافحة الجريمة المنظمة عبر الوطنية والتي تتص على أنه:" تنظر الدول الأطراف في

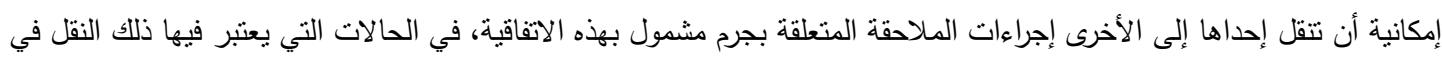
صالح سلامة إقامة العدل، وخصوصا عندما يتعلق الأمر بعدة ولايات قضائية، وذلك بهدف تركيز الملاحقة. 


\section{المطلب الثالث \\ أسباب طلب الإنابة ويياناته وتنفيذه}

\section{أولاًَ-أسباب طلب الإنابة القضائية:}

لقد حددت المعاهدة النموذجية للأمم المتحدة بشأن نقل الإجراءات في المسائل الجنائية الأسباب المؤدية إلى طلب الإنابة القضائية وحصرتها المادة الأولي من المعاهدة في حالة ما إذا اشتبه في أن شخصاً ما قد ارتكب فعلاً مؤثثاً وفقاً لقانون دولة طرف متعاقد فأجازت لتلك الدولة أن تطلب إلى دولة أخري طرف في المعاهدة أن تتخذ الإجراءات القضائية بخصوص هذه الجريمة إذا كان ذلك يحقق العدل على الوجه الأكمل('). ثانياً بيانات طلب الانابة وكيفية تقديمه: لقد أوجبت المعاهدة النموذجية للأمم المتحدة بشأن نقل الإجراءات في المسائل الجنائية على الدولة الطرف التي ترغب في نقل الاجراءات الجنائية إلى دولة أخرى أن نتقدم اليها بطلب كتابي مشوفعاً بالمستتدات والوثائق اللازمة ويكون تقديم طلب الانابة وما يليه من مكاتبات متبادلة وفقاً للطرق لدبلوماسية مباشرة بين وزارتي العدل في كل من الدولة الطالبة والأخرى المطلوب إليها أو بين أي سلطات أخرى يحددها الطرفان المعنيان(2). وينبغي أن يتضمن طلب الإنابة القضائية البيانات النالية:

-البيان المتعلق بالسلطة أو الجهة مقدمة الطلب -وصف الواقعة المطلوب الإنابة القضائية بشأنها وما يتصل بهذه الواقعة من بيانات لازمة لاتخاذ الإجراءات على نحو يحقق العدالة. -النصوص القانونية في تشريع الدولة الطالبة والتي يعد الفعل الطلوب نقل الإجراءات بشأنه مؤثماً وفقاً لها. -خلاصة التحريات التي أجريت والتي نؤكد الإشتباه في تورط المشتبه به في الجريمة. -معلومات كافية عن هوية المتهم أو المشتبه فيه.

1-تنص المادة الاولى من المعاهدة النموذجية بشأن نقل الإجراءات في المسائل الجنائية على انه:" إذا اثتبه في أن شخصا ما قد

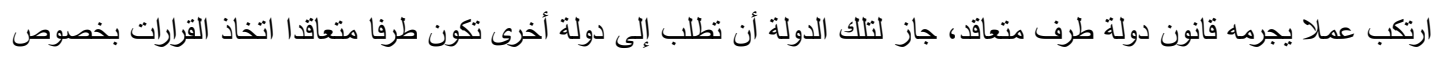

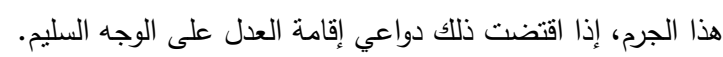

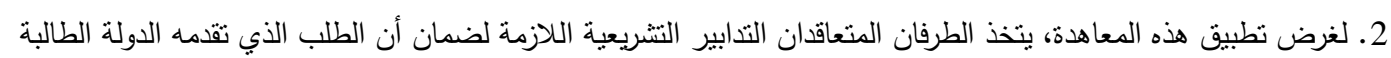
لاتخاذ إجراءات سوف يمكن الدولة المطالبة من ممارسة الولاية القضائية الضرورية.

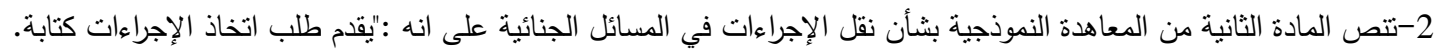

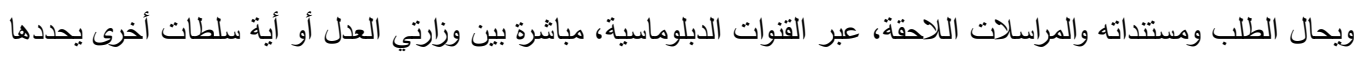
الطرفان. 
ويرفق بالطلب ترجمة له بلغة الدولة المطلوب اليها أو بأية لغة أخرى يتم الاتفاق عليها وكذلك ترجمة لجميع الوثائق المرفقة بالطلب (1). ثالثا-ضوابط تنفيذ طلب الإنابة القضائية:

عند تلقي الدولة الطرف لطلب الإنابة من الدولة الطالبة يتعين عليها المبادرة إلى الاستجابة له وتتفيذه وفقاً لقانونها الداخلي(2) مع مراعاة ما يلي: -إخطار الدولة الطالبة بما يتم اتخاذه من قرارات بشأن تتفيذ طلب الإنابة. -عدم المساس بحقوق المجني عليهم بأي صورة كانت نتيجة لنقل الإجراءات إلى الدولة المطلوب إليها بموجب طلب الإنابة(3).

-في حالة إقامة الدعوي الجنائية في الدولة المطلوب إليها،يتعين علي الدولة الطالبة أن توقف السير في أيه دعوى أخري تكون قد أقامتها عن ذات الجريمة التي أقيمت الدعوى بثأنها في الدولة الأخرى الطرف التي طلب إليها اتخاذ الإجراءات الجنائية بطريق الإنابة وإذا قضت الدولة

1-تتص المادة الثالثة من المعاهدة النموذجية بثأن نقل الإجراءات في المسائل الجنائية على أنه:" يتضمن طلب اتخاذ الإجراءات

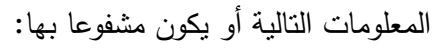

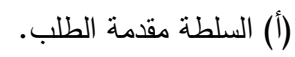

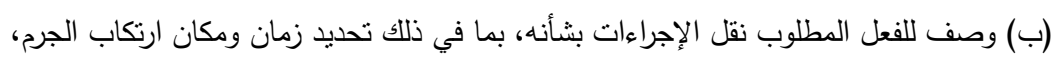

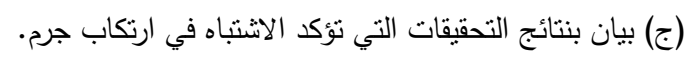

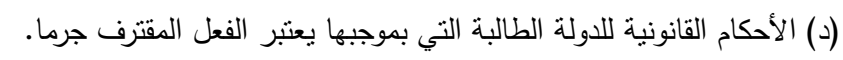
(ه) معلومات دقيقة بقدر معقول عن هوية المشتبه فيه وجنسيته ومحل إقامته.

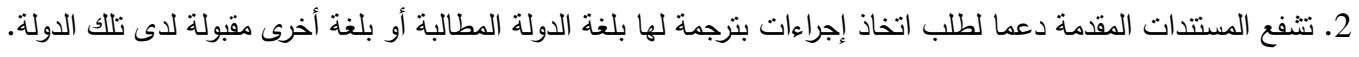

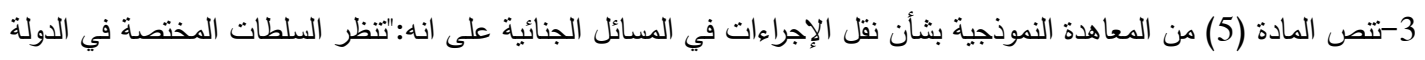

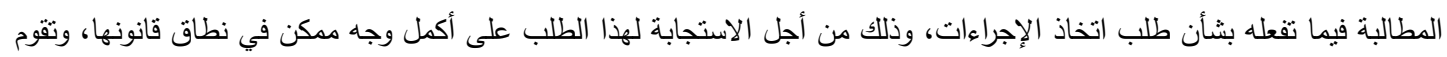

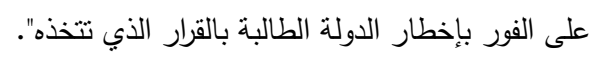

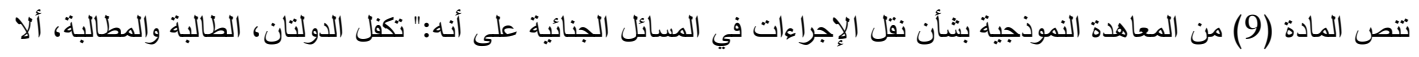

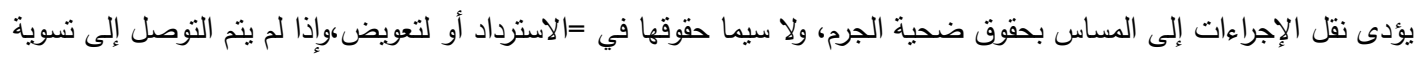

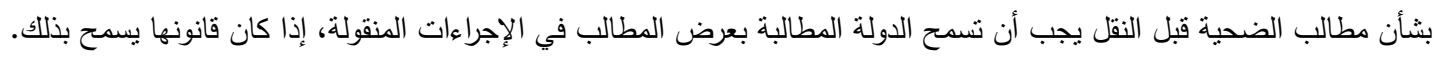
وفي حالة وفاة الضحية يسرى هذا الحكم بالنالي على معاليها. 
المطلوب إليها في الدعوى فإنه بصدور هذا الحكم يمتتع عن الدولة الطالبة نهائياً السير في

$$
\text { الدعوى التي كانت مرفوعة لديها عن نفس الجريمة(1). }
$$

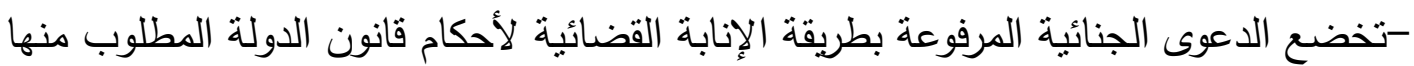

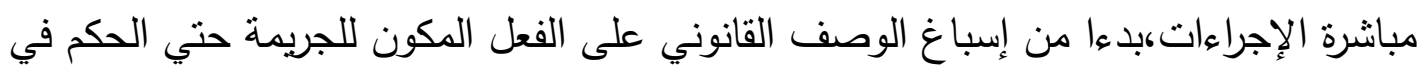

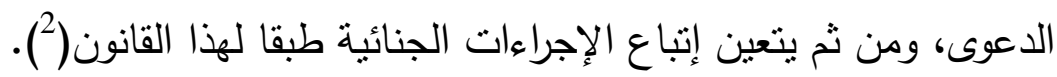
ولا يجوز الحكم في الدعوى المرفوعة في الدولة المطلوبة اليها بأثند العقوبة المقررة للجريمة في الدولة الطالبة(3). - يجوز للدولة المطلوب إليها إقامة الدعوى- بناء على طلب الدولة الطالبة- أن تتخذ جميع

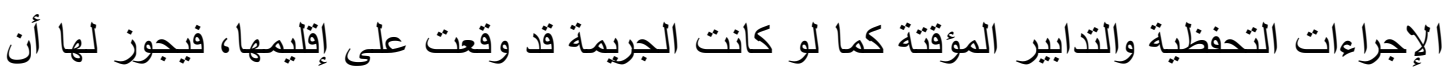

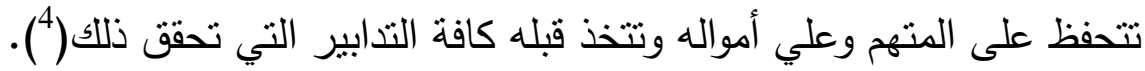

1-تتص المادة(10)من المعاهدة النموذجية بشأن نقل الإجراءات في المسائل الجنائية على أنه:" متى قبلت الدولة المطالبة طلب اتخاذ

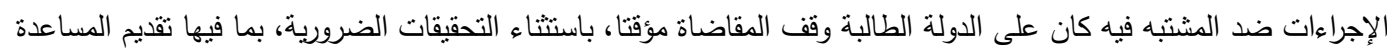

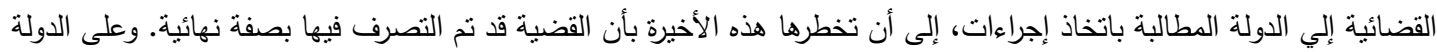

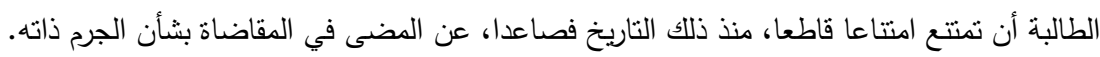
2-تنص المادة(11/1)من المعاهدة النموذجية بثأن نقل الإجراءات في المسائل الجنائية على أنه:" تخضع الإجراءاءت الماتهات المنقولة بناء

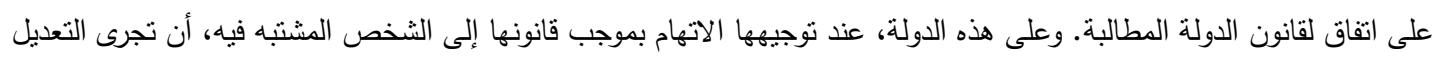

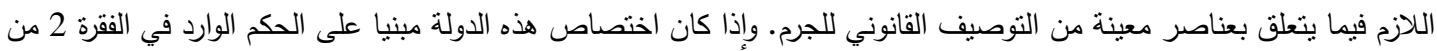

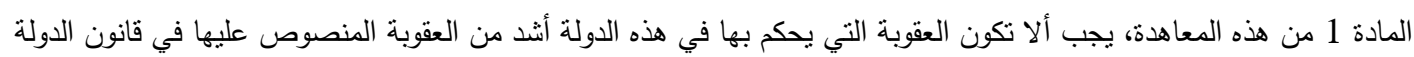
الطالبة.

3-تنص المادة(2/11)من المعاهدة النموذجية بثأن نقل الإجراءات في المسائل الجنائية على أنه:"يكون لأي إجراء يتخذ في الدولة

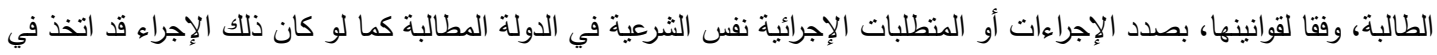

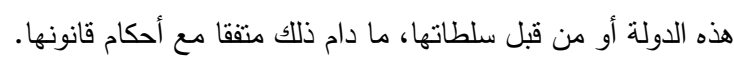

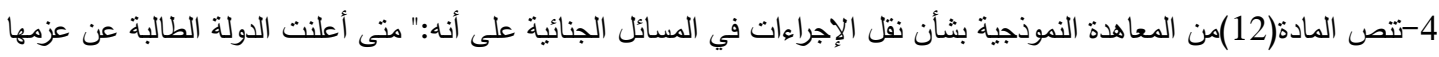

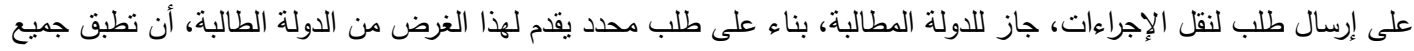

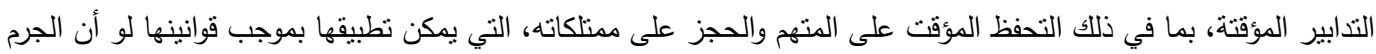
المطلوب نقل الإجراءات بصدده كان قد ارتكب في أراضيها. 


\section{المبحث الثاني \\ تسليم المجرمين}

\section{تمهِبِ وتقسبِي:}

يعد تسليم المجرمين من أبرز صور التعاون الدولي القضائي لمكافحة الجريمة المنظمة وأكثرها شيوعاً والسبب في ذلك يعود إلى طبيعته وأثزه المباشر في تحقيق أكبر قدر من الفاعلية للتعاون بين الدول فالتسليم يعبر عن رغبة صريحة للدول في تحقيق هذا التعاون وهو أسلوب تتهار به الحدود بين الدول التي يتخذها المجرمون دروعاً واقية للإفلات من العقاب.(( ) كما أن التسليم يمكن السلطات المختصة في الدولة الطالبة من وضع يدها على الشخص المطلوب إما لاتخاذ الإجراء ات الجنائية ضده لمحاكمته عن جريمة ارتكبها أو لتتفيذ حكم صادر ضده بعقوبة ومطلوب تتفيذه.(2) وفي ضوء ما تقدم وللتعرف على تسليم المجرمين سنقسم هذا المبحث إلى المطالب

المطلب الأول: مفهوم التسليم. المطلب الثاني: مبررات التسليم وخصائصه. المطلب الثالث: شروط التسليم. 


\section{المطلب الأول \\ مفهوم التسليم}

لقد تباينت تعريفات نسليم الجرمين في صياغتها ولكنها تلاقت في فحواها حيث يعرف البعض دله

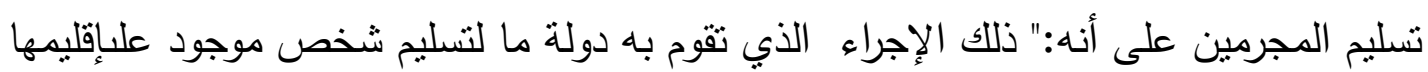

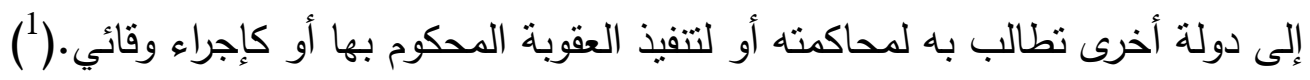

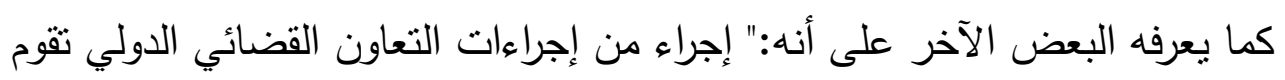

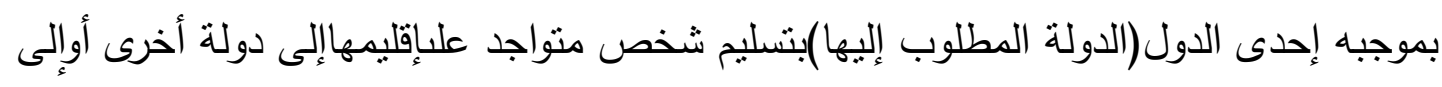

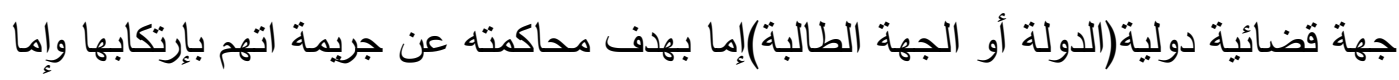
لأجل تتفيذ حكم الإدانة الصادر ضده من محاكم هذه الدولة أو الدحكمة الدولية.(2)

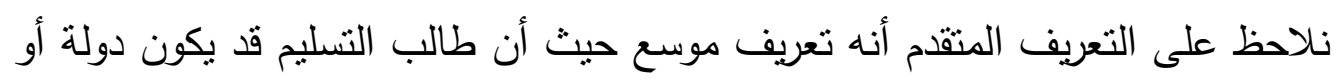

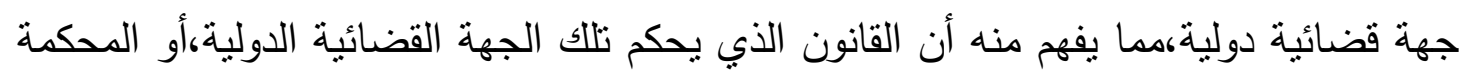
الدولية يمكن الإسترشاد به عند اتخاذ إجراءات التسليم.

وثمة من يعرف تسليم المجرمين بأنه:" نظام في علاقات الدول من مقتضاه النداه أن تقبل

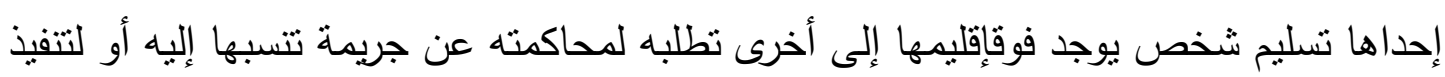

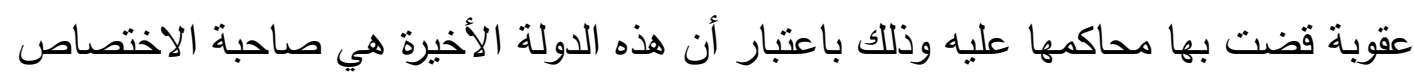
الطبيعي أو الأفضل في تلاك المحاكمة أو ذلك التنفيذ.(3)

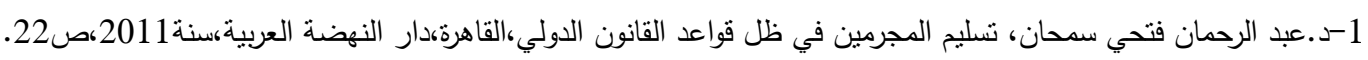

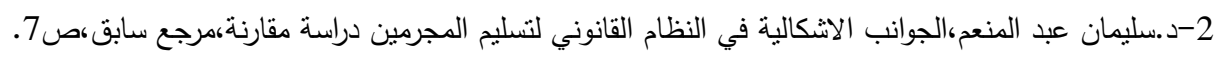

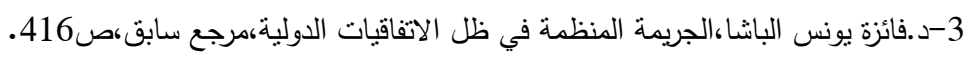


وتم تعريف التسليم على أنه:" إجراء نسلم بموجبه دولة استتاداً لمعاهدة أو تأسيساً علي المعاملة

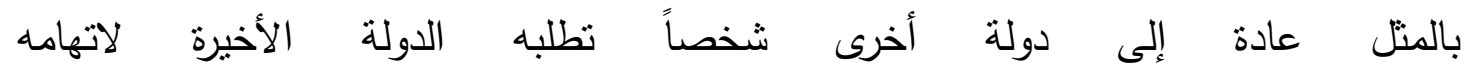

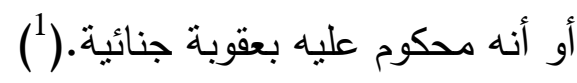

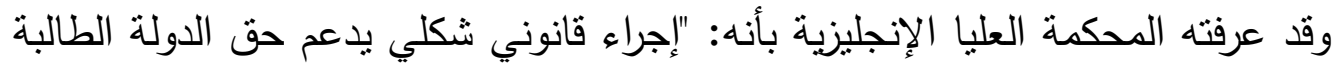

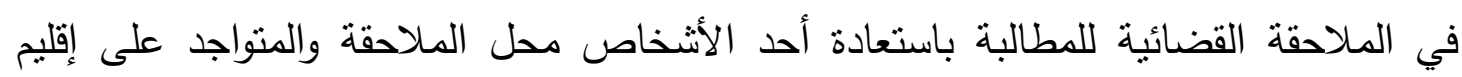

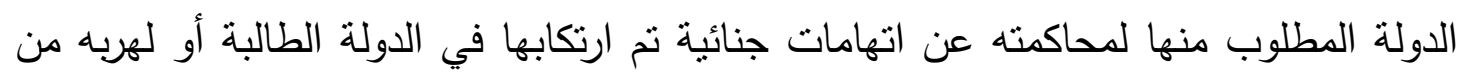
الحبس القانوني المحكوم عليه في الدولة الطالبة.(2) كما عرفته المحكمة العليا الأمريكية على أنه:" الإجراء القانوني المؤسس على على معاهدة أو

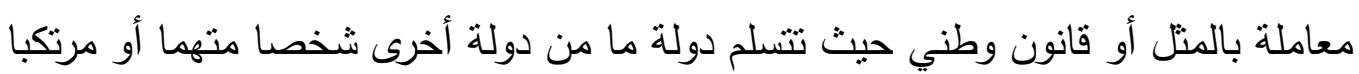
لمخالفة جنائية ضد القوانين الخاصة بالدولة الطالبة

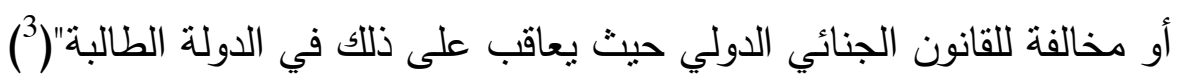

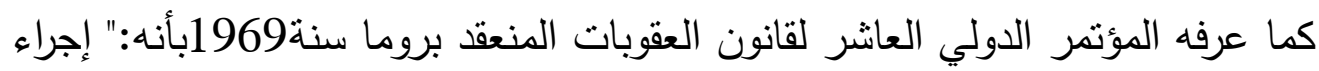

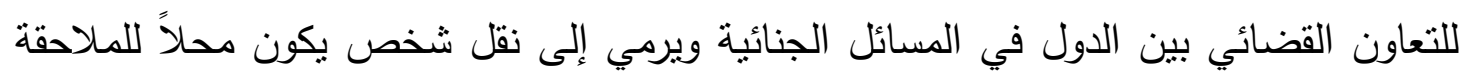

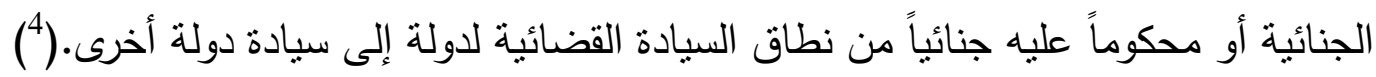

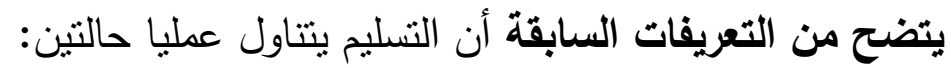

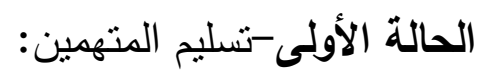

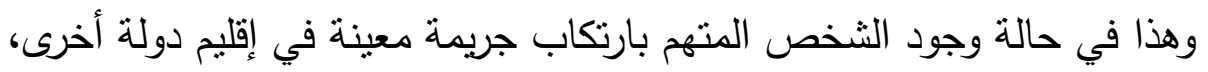
ومطالبة الدولة التي ينعقد لها الإختصاص بمحاكمته من الدولة المنواجد على إقليمها بتسليمه لها لاتخاذ إجراءات التحقيق أو محاكته عن الجريمة المنسوبة إليه. الحالة الثانية-تسليم المحكوم عليهم: وذللك بأن يصدر حكم بالإدانة من محكمة مختصة في الدولة الطالبة على شخص وقبل تتفيذ العقوبة عليه يفر إلى إقليم دولة أخرى فترسل الدولة الطالبة إلى الدولة المنواجد على على لداني إقليمها الددان وهي الدولة المطلوب منها من أجل تتفيذ العقوبة عليه. 


\section{المطلب الثاني \\ مبررات التسليم وخصائصه}

أولاًَمبررات التسليم:

تتمحور أهم مبررات تسليم المجرمين في عدة اعتبارات تتمنل فيما يلي:

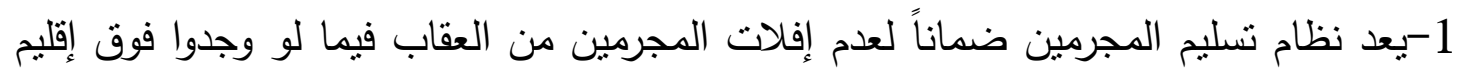

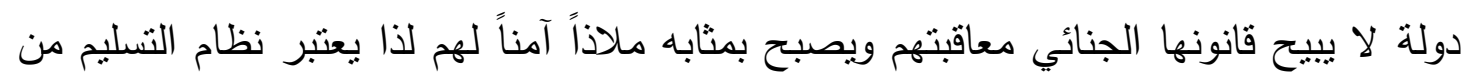

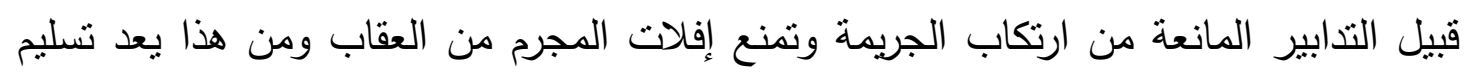

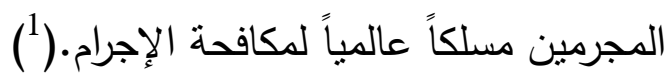

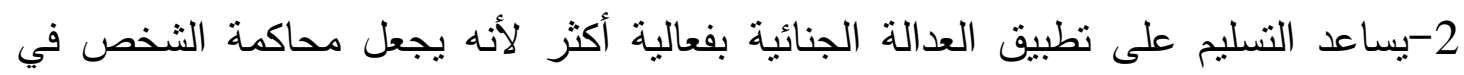

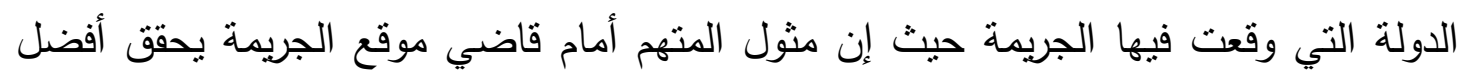

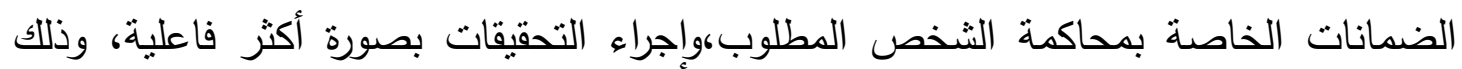
بخلاف ما إذا تمت تلاك الإجراءات بعيداً عن موقع اقتراف الجريمة.(2)

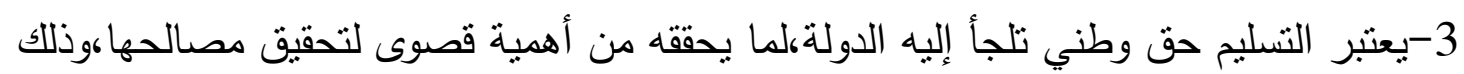

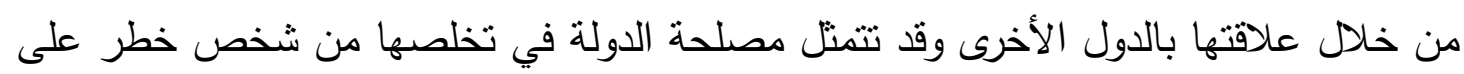

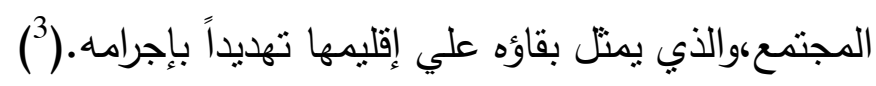

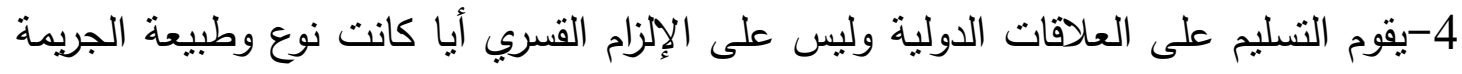

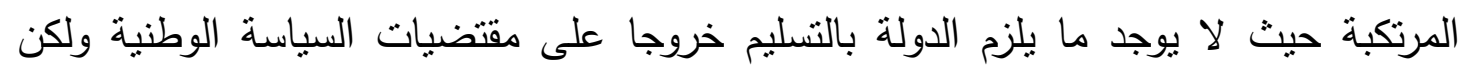

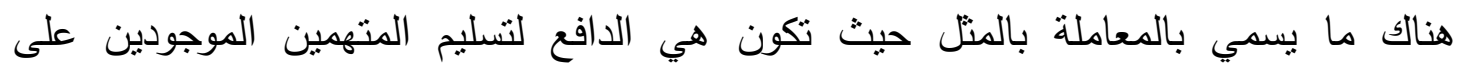

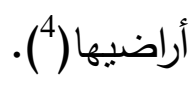
ثانياً-خصائص التسليم: أنئ

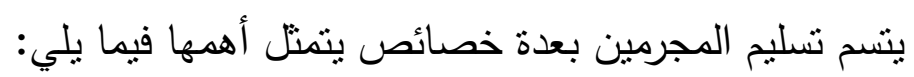

1-د.حسنين عبيد،التعاون الدولي في مكافحة الجريمة،مجلة القانون والاقتصاد للبحوث القانونية والاقتصادية،س33،سنة

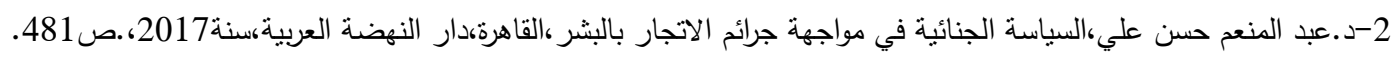

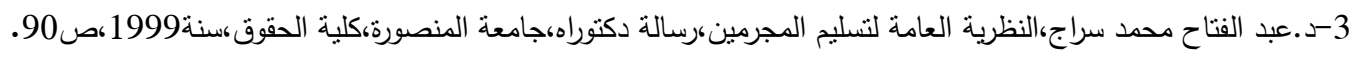

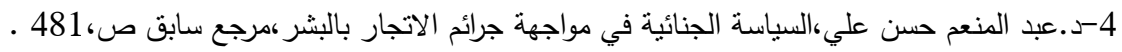


التسليم عبارة عن إجراء أبي أنه فكرة اجرائية تتتمي إلى أفكار قانون الإجراءات الجنائية ولعل أهم نتيجة نترتب على ذلك وجوب اعتبار القواعد المنظمة للنسليم هي قواعد إجرائية

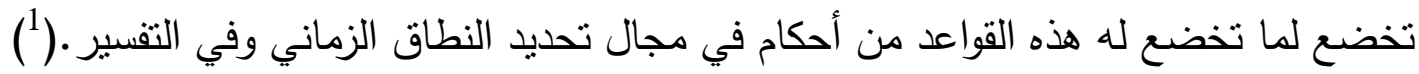

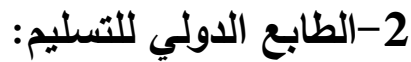

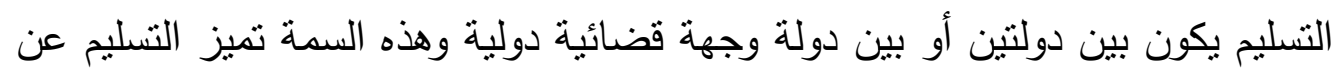
غيره من الإجراءات القضائية التي تتم داخل إقليم الدولة الواحدة وهذا الطابع الدولي للتسليم يمكن

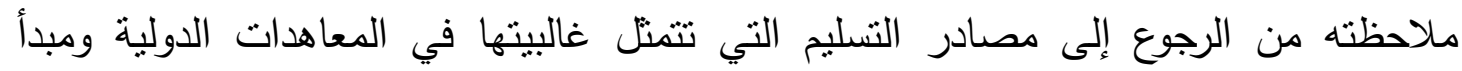

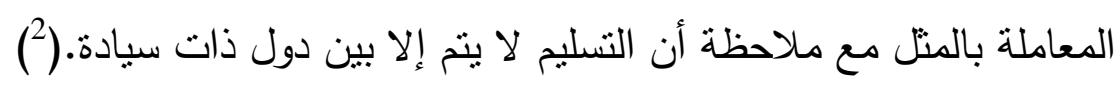

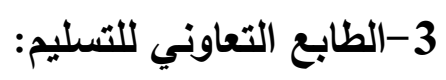

التسليم إجراء طوعي ينطلق من فلسفة التعاون القضائي بين الدول لمكافحة الجريمة وملاحقة المجرمين أينما كانوا فقواعده ليست بنفس درجة الإلزام التي تتمتع بهاء القواعد القانونية

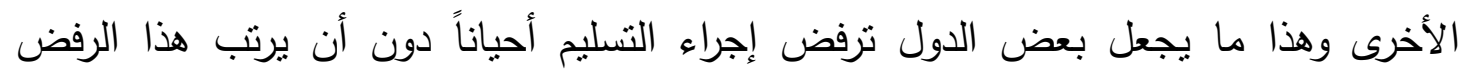

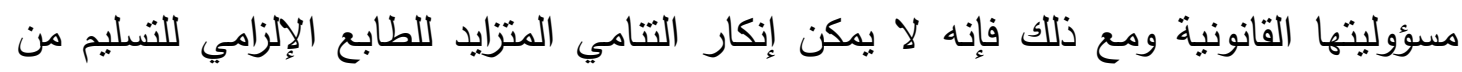

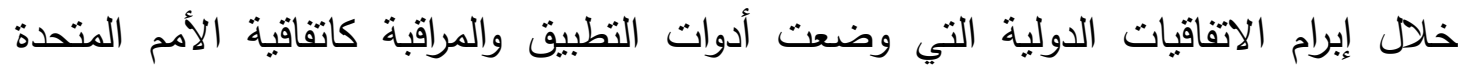
لمكافحة الجريمة المنظمة(اتفاقية باليرمو 2000)التي خصصت التصات المادة(16) منها لتسليم

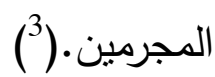

4-ابطع العالمي للتسليم:

يتسم التسليم بطابع عالمي يعكس المفاهيم العالمية المشتركة التي تأخذ بها أكثرية دول العالم في العصر الحالي والمرتبطة بحقوق الإنسان ومن ذلك امتتاع التسليم في الجرائم السياسية

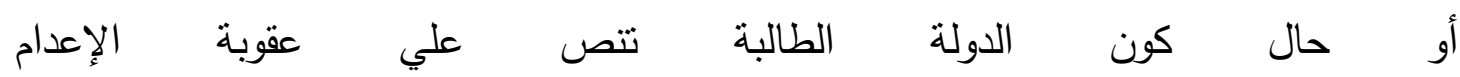

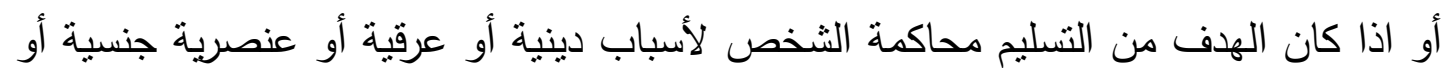

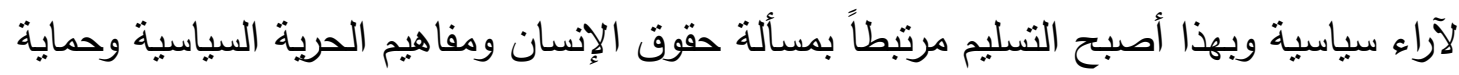
الأقليات وكلها تشكل منظومة قيم عالمية بدأت تترك آثارها على القوالب القانونية وأن هذا الطابع العالمي قد تولد عن انتشار الإتفاقيات الثنائية الإقليمية والعالمية في مجال التسليم.(() 


\section{المطلب الثالث}

\section{شروط التسليم}

لكي يتم تسليم المجرمين لا بد من توافر جملة من الثروط بعضها يتعلق بالثخص المطلوب تسليمه والبعض الآخر يتعلق بالجريمة سبب التسليم وسنتتاول هذه الثروط علي النحو التالي:

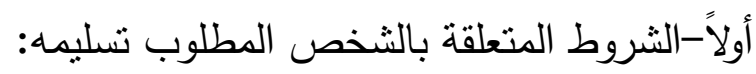
يعتبر الثخص المطلوب تسليمه محور إجراء التسليم لكن لعدة اعتبارات ليس كل متهم

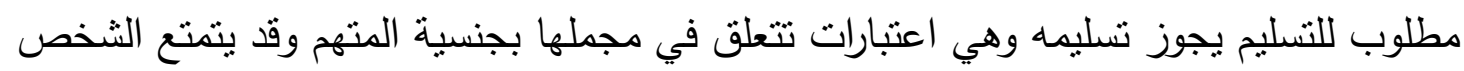

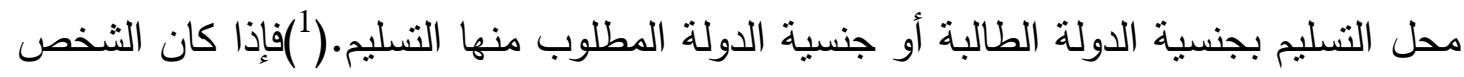

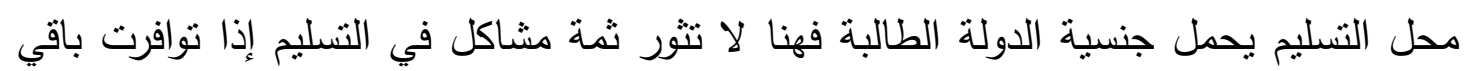

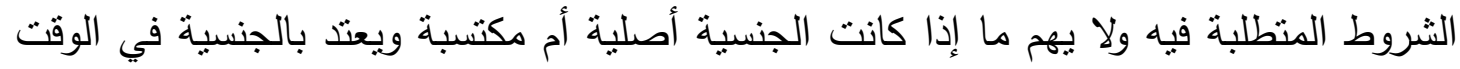
الذي ارتكبت فيه الجريمة وهو ما قضت به المادة(4/1-696)من قانون الإجراء ات الجنائية الفرنسي والمادة(6/30)من الاتفاقية العربية لمكافحة الجريمة المنظمة عبر الحدود الوطنية. ولكن تتور المشكلة اذا كان الثخص المطلوب نسليمه يحمل جنسية الدولة المطوب منها النسليم

حيث تختلف مواقف الدول من حيث سماحها بتسليم مواطنيها للدول الأخرى من عدمه.(")

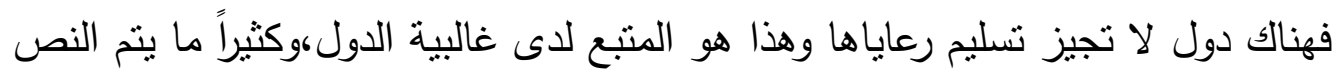

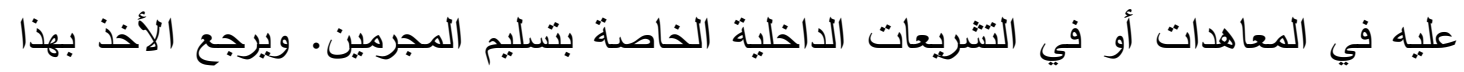

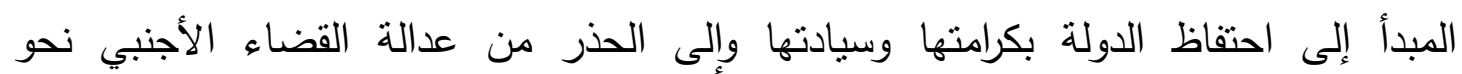

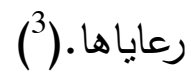
حيث يلاحظ أن الدول التي تأخذ بالتتريع اللاتيني(فرنسا ومن سار على نهجها) تأخذ بمبدأ

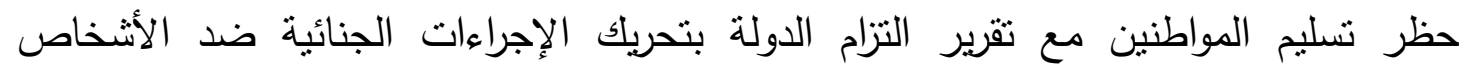

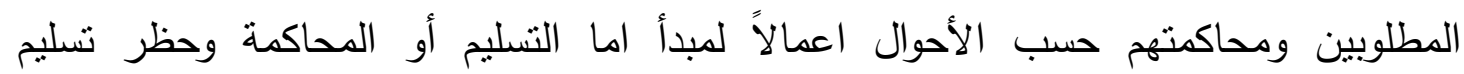

1-الجنسية هي صفة في الثخص تفيد انتسابه إلى دولة معينة وعضويته في شعبها وينم اضفاء ثلاك الصفة على الثخص أو خلعها عنه بمقتضي نظام قانوني محدد. راجع في ذلك:د.أحمد عبد الكريم سلامة،القانون الدولي الخاص،الجنسية والمعاملة الدولية للأجانب،القاهرة ،دار النهضة العربية،سنة .7. 2001 2- ذنايب آسية، الآليات الدولية لمكافحة جريمة المنظمة عبر الوطنية،مرجع سابق ،ص186.

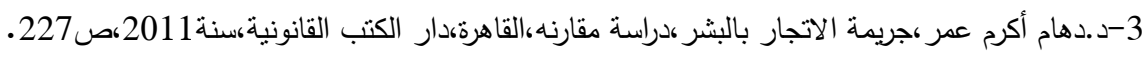


المواطنين قد يكون حظراً دستورياً وقد يرد في القوانين المنظمة لأحكام التعاون القضائي (الدولي. ( )

فعلي سبيل المثال تقضي اتفاقية المساعدة المتبادلة والتعاون القانوني والقضائي الموقعة

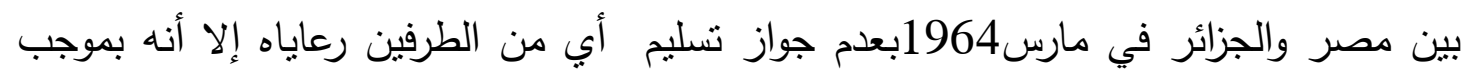

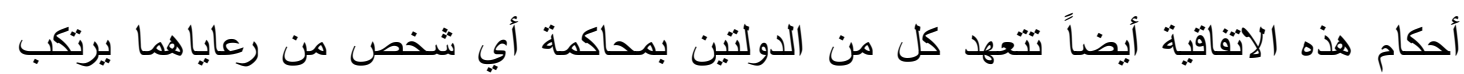

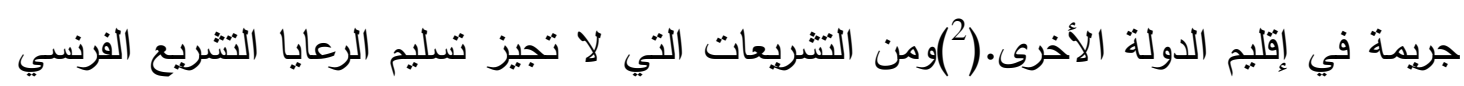

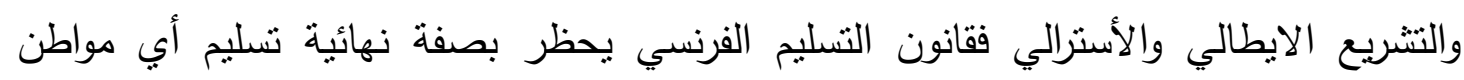

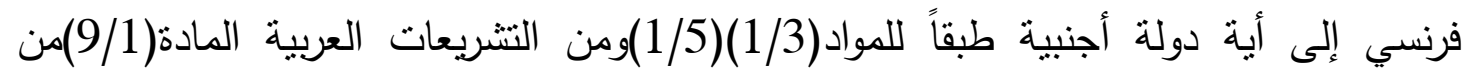

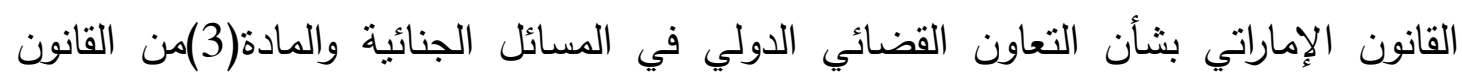

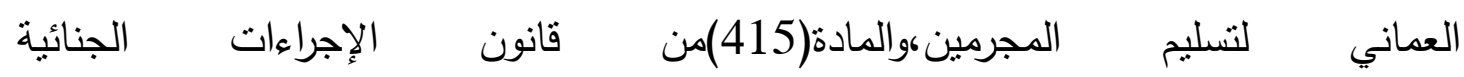

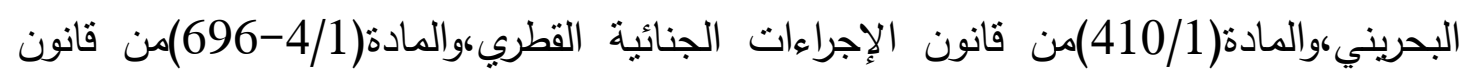

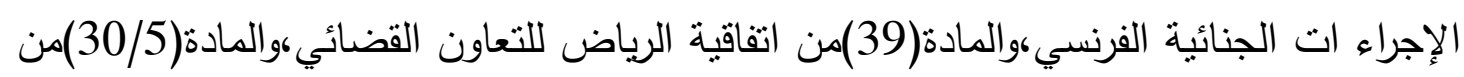
الاتفاقية العربية لمكافحة الجريمة المنظمة عبر الحدود الوطنية.

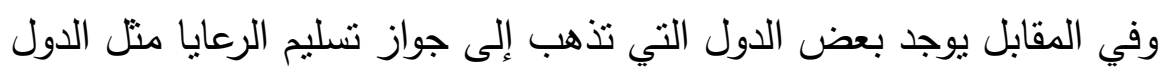

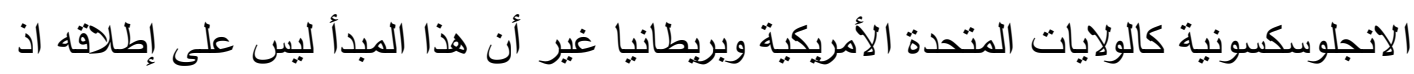

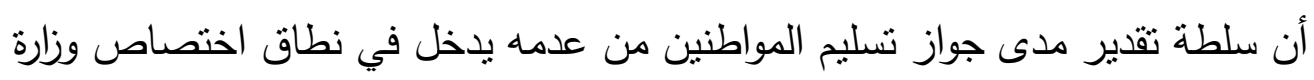

1-د.سليمان عبد المنع، الجوانب الاثكالية في النظام القانوني لتسليم المجرمين،مرجع سابق،ص223.

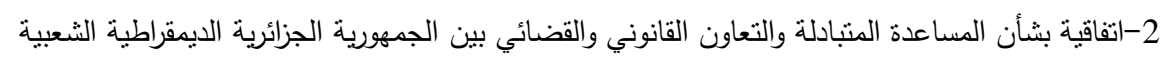

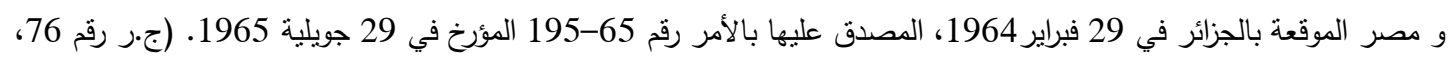

سنة 1966). تقضي المادة(24/1)من الاتفاقية المصرية الجزائرية بأنه لا يسلم أي من الطرفين المتعاقدين رعاياه وتحدد الجنسية في تاريخ وقوع الجريمة المطلوب من أجلها التسليم. 
الخارجية.(1) فمثلاً في أمريكا يكون لوزير الخارجية الأمريكي سلطة نقدير مدى جواز تسليم

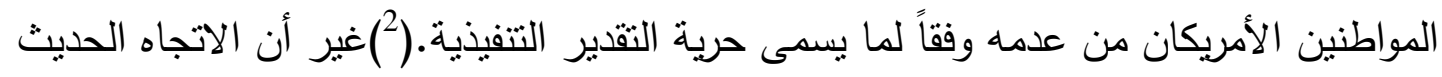

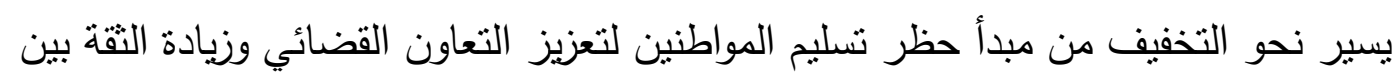

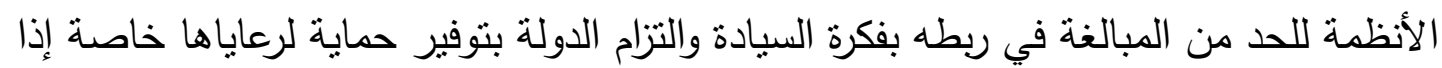

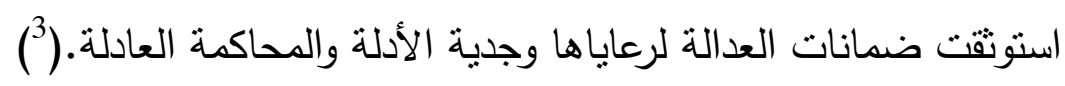
ثنانياً-الثروط المتعلقة بالجريمة سبب النسليم: تعد الجريمة هي محور تسليم المجرمين فبدون جريمة لا يوجد محل للتسليم ولكن لا بد بل

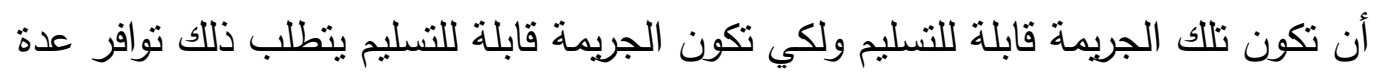

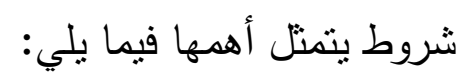
أ-ازدواجية التجريم(ازدواج التجريم):

يقصد بازدواج التجريم أن يكون الفعل سبب التسليم مجرما في قانون كل من الدولتين

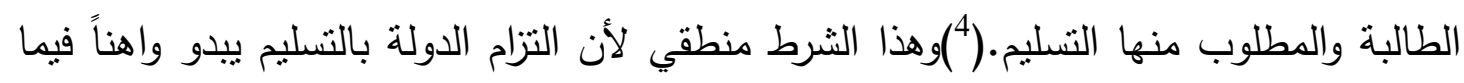

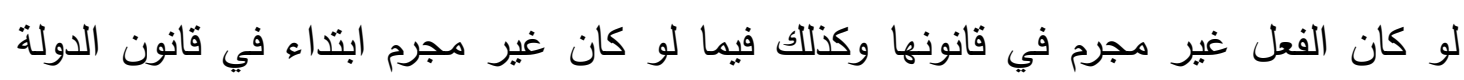

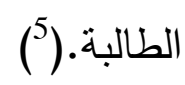
وفي الحالتين فإن الأمر ينطوي على المساس بحقوق تسليمه كون أن التسليم هو إجراء

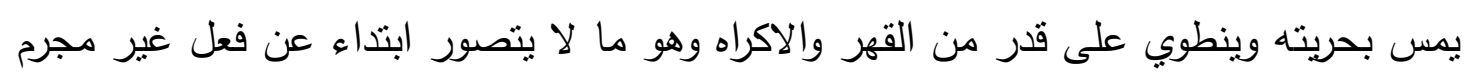

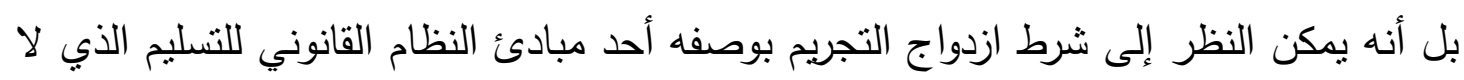

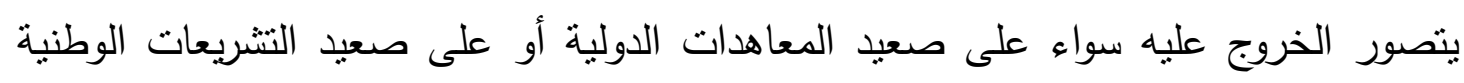

1-د.السيد رمضان عطية خليفة،تسليم المجرمين في إطار قواعد القانون الدولي،دراسة تأصبلية وتطبيقية،القاهرةدار النهضة

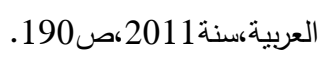

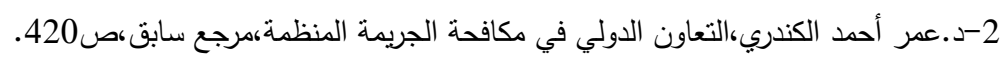

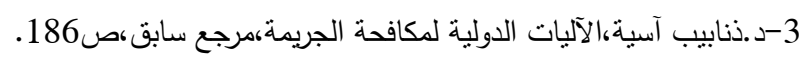

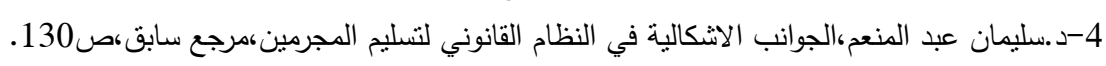

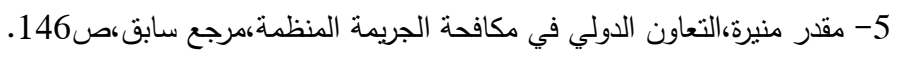


فضلاً عن أن الدولة المطلوب منها التسليم لن تكون لها أية مصلحة مؤكدة أو واضحة في إجابة طلب التسليم إذا كانت الجريمة موضوع التسليم غير معاقب عليها وفقاً لقانونها الداخلي.(1) ولقد أكدت على هذا الثرط المادة(16/1)من اتفاقية الأمم المتحدة لمكافحة الجريمة المنظمة عبر الوطنية والتي نصت على أن يكون المجرم الذي يلتمس بِّأنه التسليم معاقبا عليه بمقتضي القانون الداخلي لكل من الدولة الطرف الطالبة والدولة الطرف ملتقية

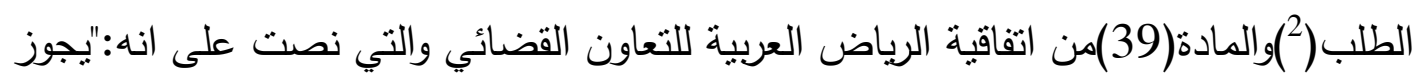

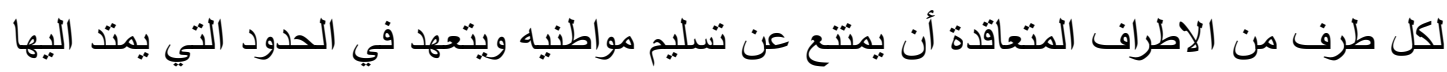
اختصاصده ، بتوجيه الاتهام ضد من برتكب منهم لدى أبي من الاطراف المنعاقدة الاخرى جرائم

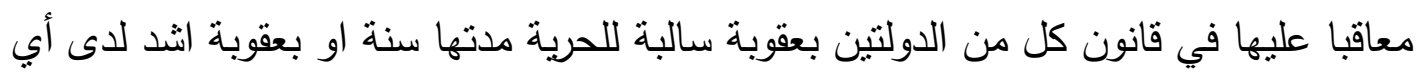
من الطرفين المتعاقدين وذلك اذا ما وجه اليه الطرف المتعاقد الاخر طلبا بالملاحقة مصحوبا لعابه بالملفات والوثائق والاشياء والمعلومات التي تكن في حيازته ويحاط الطرف المتعاقد الطالب علما بما تم في شأن طلبه 0 وتحدد الجنسية في تاريخ وقوع الجريمة المطلوب من اجلها التسليم".

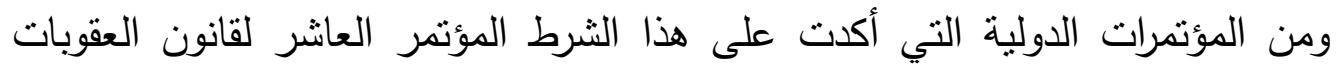
،ومن التشريعات الوطنية التي نصت على هذا الثرط المادة(13)من قانون العقوبات الإيطالي

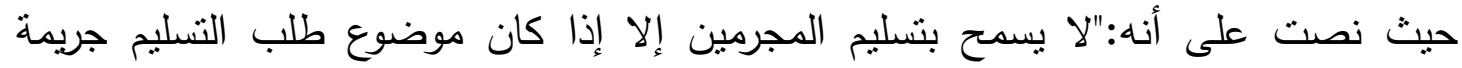
بموجب القانون الايطالي والقانون الأجنبي.

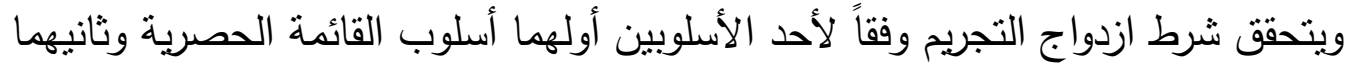

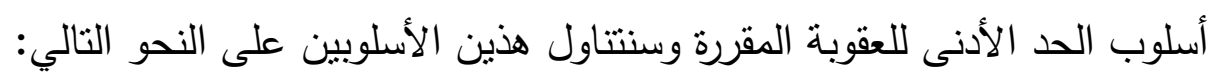

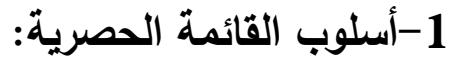

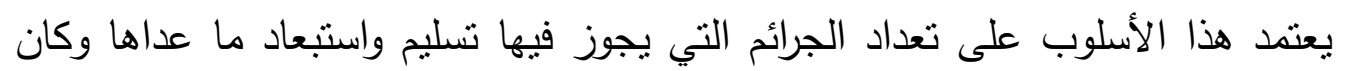
هذا الأسلوب هو الأكثر شيوعاً قبل الحرب العالمية الثانية واتبعته دول النظام الانجلوسكسوني التاني

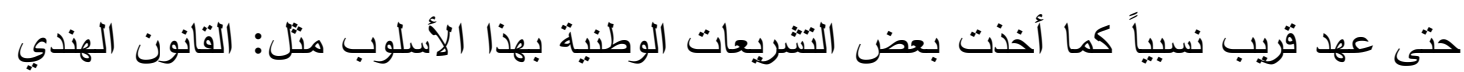
2-تتص المادة (16/1) من اتفاقية الأمم المتحدة لمكافحة الجريمة المنظمة عبر الوطنية على أنه:" تنطبق هذه المادة على الجرائم المشمولة بهذه الاتفاقية، أو في الحالات التي تتطوي على ضلوع جماعة إجرامية منظمة في ارتكاب جرم مشار إليه في الفقرة 1 (أ) أو لون

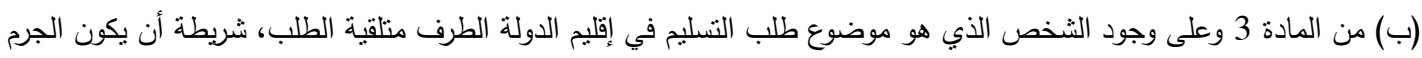
الذي يُلتمس بشأنه التنليم معاقبا عليه بمقتضى القانون الداخلي لكل من الدولة الطرف الطالبة والدولة الطرف متلقية الطلب. 
الذي كان يقصر نطاق التسليم على جرائم التهريب والاتجار في المخدرات والاتجار غير

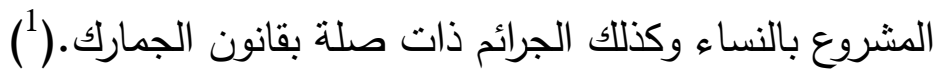
وينسم أسلوب القائمة الحصرية بالبساطة والفعالية ولا يثير صعوبات دات كتانلك التي تتشأ عن اختلاف التكييف الجرمي في تثريع الدولتين الطالبة والمطلوب إليها حالة الأخذ بأسلوب الحد

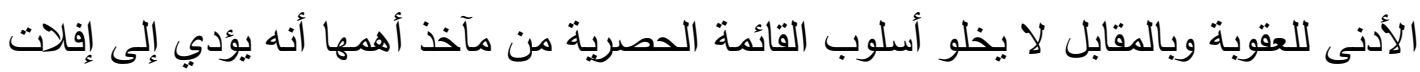

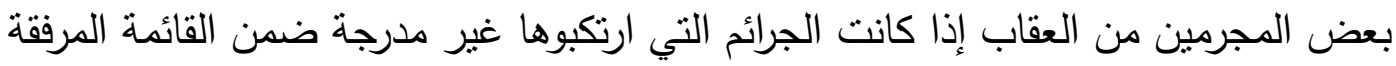

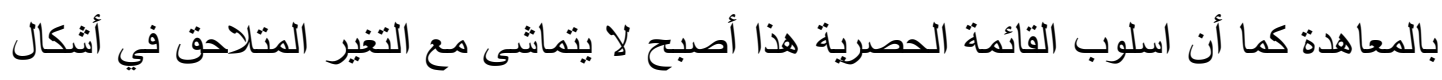

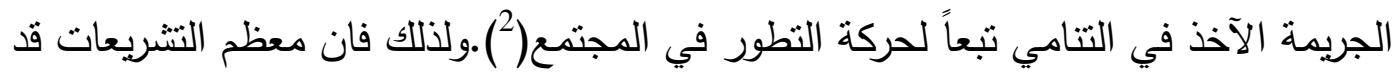

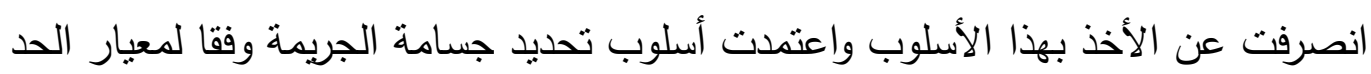
الأدنى للعقوبة.

\section{2-أسلوب العد الأدنى للعقوية المقررة:}

يعتمد أسلوب الدد الأدنى للعقوبة على جواز التسليم بشأن الجرائم التي تتجاوز عقوبتها

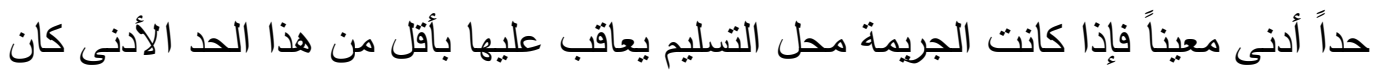

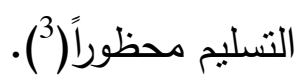
وينطوي أسلوب الحد الأدنى للعقوبة على مزايا عديدة أهمها، تفادي ما قد يكون هناك من

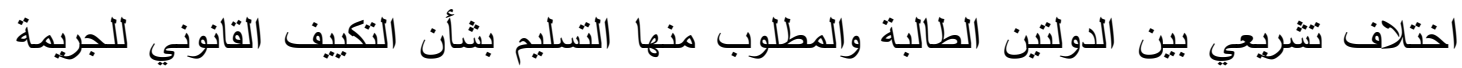

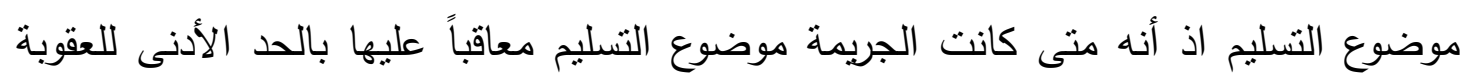

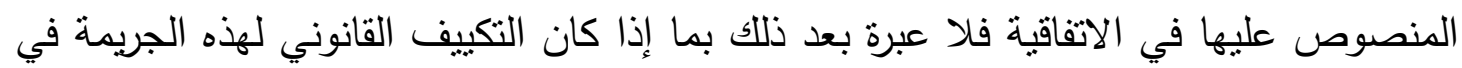

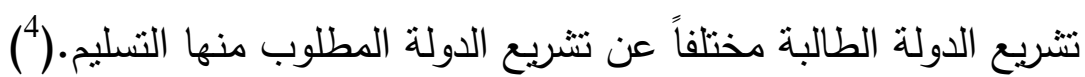

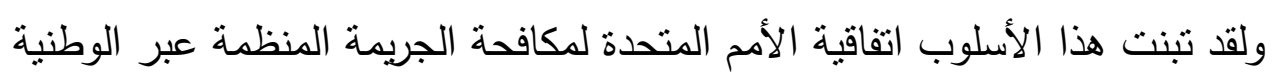

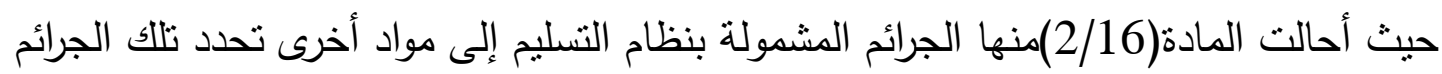

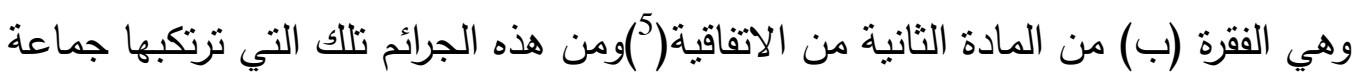

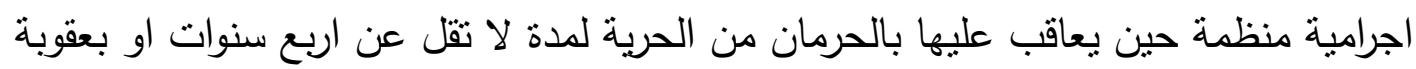


ولقد أكدت علي ذلك المادة(3)من اتفاقية نسليم المجرمين المعقودة بين دول الجامعة العربية حيث قضت بأنه يشترط النسليم أن تكون الجريمة جناية أو جنحة معاقبا عليها لمدة سنة

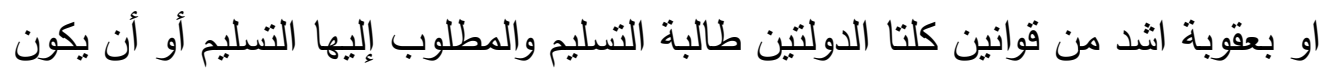
المطلوب تسليمه عن مثل هذه الجريمة محكوماً عليه بالحبس لمدة شهرين على الأقل. 3-الأسلوب المختلط: 3 - 3

يعد هذا الأسلوب من الأساليب الثائعة لتحديد الجرائم التي يجوز فيها التسليم إذ أنه يحقق فائدنين للدول الأطراف في المعاهدات فهو من جانب يضمن درجة معينة من جسامة الاسبة الجريمة المعاقب عليها بين البلدين ليتم التسليم وفقاً لها، كما يضمن جرائم محددة تنتل خطراً على الدول الأطراف تخضع أيضاً للنسليم، دون النظر لدرجة جسامتها أو العقوبة المقررة عليها. () ب-أن تكون الجريمة جنائية:

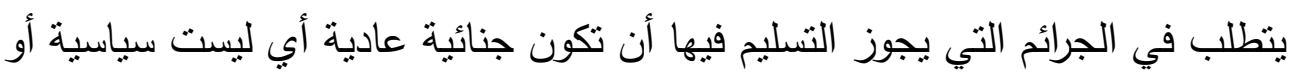

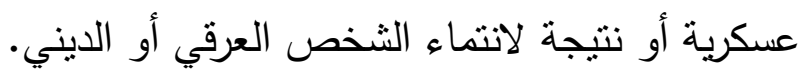

1-الجريمة السياسية:

والجريمة السياسية هي: "الجريمة التي يقع عدوانها على نظام الدولة السياسي مثل نظام

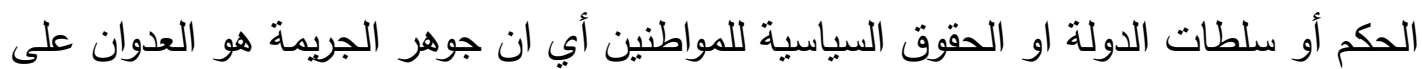

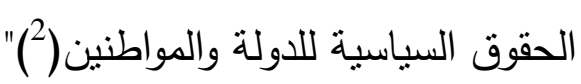

فمن المسلم به في العلاقات الدولية بين الدول أنه لا يجوز تسليم المجرمين السياسيين والعلة في ذللك ترجع إلى بعض الاعتبارات التي تحمل على معاملة المجرم السياسي معاملة خاصة فضلا عن ان النسليم يعطي الدولة المطلوب اليها التسليم فرصة للتنخل في الثئئن السياسية للاولة الطالبة(3).

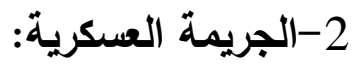

الجريمة العكرية هي: "الجريمة التي تقع من شخص ذي صفة عسكرية بالمخالفة

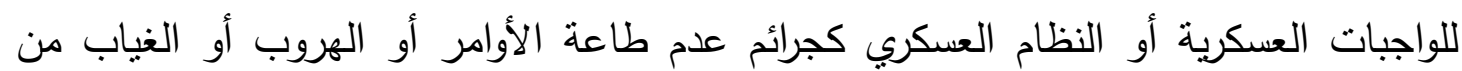

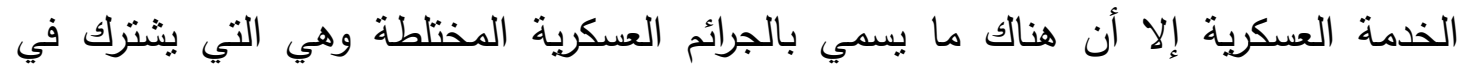
تجريمها قانون الأحكام العسكرية وقانون العقوبات معا كتسهيل دخول العدو أو جرائم الاختلاس

1-د.عبد الفتاح محمد سراج،النظرية العامة لتسليم المجرمين،مرجع سابق،ص263. 263.

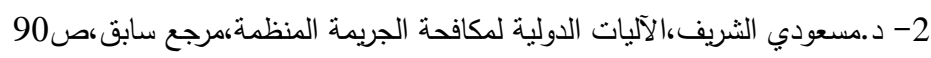

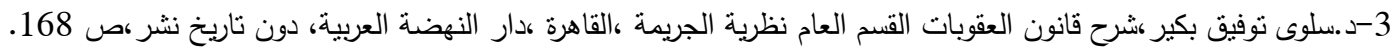


والسرقة وأهم ما يمبزها عن الجرائم العادية هو انعقاد الاختصاص بنظرها لقضاء استثنائي هو القضاء العسكري( أن.

وتتضح العلة من وراء عدم التسليم في الجرائم العسكرية إلى أن تلك الجرائم لا تتم عن نزعة إجرامية لدي مرتكبها ومبدأ عدم التسليم هنا مقصور علي الجرائم العسكرية البحتة ولا يمند

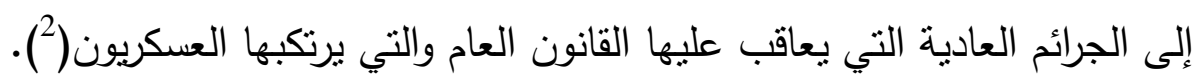
ج-عدم سقوط الجريمة أو العقوية بالنظام: من غير الجائز تسليم المجرمين إذا سقطت الجريمة أو العقوبة بالتقادم(3) تبعاً لقانون

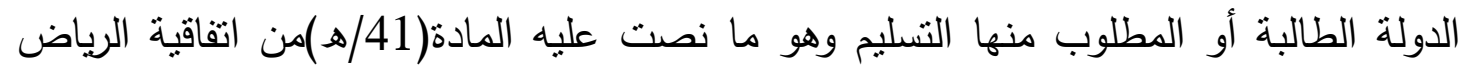

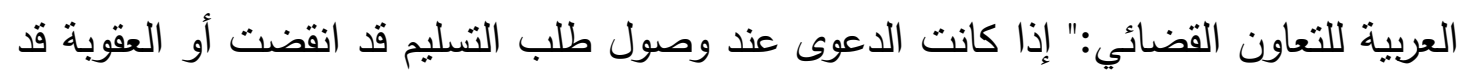

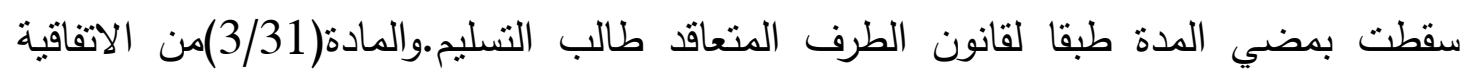

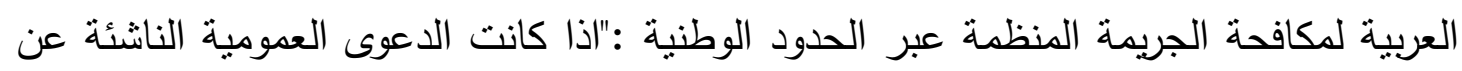

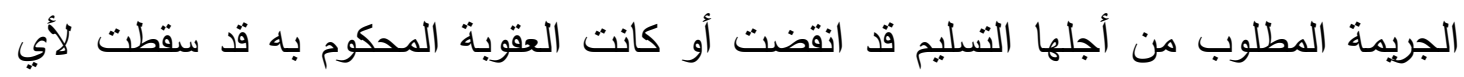
سبب من أسباب السقوط أو الانقضاء وفقاً لقانون الدولة طالبة النسليم.

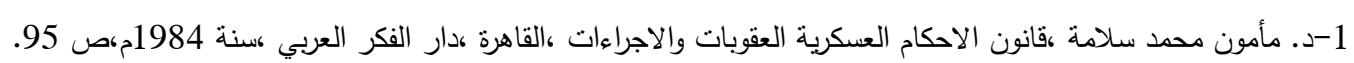

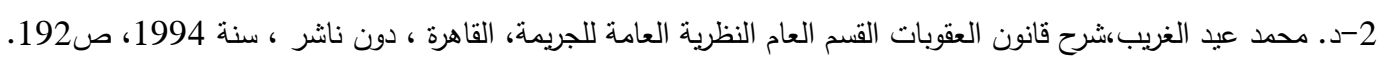

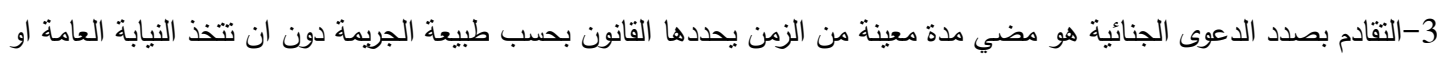

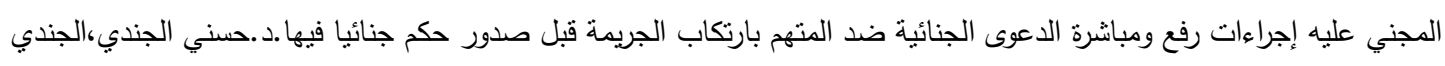

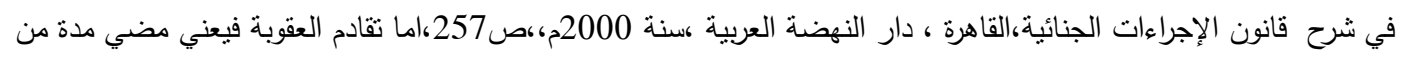

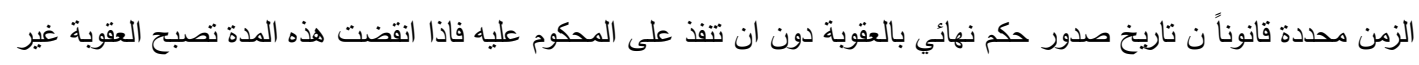

واجبة التنفيذ. راجع في ذلك:د.سلوى نوفيق بكير، ،العقبة في القانون الجنائي المصري،القاهرة ،دار النهضة العربية ،سنة 2001، ،ص212. 


\section{المبحث الثالث}

\section{تنفيذ الأحكام الجنائية الأجنبية}

تمهِبر وتقسيبح:

إذا كانت الأحكام الجنائية الصادرة بالإدانة هي إعلان حاسم بضرورة القصاص من المحكوم عليه وصولاً إلى اقتضاء حق المجتمع في العقاب وتحقيق اعتبارات العدالة، فإن مجرد صدور هذه الأحكام لا بعني تحقق هذه الغاية،إذ يقتضي ذلك تتفيذ هذه الأحكام بالفعل حيث تتحقق حينئز اعتبارات الردعهويتم إثباع متطلبات العدالة، وتهدأ نفوس من نالتهم الجريمة (1). بالإعتذاء. (1)

غير إنه قد يحدث في حالات غير قليلة،إن يرتكب الثخص الجريمة في إقليم دولة معينة ثم

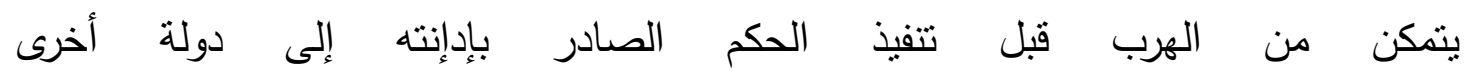
وتمتتع هذه الأخيرة بدورها عن تسليمه إلى دولة الإدإنة استتاداً إلى عدم توافر بعض شروط إنى إنه

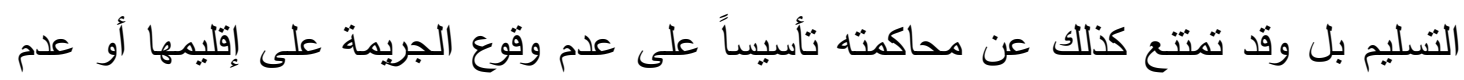
مساسها بمصالحها الأساسية أو عدم خضوعها للتجريم وفقا لأحكام قانونها الوطني.(2) وفي هذه الحالات وغيرها من الحالات المماثلة لا يمكن تتفيذ الحكم الصادر بالإدانة في إقليم الدولة الأجنبية تأسيساً على ما ينطوي عليه ذلك من مساس بسيادة هذه الدولة بحيث تظل الجريمة،من الناحية الواقعية دون عقاب على نحو تتأذى منه العدالة،وتتهار المساواة بين محكوم عليه خضع لتنفيذ الحكم الصادر بإدإنته، ومحكوم عليه ساعدته الظروف على الهرب(3) وهو ما يؤدي في نهاية الأمر إلى إن تصبح بعض الدول ملجأ للمجرمين والخارجين عن القانون،ويفضي إلى إضعاف قدرة المجتمع الدولي على مكافحة الاجرام.

1-د.عمر سالم،التعاون الدولي في تتفيذ الأحكام الجنائية الأجنبية،مجلة الفكر الثرطي،القبادة العامة لثرطة الثارقةهمركز بحوث

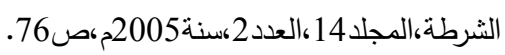
2-د.محمد فاضل،التعاون الدولي في مكافحة الإجرام،حلب، منشورات جامعة حلب،سنة2092 1992صاص262.

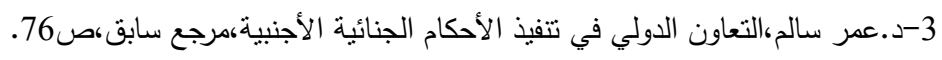


وانطلاقا من تلك الاعتبارات تبدو أهمية التعاون الدولي في تتفيذ الأحكام الجنائية الأجنبية بحسبإنه إحدى صور التعاون الدولي في مكافحة الاجرام.(1)

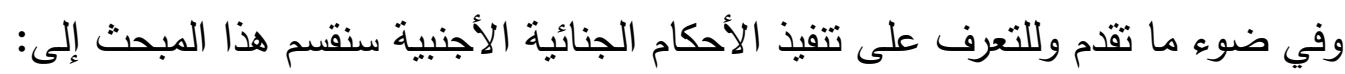
المطلب الأول: ماهية الحكم الجنائي الأجنبي. المطلب الثاني:الثروط العامة لتنفيذ الحكم الجنائي الأجنبي. المطلب الثالث:التعاون الدولي في تتفيذ الأحكام السالبة للحرية. 


\section{المطلب الأول \\ ماهية الحكم الجنائي الأجنبي}

إن إيضاح ماهية الحكم الجنائي الأجنبي يتطلب تعريف الحكم بصفة عامة ثم تعريف الحكم

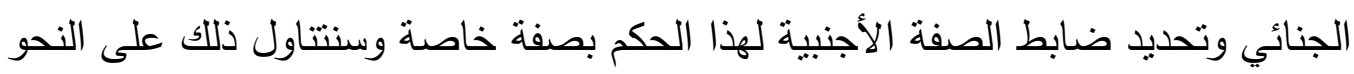
التالي: أولاًَ-تعريف الحكم القضائي:

تتعدد تعريفات الفقهاء للحكم القضائي وذلك نتيجة لاختلاف المعيار الذي يعتمد عليه كل اتجاه في تعريفه لهاففيؤخذ الحكم تارة بمعنى عضوي ليشمل كل ما يصدر عن القضاء من

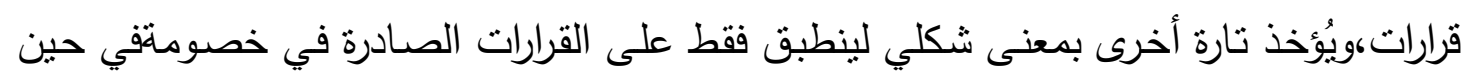

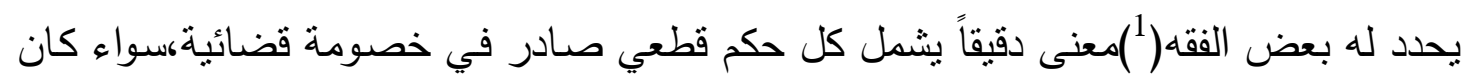

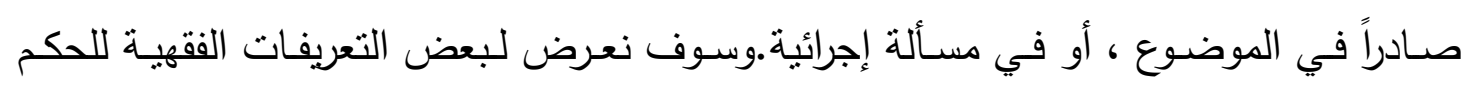
القضائي،وذلك على النحو التالي: التئي أ-الحكم بمعنـاه العـام: للقاضي وظيفتان:وظيفة ولائيـة أو إداريـة،وأخرى قضـائية يمارسهـا بمـا

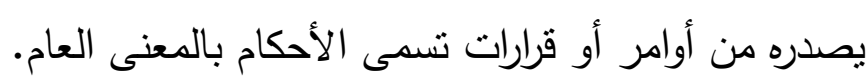

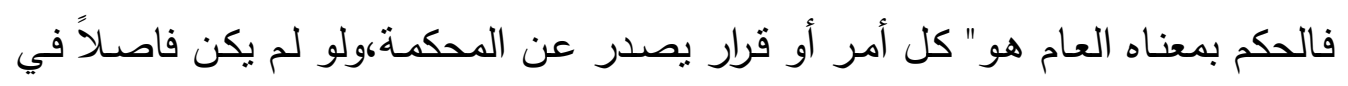

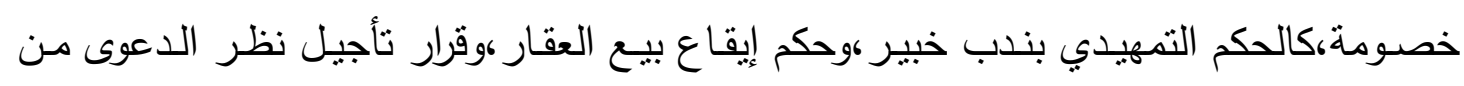

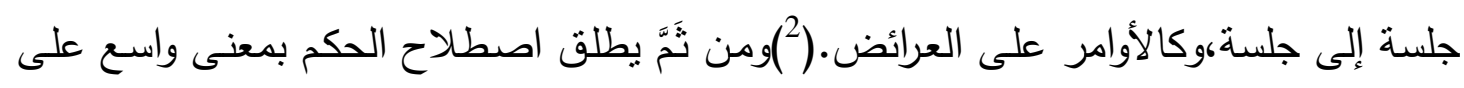

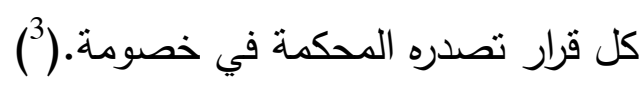

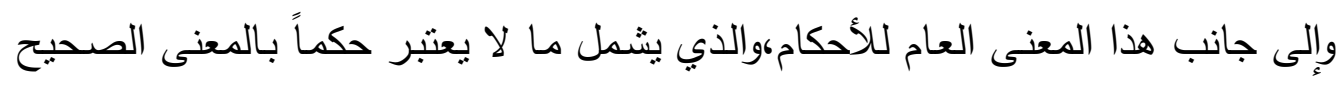

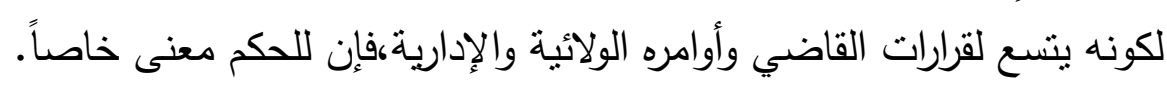

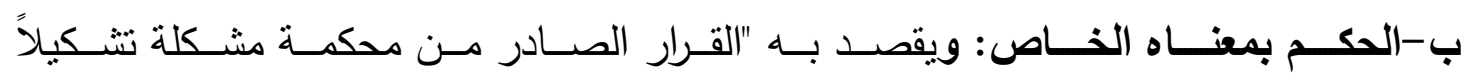

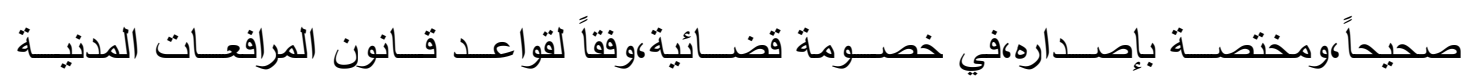

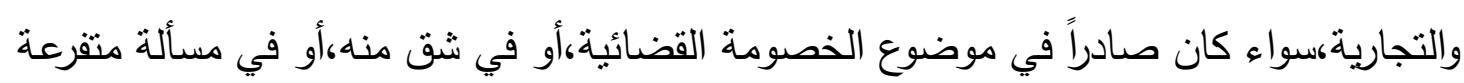

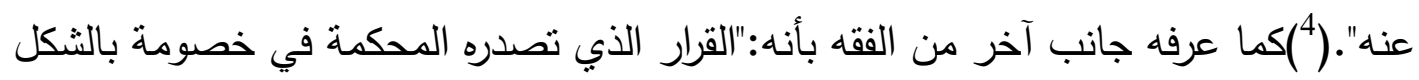

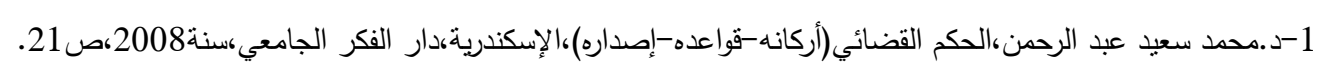

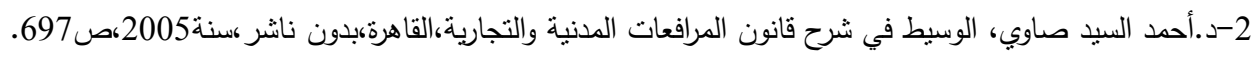

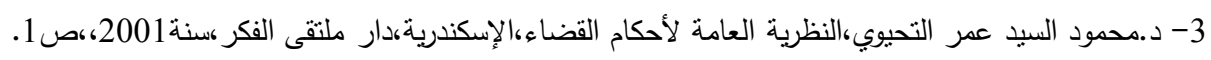

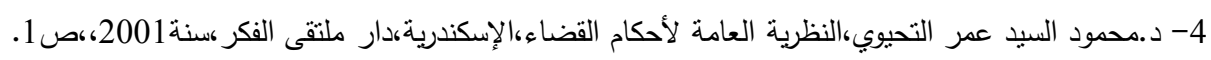


الذي يحدده القانون للأحكام،سواء في نهايتها، أو أثناء سيرها،وسواء كان صـادراً في موضوع

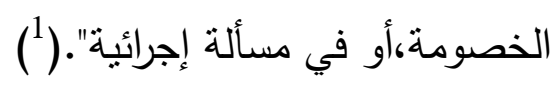

وعرفه جانب ثالث من الفقه بأنه:"القرار الصادر من شخص مزود بولاية القضاء،وبما له

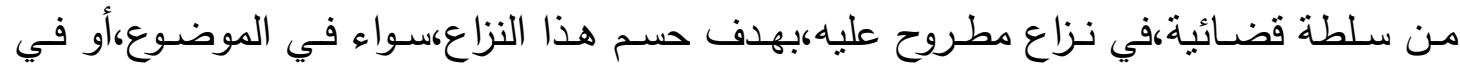

$$
\text { الإجراءات،ويصدر في الثكل المكتوب".((2) }
$$

يتضـح مما تقدم أن الحكم هو الثنكل الإجرائي العام الذي يصدر فيه القرار القضائي

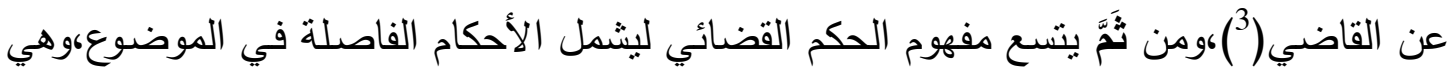
التي تفصل في الطلبات والدفوع الموضوعية،سواء بإجابتها أو رفضـها،والأحكام الإجرائية،وهي لإهي

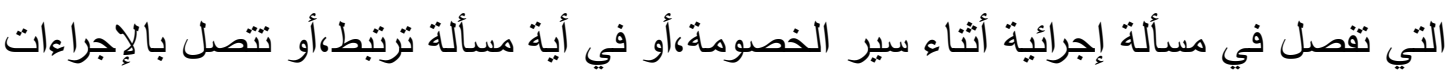

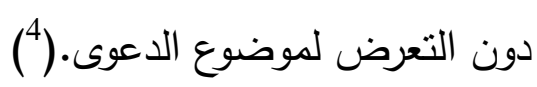

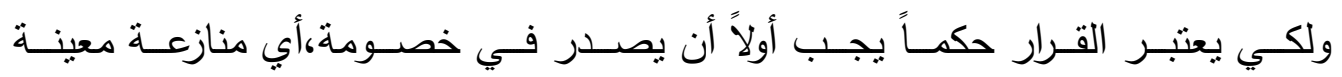
قامت،ونشأت بين شخصين أو أكثر ،وكذلك يجب ثانياً أن يصدر الحكم وفقاً لأشكال معينة وأن

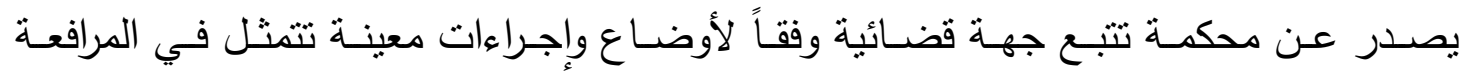

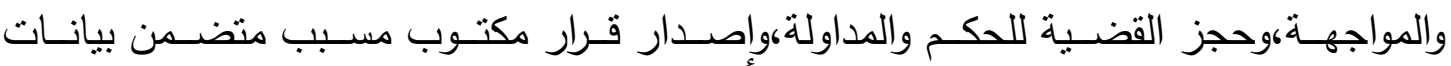

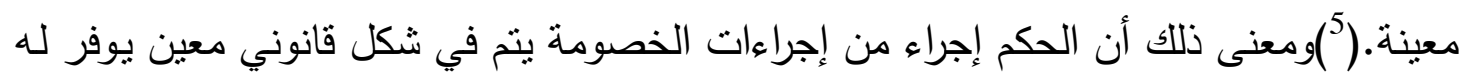

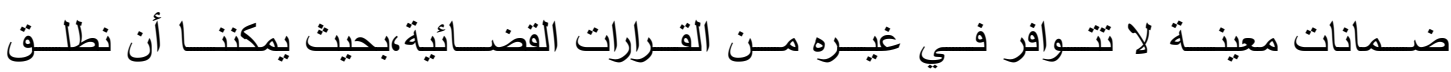
وصف"الحكم"على كل قرار يصدر من المحكمة في خصومة قضائية وفقاً لقواعد إصدار الأحكام

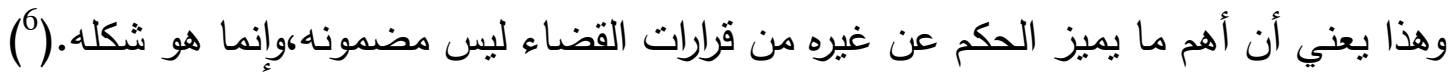

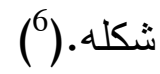

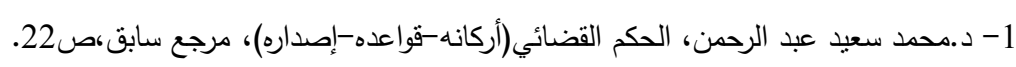

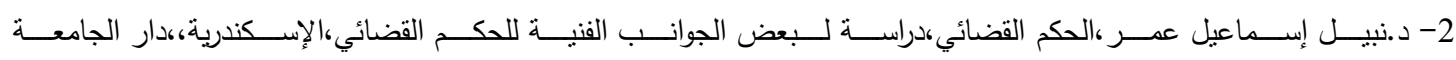

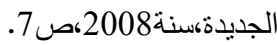

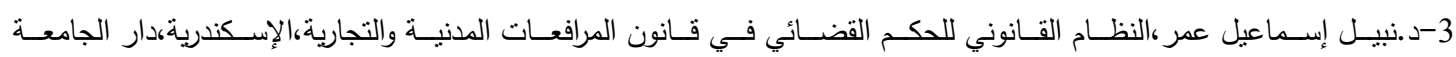

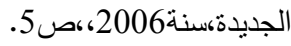
4- د.محمد سعيد عبد الرحمن، الحكم القضائي(أركانه-قواعده-إصداره) ،مرجع سابق،صاص222.

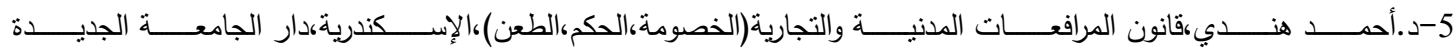

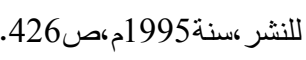
6- د.وجدي راغب ود.سيد أحمد محمود،قانون المرافعات الكويتي،الكويت،مؤسسة دار الكتب للطباعة،سنة1994،ص426. لمبن. 
ثانيا-تعريف الحكم الجنائي:

بالرغم من أن الحكم الجنائي لا يخرج في جوهره عن تعريف الحكم بصفة عامة إلا أن

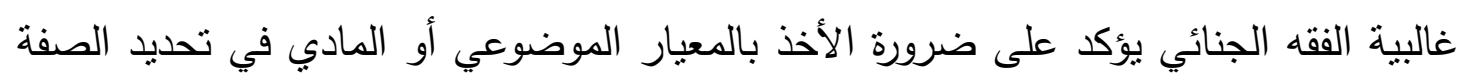

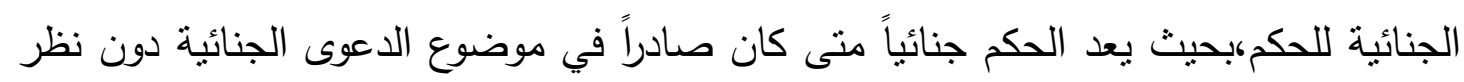

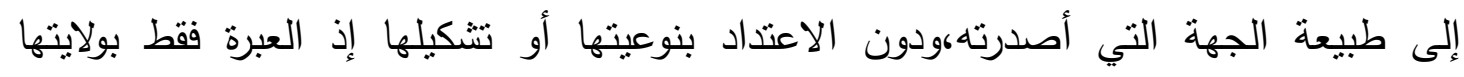
القضائية وبطبيعة الدعوى المنظورة أمامها وانطلاقا من ذلك يعرف الحكم الجنائي على أنه:

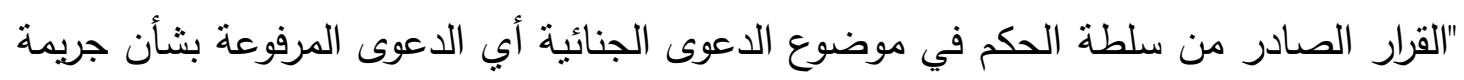

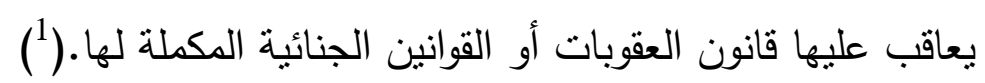

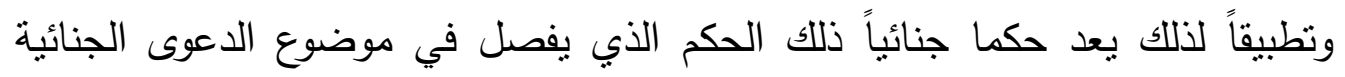

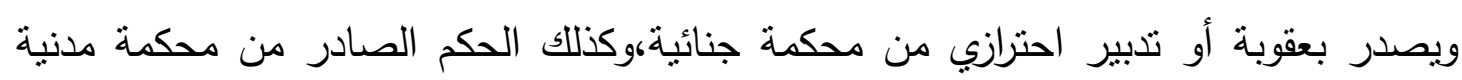

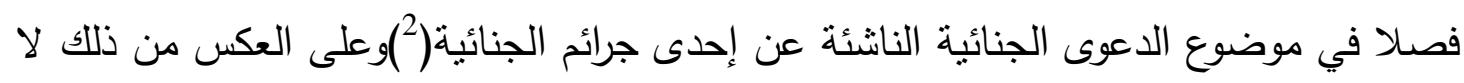

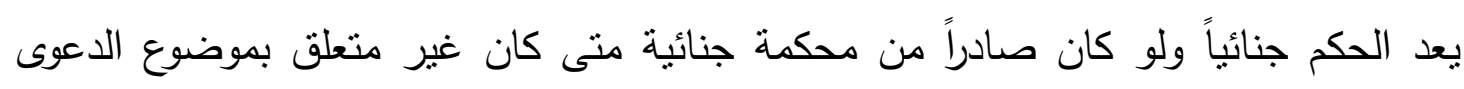

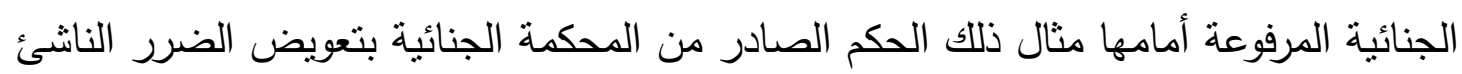
عن الجريمة إذ أن لهذا الحكم طابعا مدنبا حيث يهدف إلى تحقيق مصلحة فردية رغم صدوره

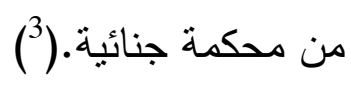

ثالثاً -تعريف الحكم الجنائي الأجنبي: يعرف الحكم الجنائي الأجنبي على أنه: "القرار الصادر في موضوع الدعوى الجنائية من

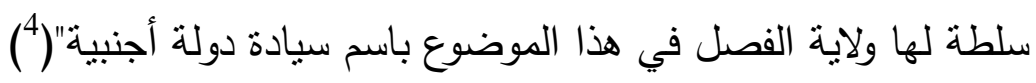

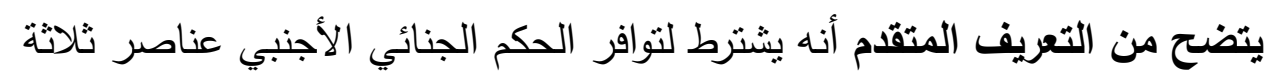

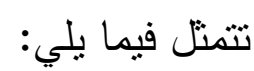
العنصر الأول: هو صدوره من سلطة الحكم في الدعوى،أي من هيئة لها ولاية إصدار الحكم الأجنبي وفقا للمبادئ أو القواعد التي تحدد اختصاص هذه الهيئة وتتظم عملها والمقررة

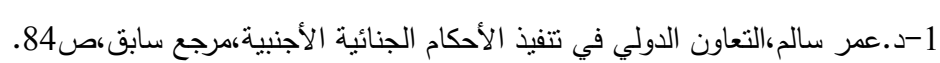

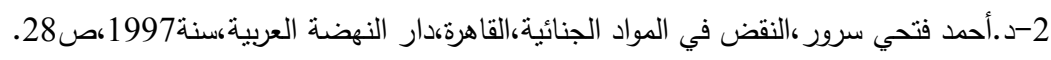

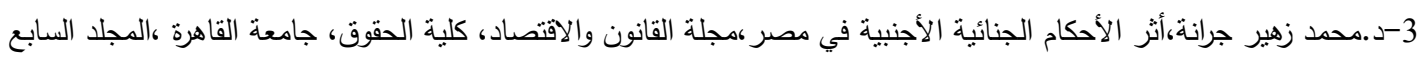

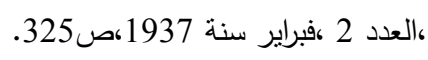
4-د.فتحي المصري بكر ،قوة الثئ المقضي به في المجال الجنائي،رسالة دكتوراهجامعة القاهرة،كلية الحقوق،سنة1989،ص125. 
في الدولة التي تتبعها هذه الهيئة يستوي بعد ذلك أن تكون الهيئة محكمة عادية أو استثائية،أو

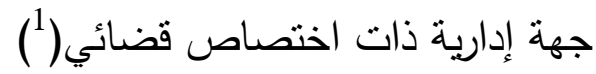
والعنصر الثاني: هو صدور هذا الحكم في موضوع الدعوى الجنائية،أي الدعوى

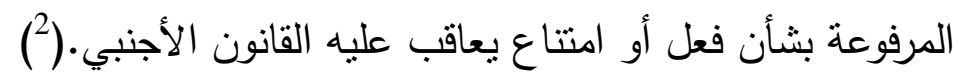

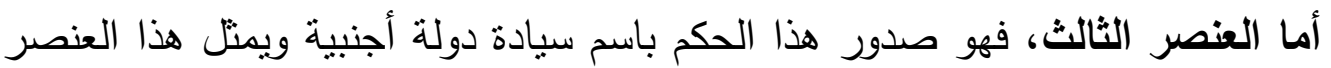

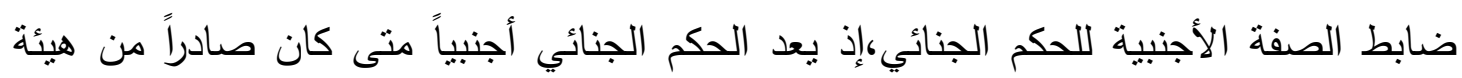

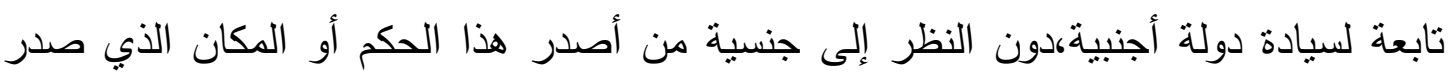
فيه.

وعلى ذللك يعد الحكم الصادر من المحاكم الخاصة برجال القوات الأجنبية المرابطين في إقليم

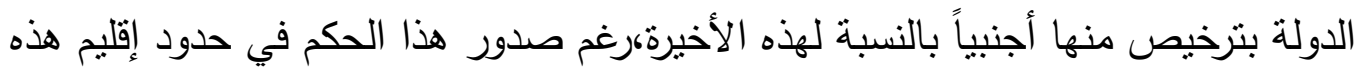

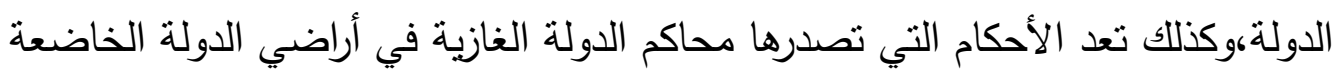
للاحتلال أحكاماً أجنبية بالنسبة لهذه الأخيرة رغم صدورها فوق أراضيها.وعلى العكس،يعد وطنياً

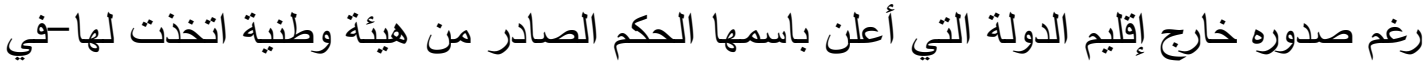

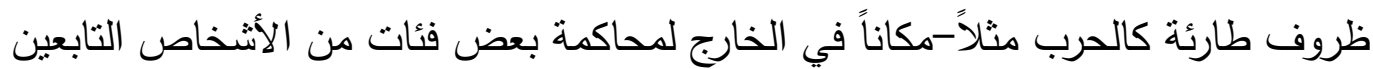

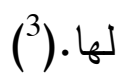

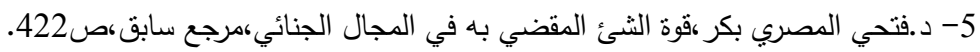

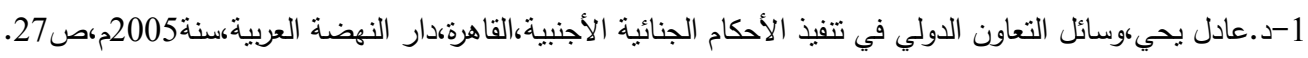

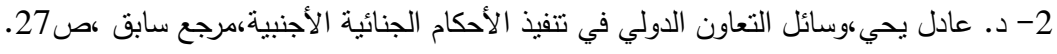




\section{المطلب الثاني \\ الثروط العامة لتنفيذ الحكم الجنائي الأجنبي}

يعد تتفيذ الحكم الجنائي الاجنبي في غير دولة الإدانة من أهم وسائل التعاون الدولي في تتفيذ

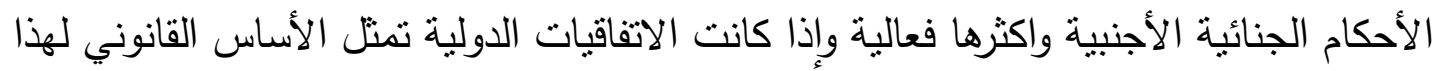

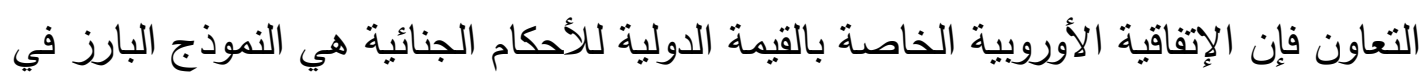
مجال تحديد شروط تنفيذ الحكم الجنائي الاجنبي. حيث تتاولت المواد من الأولى وحتي الرابعة من هذه الاتفاقية(1) تحديد الثروط التئي التئي

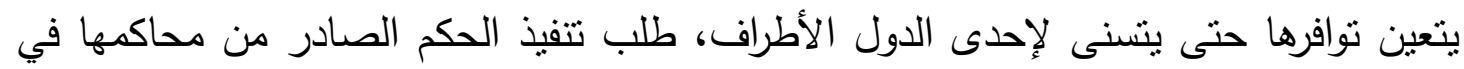
إقليم دولة أخرى طرف في هذه الاتفاقية.

وباستقراء نصوص هذه المواد نجدها تشبير إلى ضرورة أن ينعلق الأمر بحكم جنائي وأن

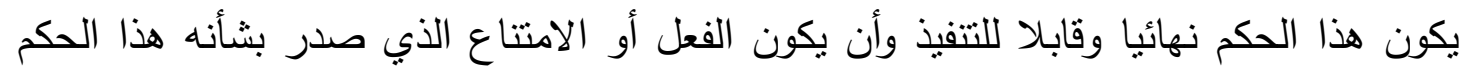

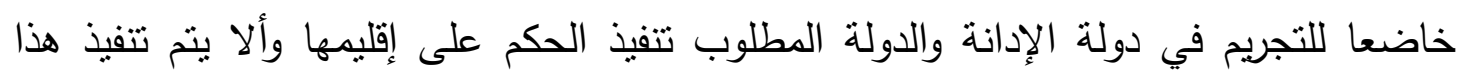

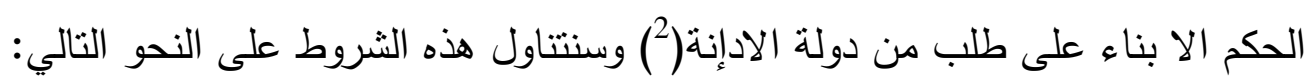

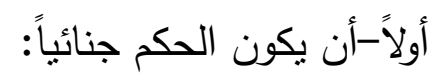

لقد أثنارت إلى هذا الثرط المادة الأولى من الإتفاقية الأوروبية الخاصة بالقيمة الدولية

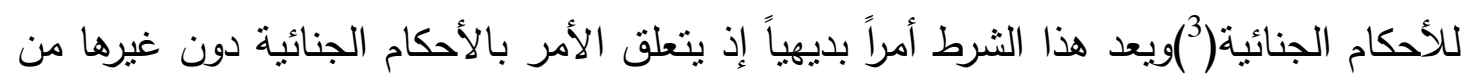

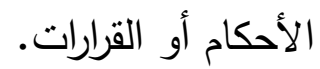

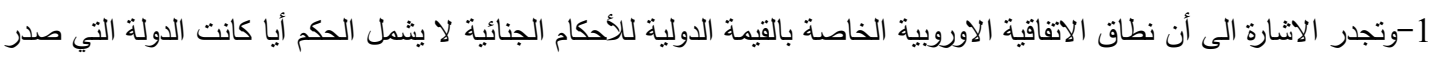

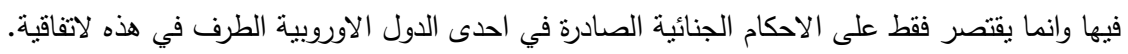

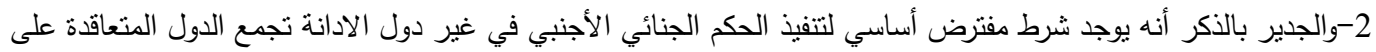

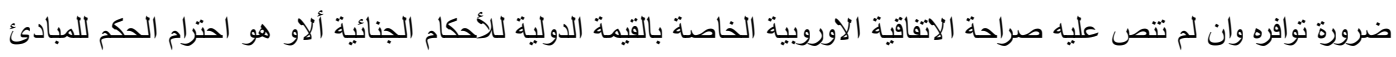

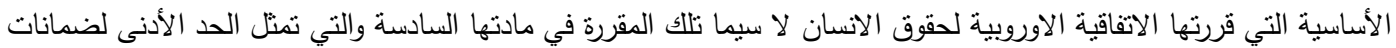

الملاحقة القضائية العادلة.

3- European Convention on the International Validity of Criminal Judgments

European Treaty Series - No. 70

"Offence" comprises, apart from acts dealt with under the criminal law, those dealt with=

$=$ under the legal provisions listed in Appendix II to the present Convention on condition that where these provisions give competence to an administrative authority there must be opportunity for the person concerned to have the case tried by a court 
والحكم يكون جنائياً بصدوره في دعوي جنائية سواء صدر عن القضاء الجنائي العادي أو

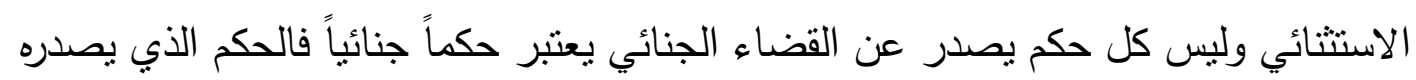
هذا القضاء في الدعوي المدنية لا يعتبر حكماً جنائياً.(1)

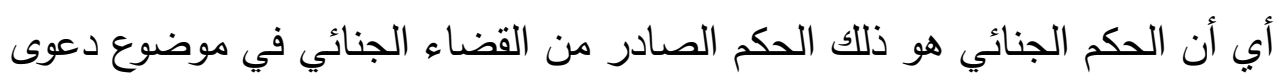
جنائية بشأن فعل يدخل في عداد الجرائم المعاقب عليها بعقوبة أو بندبير احترازي ومن ثم هن

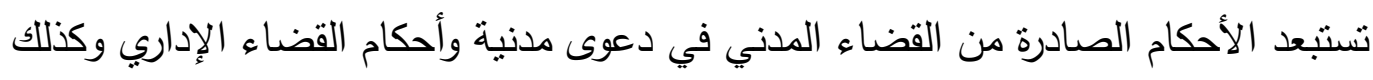
الأحكام التي يصدرها القضاء الجنائي ولكن في موضوع دعوى مدنية بالتعويض عن الاضرار الناشئة عن الجريمة.(2)

وتجدر الاشارة إلى أن التعريف السابق للحكم الجنائي وإن لم ينطبق على الأوامر

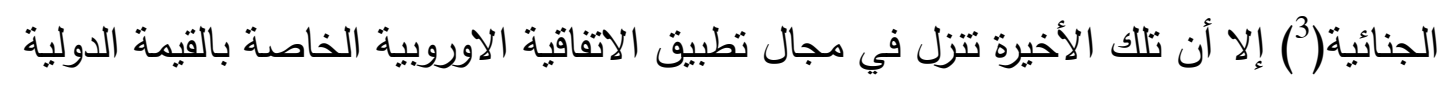
للأحكام الجنائية وإعمالا لنص المادة(21)منها منزلة الحكم الجنائي.

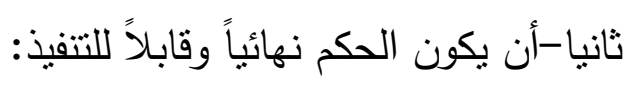
هذا الثرط نصت عليه الفقرة الأولى من المادة الأولي من الاتفاقية الأوروبية الخاصة

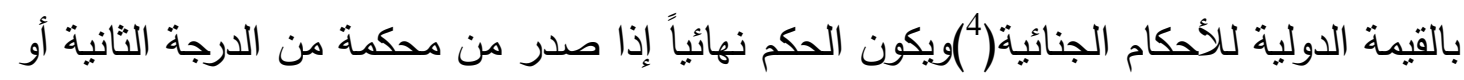

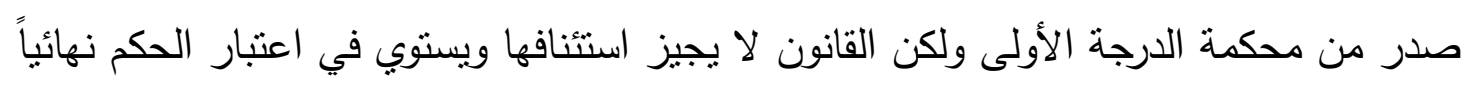
أن يكون قد صدر غير قابل للطعن بالإستئناف أو أن تترك مواعيده تتقضي أو أن بطعن فئ الأنيه

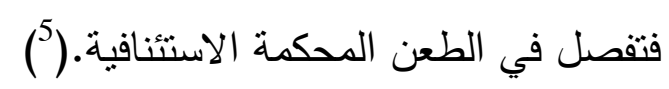

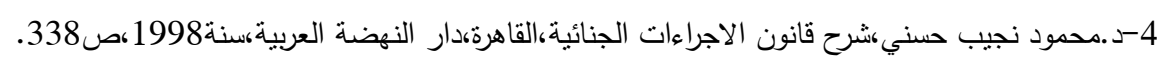

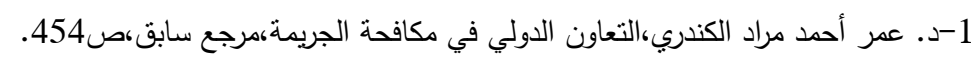

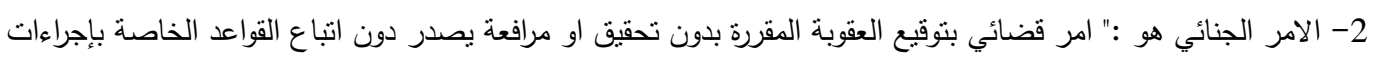

$$
\begin{aligned}
& \text { المحاكمة والتحقيق النهائي اللازم للحكم الجنائي. }
\end{aligned}
$$

3- "European criminal judgment" means any final decision delivered by a criminal court of a Contracting State as a result of criminal proceedings

$$
\text { 4- د. محمود نجيب حسني، شرح قانون الاجراءات الجنائية ،مرجع سابق،ص974. }
$$


أي إن الحكم النهائي هو الحكم الحائز لقوة الثئ المحكوم فيه والذي لا يقبل الطعن فيه بإحدى طرق الطعن العادية إما لصدور الحكم غير قابل للطعن فيه ابتداء وإما لاستنفاذ هذه الطرق أو لون تقويت المواعيد المقررة لها دون ممارستها. أما بالنسبة للأحكام الغيابية فقد تتاولتها المادة(21)من الاتفاقية ووضعت لها قواعد خاصة بها ( 1) وعلى الصعيد التشريعات الوطنية يشترط المشرع الفرنسي لتنفيذ الحكم الأجنبي الصادر بالمصادرة أن يكون الحكم نهائياً وأن يظل مكتسباً قوته التتفيذية وفقاً لقانون الدولة الطالبة.

أما على الصعيد الاتفاقيات الدولية الثنائية فتشتزط اتفاقية التعاون القضائي بين مصر والأردن اتفاقية رقم 3 لعام 2001م أن يكون الحكم الجنائي باتاً وواجب التتفيذ حتى يمكن الاستجابة لطلب نقل المحكوم عليهم بعقوبة سالبة للحرية لتنفيذها في الدولة التي ينتمون إليها فتتص المادة(57)منها على أن:" تنفذ الأحكام الجنائية الباتة وواجبة التتفيذ الصادرة لدى أحد البلدين المتعاقدين في إقليم البلد الآخر إذا كان المحكوم عليه متمتعا بجنسية ذلك البلد بناء على طلبه أو من يمثله إذا توافرت الثروط التالية..." الثرئ وعلي صعيد الاتفاقيات الاقليمية تنص المادة(58)من اتفاقية الرياض العربية للتعاون القضائي والتي وقعت عام 1983م ودخلت حيز النفاذ عام 1985م على أنه:"يجوز تتفيذ الأحكام الجزائية المكتسبة الدرجة القطعية (النهائية) والصادرة لدى أحد الأطراف المتعاقدة في إقليم أي من الأطراف الأخرى الذي يكون المحكوم عليه من مواطنيه، بناء على طلبه، إذا نوافرت الثرط

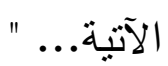

كما توجب الاتفاقية الأوروبية الخاصة بالقيمة الدولية للأحكام الأجنبية على الدولة التي

تطلب تتفيذ الحكم الجنائي الصادر من محاكمها في إقليم دولة متعاقدة أخرى أن تقدم ما يفيد قابلية ذلك الحكم للتفيذ وفقا للقواعد المقرة في تشريعها الداخلي(2) حتى يتسنى للدولة المطلوب منها تتفيذ هذا الحكم التحقق من ذلك.

\section{2- Article 21}

1- Unless otherwise provided in this Convention, enforcement of judgments rendered in absentia and of ordonnances pénales shall be subject to the same rules as enforcement of other judgments.

2- Except as provided in paragraph 3, a judgment in absentia for the purposes of this Convention means any judgment rendered by a court in a Contracting State after criminal proceedings at the hearing of which the sentenced person was not personally present. 3- Without prejudice to Articles 25, paragraph 2, 26, paragraph 2, and 29, the following shall be considered as judgments rendered after a hearing of the accused:

a any judgment in absentia and any ordonnance pénale which have been confirmed or pronounced in the sentencing State after opposition by the person sentenced; $\mathrm{b}$ any judgment rendered in absentia on appeal, provided that the appeal from the judgment of the court of first instance was lodged by the person sentenced.= 
ثالثاًَازدواج التجريم في دولة الإدانة ودولة التتفيذ:

لقد نصت على هذا الثرط المادة الرابعة من الاتفاقية الأوروبية الخاصة بالقيمة الدولية

للأحكام الجنائية(1)إذا اشترطت في فقرتها الأولي لتنفيذ الحكم الجنائي الصادر في إحدى الدول

الأطراف في إقليم دولة متعاقدة أخرى أن يكون الفعل أو الامتتاع الذي صدر بشأنه الحكم خاضعاً للتجريم وفقا لقانون كل من الدولتين ولا يقتضي استيفاء هذا الثرط وفقا لنص هذه الفقرة اعادة بحث مدى خضوع الفعل للتجريم أو العقاب وفقا لقانون دولة الإدانة اذ يعد الحكم الصادر بالإدانة دليلا على تحققه.(2)وإنما يقتضي فحسب التحقق من أن الفعل بعد في حالة ارتكابه في دولة التنفيذ جريمة وفقا لقانون هذه الأخيرة وإن مرتكب هذا الفعل معاقب على ارتكابه.(3) ويكون للاولة المطلوب منها تتفيذ الحكم الأجنبي الصادر من محاكم الدولة أخرى طرف في الاتفاقية سلطة بحث مدى توافر التجريم المزدوج للفعل في ضوء الأحكام القانونية لكل من البلدين ولها عند الثك أن تطلب مزيداً من الايضاح من الدولة التي صدر الحكم من محاكمها بشأن الوقائع التي أوردها الحكم(4) (

وفي حالة تعدد الأفعال الصادرة بشأن الحكم المطلوب تتفيذه فإنه يتم التيقن من توافر شروط التجريم المزدوج بشأن كل منها فإذا كانت هناك أفعال غير مستوفاة لشرط التجربم المزدوج فلا تثور صعوبة ما بشأنها إذا كان الحكم قد تضمن لكل فعل عقوبة مستقلة حيث يمكن الامتتاع عن تتفيذ العقوبات الصادرة عن أفعال مستوفاة لشرط التجريم المزدوج وتنفيذ تلك فئه الصادرة بشأن أفعال مجرمة في كل من البلدين.أما إذا كانت الأفعال بعضها مستوف لثرط لشان التجريم المزدوج والآخر غير مستوف لهذا الثرط وصدر بشأنها جميعا حكم واحد فإنه بجوز للاولة المطلوب منها نتفيذ الحكم على إقليمها إن تمتتع عن تتفيذ هذا الحكم كلية(5)

The request for enforcement shall be accompanied by the original, or a certified copy, of the decision whose enforcement is requested and all other necessary documents. The original, or a certified copy, of all or part of the criminal file shall be sent to the requested State, if it so requires. The competent authority of the requesting State shall certify the sanction enforceable.

2- Article 4

1- The sanction shall not be enforced by another Contracting State unless under its law the act for which the sanction was imposed would be an offence if committed on its territory and the person on whom the sanction was imposed liable to punishment if he had committed the act there.

2- If the sentence relates to two or more offences, not all of which fulfil the requirements of paragraph 1 , the sentencing State shall specify which part of the sanction applies to the offences that satisfy those requirements.

3-وتأكيدا على ذلك نصت الفقرة الثالنية من المادة العاشرة من الاتفاقية على أن الدولة التي تطلب تتفيذ الحكم-دولة الادانة-هي التي

تختص وحدها بالت في أب طعن في الحكم الصادر بالإدانة.

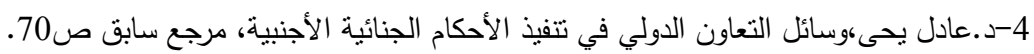

\section{2- Article 17}

If the requested State considers that the information supplied by the requesting State is not adequate to enable it to apply this Convention, it shall ask for the necessary additional information. It may prescribe a date for the receipt of such information

3- Article 6 
رابعاً-أن تطلب دولة الإدانة تتفيذ الحكم:

وهذا الشرط قد نصت عليه بصورة ضمنية الفقرة الثانية من المادة الثالثة من الاتفاقية

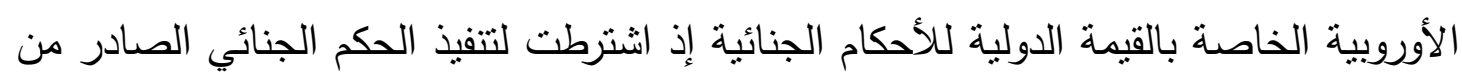

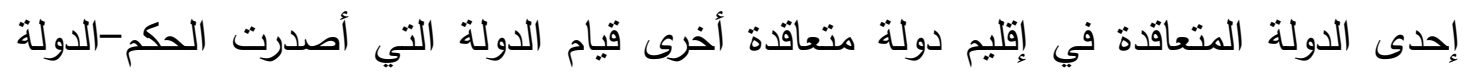

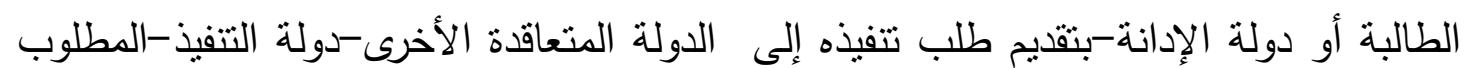
منها تتفيذ هذا الحكم على اقليمها (1). ويكتسب هذا الثرط أهيته البالغة بحسبانه السبب المنشئ للعلاقة القانونية الخاصة بين الدولة

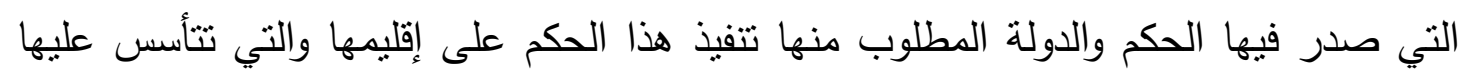

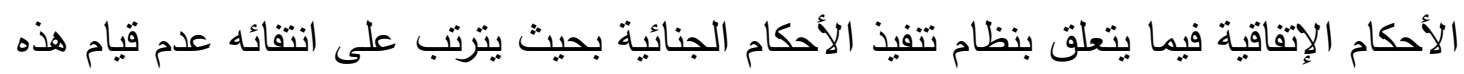

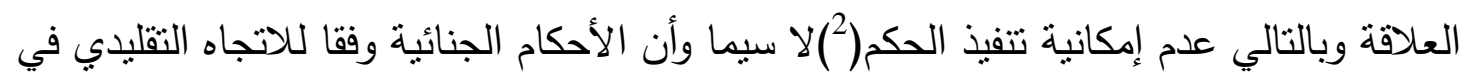

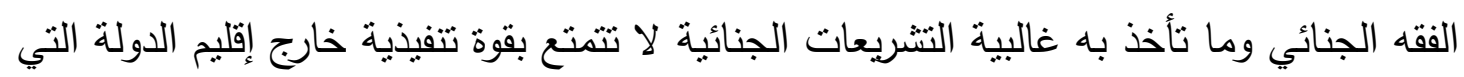

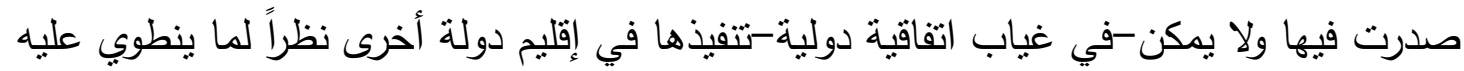

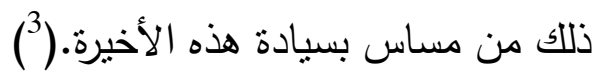

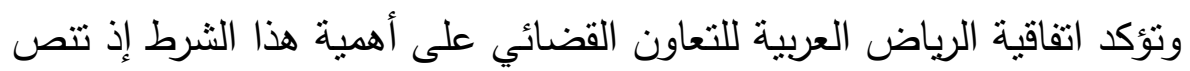

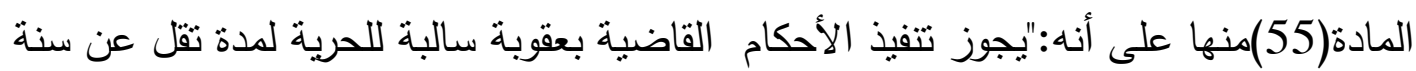

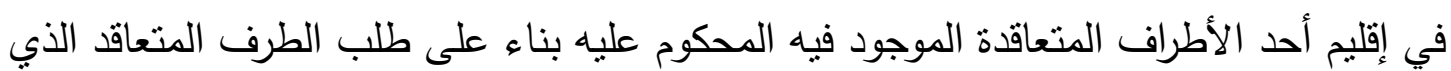
أصدر الحكم إذا وافق على ذلك المحكوم عليه والطرف المتعاقد المطلوب لديه التنفيذ".

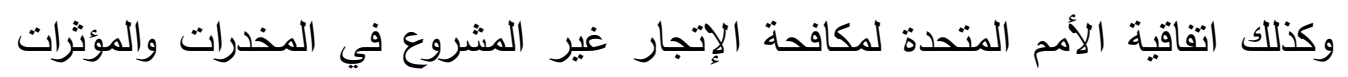

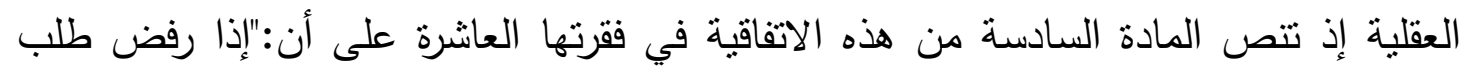

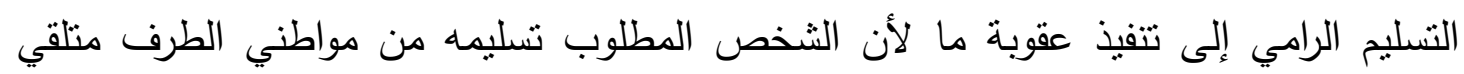

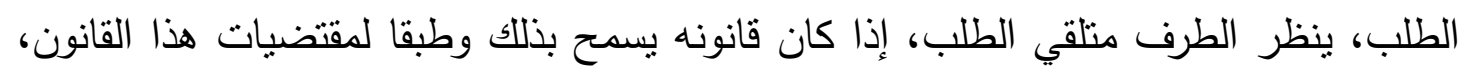

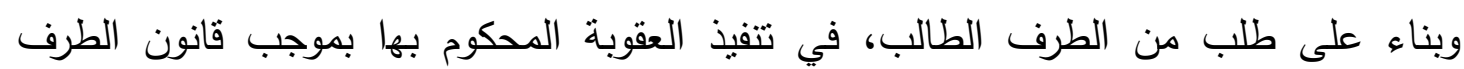

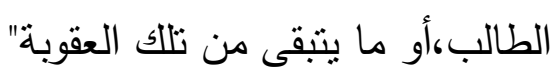

Enforcement requested in accordance with the foregoing provisions may not be refused, in whole or in part, save:...."

4- Article 3

1- A Contracting State shall be competent in the cases and under the conditions provided for in this Convention to enforce a sanction imposed in another Contracting State which is= =enforceable in the latter State.

- This competence can only be exercised following a request by the other Contracting State.

2-ولا تقتصر أهية هذا الثرط على حالة تتفيذ المبائر للحكم الجنائي الأجنبي أيا كانت العقوبة الدحكوم بها-في غير دولة الادانة

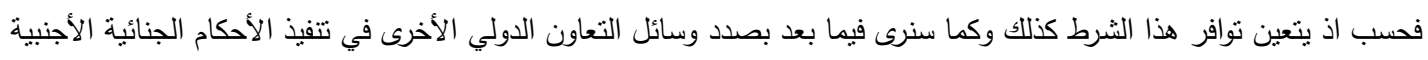

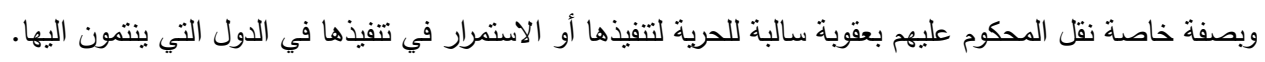

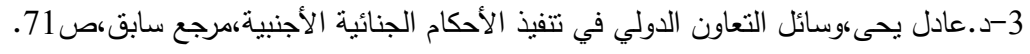


وأيضاً اتفاقية الأمم المتحدة لمكافحة الجريمة المنظمة عبر الوطنية اذ تتص المادة(16)منها

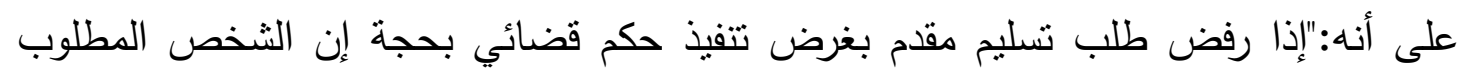

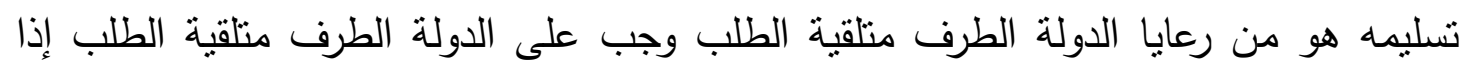

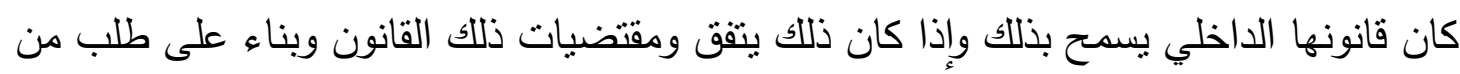
الطرف الطالب إن تتظر في تتفيذ الحكم الصادر بمقتضي قانون الطرف الطالب الداخلي أو تنفيذ ما تبقي من العقوبة المحكوم بها". 
المطلب الثالث

التعاون الدولي في تنفيذ الأحكام السالبة للحرية

باستقراء نصوص العديد من الاتفاقيات الدولية-الثنائية والجماعة-في مجال التعاون القانوني والقضائي في المسائل الجنائية نلاحظ تباين شروط وقواعد تلفيذ العقوبات السالبة للحرية في غير دولة الإدانة.وفي هذا الصدد تبدو أهية الاتفاقية الأوروبية بشأن القيمة الدولية للأحكام

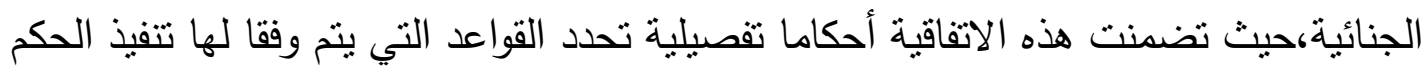
الجنائي الصادر بعقوبة سالبة للحرية في إحدى الدول المتعاقدة في إقليم دولة متعاقدة أخرى. لذلك سوف نعرض لقواعد تتفيذ العقوبات السالبة للحرية في غير دولة الإدانة في ضوء اتفاقيات التعاون القانوني والقضائي في المجال الجنائي ثم بعد ذلك لتلك القواعد في ضوء

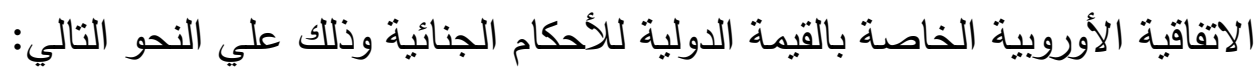
أولاًا-الاتفاقية العربية للتعاون القضائي:

تتص المادة(55)من اتفاقية الرياض العربية للتعاون القضائي علي أنه:"يجوز تتفيذ

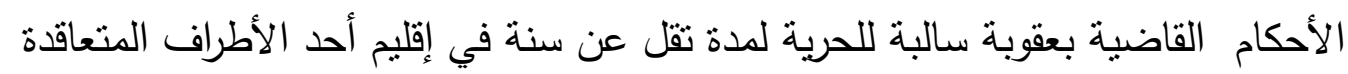

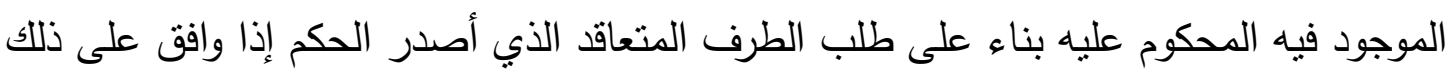

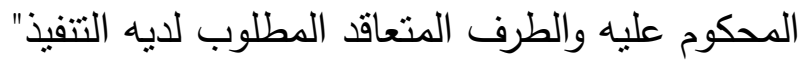
ثانياً-|تفاقية الأمم المتحدة لمكافحة الجريمة المنظمة عبر الوطنية:

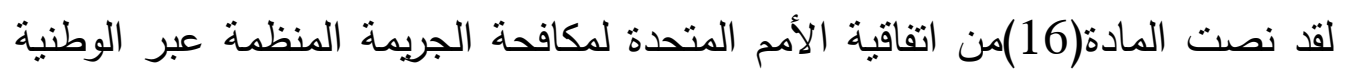

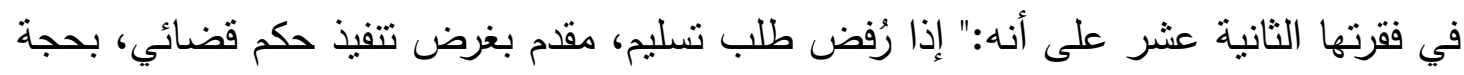

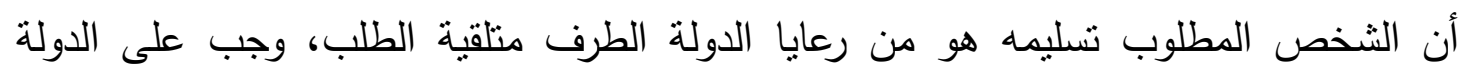

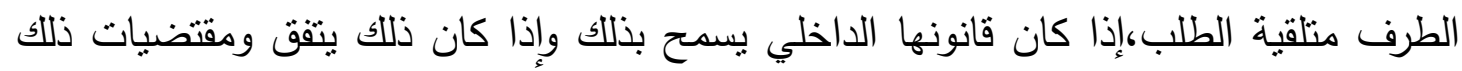

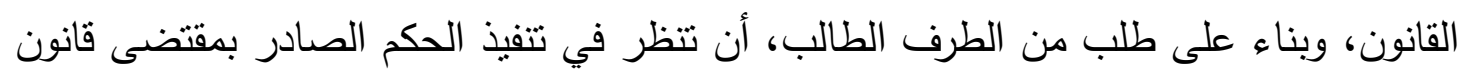
الطرف الطالب الداخلي، أو تتفيذ ما تبقى من العقوبة المحكوم بها".

ثالثاً-|تفاقية الأمم المتحدة لمكافحة الاتجار غير المشروع في المخدرات والمؤثرات العقلية:

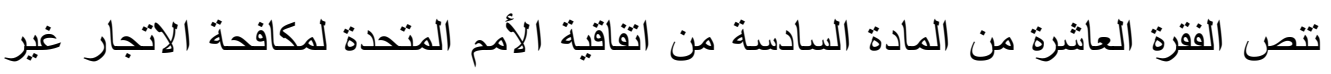

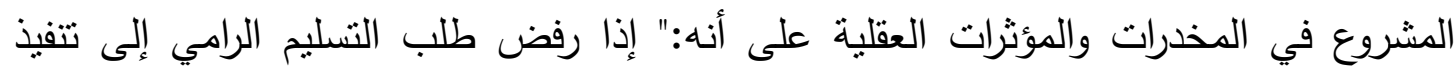

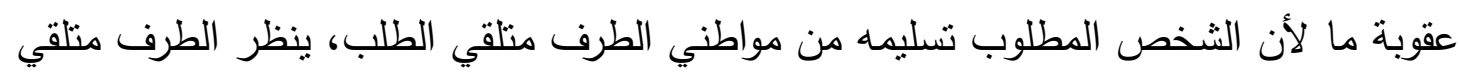

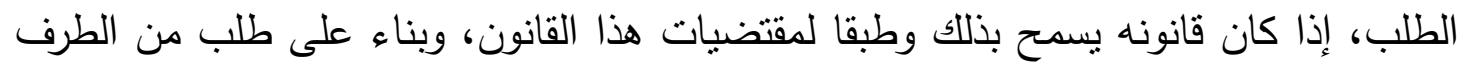


رابعاً-الاتفاقية الأورويية الخاصة بالقيمة الدولية للأحكام الجنائية:

لقد حددت المادنان(43)و(44)من الاتفاقية الاوروبية الخاصة بالقيمة الدولية للإحكام

الجنائية القواعد الخاصة بتتفيذ العقوبة السالبة للحرية المحكوم بها في احدى الدول المتعاقدة في إقليم دولة متعاقدة أخرى. حيث أوجبت المادة(43)من هذه الاتفاقية تمهيداً لتتفيذ العقوبة السالبة للحرية المحكوم بها نقل المحكوم عليه إن كان محبوسا في دولة الإدانة إلى دولة التنفيذ وذلك بمجرد اخطار هذه الأخيرة دولة الإدانة بقبول طلب نتفيذ الحكم(1).

إلا أنه يوجد استثناء يرد على هذه القاعدة فلا يجوز نقل محكوم عليه من دولة الإدانة حتى بعد قبول الدولة الطرف الأخرى تتفيذ العقوبة لديها في الأحوال الآتية: -إذا تبين بعد تقديم طلب النقل والموافقة عليه إن المحكوم عليه هو أحد رعايا دولة الإدانة وكان دستور هذه الدولة الأخيرة يحظر تسليم رعاياها إذا كان للمحكوم عليه الحق في شروط التنفيذ في الدولة المقرر نقلها إليها للتنفيذ(2). والجدير بالذكر إن نقل المحكوم عليه من دولة الإدانة إلى دولة التتفيذ قد بتطلب المرور بإقليم دولة ثالثة وفي هذه الحالة يتعين نطبيق نص المادة(13)من الاتفاقية إذ حددت هذه المادة الثروط التي يلزم توافرها لمرور المحكوم عليه عبر إقليم دولة ثالثة وصور هذا المرور والحالات التي يجوز فيها لهذه الدولة رفض هذا المرور (3).

1- Article 43 :

When the sentenced person is detained in the requesting State he shall, unless the law of that State otherwise provides, be transferred to the requested State as soon as the requesting State has been notified of the acceptance of the request for enforcement.

$$
\text { 2- د. عمر أحمد مراد الكندري،النعاون الدولي في مكافحة الجريمة،هرجع سابق،ص459 }
$$

\section{1- Article 13}

1 The transit through the territory of a Contracting State of a detained person, who is to be transferred to a third Contracting State in application of this Convention, shall be granted at the request of the State in which the person is detained. The State of transit may require to be supplied with any appropriate document before taking a decision on the request. The person being transferred shall remain in custody in the territory of the State of transit, unless the State from which he is being transferred requests his release.

2 Except in cases where the transfer is requested under Article 34 any Contracting State may refuse transit:

a on one of the grounds mentioned in Article 6.b and c;

$\mathrm{b}$ on the ground that the person concerned is one of its own nationals.

3 If air transport is used, the following provisions shall apply:

a when it is not intended to land, the State from which the person is to be transferred may notify the State over whose territory the flight is to be made that the person concerned is being transferred in application of this Convention. In the case of an unscheduled landing such notification shall have the effect of a request for provisional arrest as provided for in Article 32, paragraph 2, and a formal request for transit shall be made;

$\mathrm{b}$ where it is intended to land, a formal request for transit shall be made. 
وتتضمن هذه الاتفاقية شرطاً هاماً يتمنل في مطابقة العقوبة المحكوم بها في دولة الإدانة للعقوبة المقررة لذات الجريمة في دولة التتفيذ واعمالا لهذا الشرط يجوز لقاضي التنفيذ أن يستبدل العقوبة المنصوص عليها في قانون دولته بالعقوبة الصادرة من دولة الإدانة.مع مراعاة ألا يترتب على هذا الإستبدال الإساءة إلى مركز المتهم المحكوم عليه فإذا كانت العقوبة المقرة علي الجريمة المنفذ الحكم من أجلها أثند من العقوبة المحكوم بها فلا ينفذ منها إلا القدر المساوي لعقوبة المحكوم بها في دولة الإدانة(1).

ويراعى وفقا لقواعد العدالة وطبقا للفقرة الثالثة من المادة(44)من الاتفاقية إن يتم خصم مدة العقوبة التي نفذها المحكوم عليه في دولة الإدانة وكذلك مدة الحبس الاحتياطي التي يكون قد أمضاها في دولة التنفيذ(2).

وقد نصت المادة(58)من الاتفاقية على شروط يتعين توافرها لجواز تتفيذ الحكم الصادر من دولة طرف في الاتفاقية لدى دولة طرف أخرى يكون المحكوم عليه من رعاياها وتتمنل هذه

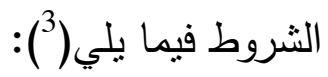

1-أن تكون العقوبة السالبة للحرية المحكوم بها لا تقل مدتها أو المدة المتبقية منها أو القابلة للتنفيذ عن ستة أثهر • 2-ألا تكون العقوبة عن جريمة من الجرائم التي لا يجوز فيها التسليم طبقا للمادة(41)من هذه الاتفاقية.

3-أن تكون العقوبة من أجل فعل معاقب عليه لدى الطرف المتعاقد المطلوب التتفيذ لديه بعقوبة سالبة للحرية لا تقل مدتها عن ستة أثهر . 4-أن يوافق على طلب التنفيذ كل من الطرف الصادر عنه الحكم والمحكوم عليه.

\section{1-Article 44:}

1- د.عادل يحى،وسائل التعاون الدولي في تتفيذ الأحكام الجنائية الأجنبية،مرجع سابق،ص91.

Any part of the sanction imposed in the requesting State and any term of provisional custody,served by the person sentenced subsequent to the sentence, shall be deducted in full. Thesame shall apply in respect of any period during which the person sentenced was remanded in custody in the requesting State before being sentenced in so far as the law of that

\section{2- Article 58}

State so requires.

1 This Convention shall be open to signature by the member States represented on the

Committee of Ministers of the Council of Europe. It shall be subject to ratification or

acceptance. Instruments of ratification or acceptance shall be deposited with the Secretary General of the Council of Europe.

3 The Convention shall enter into force three months after the date of the deposit of the third instrument of ratification or acceptance.

In respect of a signatory State ratifying or accepting subsequently, the Convention shall come into force three months after the date of the deposit of its instrument of ratification or acceptance. 


\section{الخاتمة}

أدى تصاعد التحديات الأمنية، وخصوصا الصراعات المسجلة المحلية والإقليمية والدولية، وانتنار أسلحة الدمار الثامل، والجريمة المنظمة، وظاهرة الإرهاب، إلى زعزعة الاستقرار العالمي وتهديد الأمن والسلم الدوليين. مما يشجع على ضرورة التعاون الدولي لمكافحة

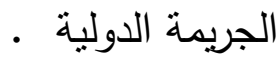

ويعتبر التعاون القضائي الدولي اليوم الآلية الرئيسة في المجال الجنائي لمكافحة الجريمة بشكل هام والجريمة المنظمة بشكل خاص. والتي أصبحت من أكثر الجرائم المهدة للمجتمع الدولي. ذلك أن المساعدة القانونية المتبادلة في المسائل الجنائية. القائمة على التعاون والتتسيق المتبادل بين الدول يعتبران دعامتان أساسيان للوقاية من خطر الجريمة والتصدي لها في نفس الوقت.

وفي هذه الدراسة تتاول الباحث موضوع الدراسة ( التعاون الضائي لمواجهة الجريمة المنظمة) في ثلاث مباحث كالتالي:

المبحث الأول: الإنابة القضائية الدولية. المبحث الثاني: تسليم المجرمين. المبحث الأول: تنفيذ الأحكام الجنائية الأجنبية. وقد انتهت الدراسة إلى مجموعة من التوصيات على النحو التالي: 1- يجب وضع اتفاقية تعاون قضائي في المسائل الجنائية وإلزام المجتمع الدولي والجمعية العامة بها. 2- ضرورة إنشاء جهاز خاص تابع لجامعة الدول العربية ومناشدة كافة الدول العربية للإنضمام 
3- ضرورة العمل من أجل حث الدول غير الموقّعة على نظام روما الأساسي، على احترام

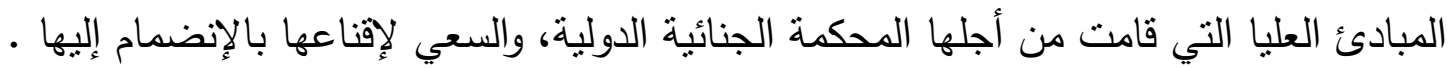

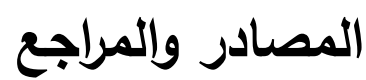

1- د. أحمد عبد الحليم شاكر ،المعاهدات الدولية أمام القضاء الجنائي،المحلة الكبرى،دار الكتب القانونية،سينة 2010،.

2- د. أمين عبد الرحمن محمود عباس،الإنابة القضائية،رسالة دكتوراه،كلية الحقوق،جامعة الاسكندرية،سنة 2011. 3- د. عادل يحي،وسائل النعاون الدولي في تتفيذ الأحكام الجنائية الأجنبية،القاهرةدار النهضة العربية،سنة 2005م.

4- د. عزت محمد العمري،جريمة غسل الأموال، القاهرة ،دار النهضة العربية كسنة2006.

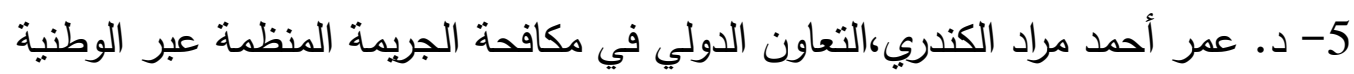

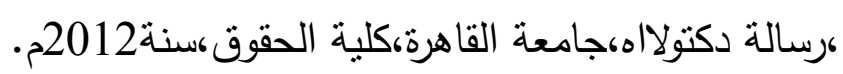
6- د. مأمون محدد سلامة ،قانون الاحكام العسكرية العقوبات والاجراءات ،القاهرة ،دار الفكر العربي كسنة 1984م.

7- د. محمد عيد الغريبهشرح قانون العقوبات القسم العام النظرية العامة للجريمة، القاهرة ، دون ناشر ، سنة 1994. 8- د. محمود نجيب حسني، شرح قانون العقوبات،القسم العام،القاهرةدار النهضة

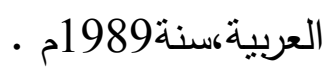

9- د.أحمد إبراهيم مصطفى سليمان،العلاقة بين الإرهاب والجريمة المنظمة وسبل

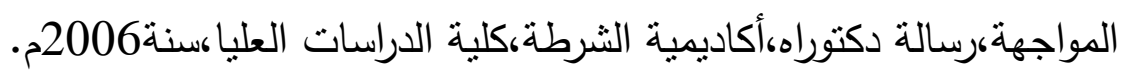
10- د.أحمد أبو الوفا،الوسيط في القانون الدولي العام، القاهرة، دار النهضة العربية، العادية سنة2007م.

11- د.أحمد السيد صـاوي، الوسيط في شرح قانون المرافعات المدنية والتجارية،القاهرة،بدون ناشر ،سنة2005م.

12- د.أحمد عبد الحليم شاكر،الأحكام الإجرائية والموضوعية للمعاهدات الدولية أمام القضاء

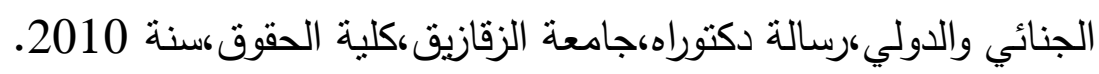

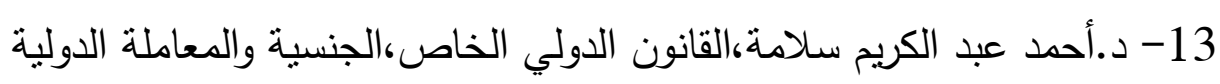
للأجانب،القاهرة ،دار النهضة العربية،سينة 2001. 
14- د.أحمد فتحي سرور، النقض في المواد الجنائية،القاهرةدار النهضة العربية،سنة 1997.

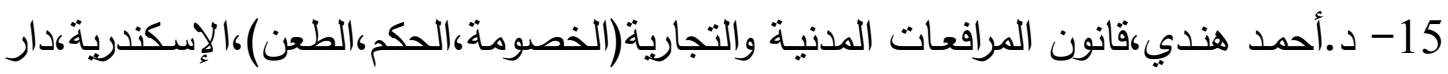
الجامعة الجديدة للنشر كسنة 1995م. 16- د.إدوارد عبد،الإنابات والإعلانات القضائية وفقا لقواعد القانون الدولي الخاص واتفاقية الدول العربية عام 1953م،القاهرة، معهد البحوث والدراسات العربية،سنة 1969. 17- د.السيد رمضان عطية خليفة،تسليم المجرمين في إطار قواعد القانون الدولي،دراسة تأصيلية وتطبيقية،القاهرة،دار النهضة العربية،سنة

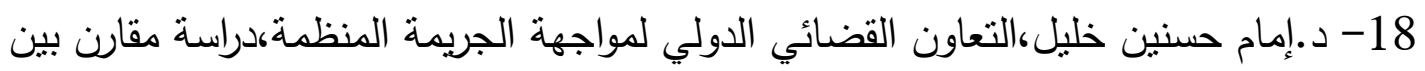

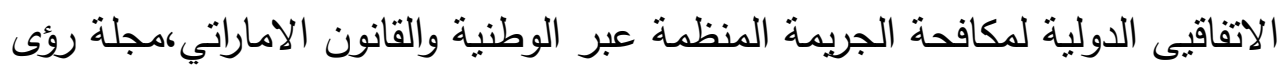
استراتيجية،يناير ،سنة2015م.

19- د.بدر الدين عبد المنعم شوقي،الإنابة القضائية العربية في المسائل الجنائية،هجلة كلية الندريب والتتمية،العدد التاسع عشر ، يوليو 2008م.

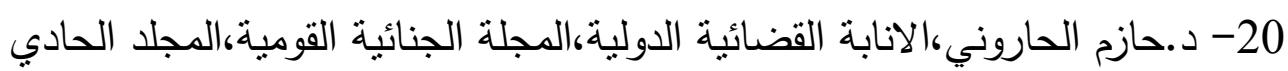
والثلاثتون،العددين الثاني والثالث،يونيو -نوفمبر ،سنة 1988 التابة

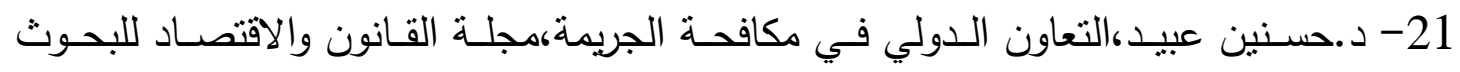
القانونية والاقتصادية،سك53،سنة 1983. 22 د.دهام أكرم عمر ،جريمة الاتجار بالبشر ،دراسة مقارنه،القاهرة،دار الكتب

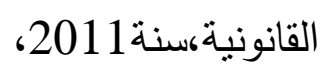

23- د.ذنايب آسية،الآليات الدولية لمكافحة الجريمة المنظمة عبر الوطنية،رسالة

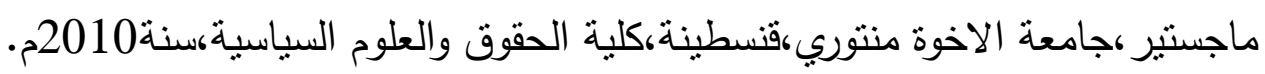
24- د.سلوى توفيق بكير،العقوبة في القانون الجنائي المصري،القاهرة ،دار النهضة العربية العبية مسنة

25- د.سليمان عبد المنعم،الجوانب الإثكالية في النظام القانوني لتسليم المجرمين دراسة مقارنة،الاسكندرية،دار الجامعه الجديدة،سنة 26- د.طارق سرور ،الاختصاص الجنائي العالمي،القاهرة،دار النهضة النية

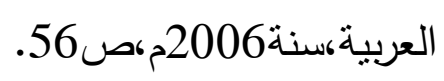

27- د.عادل يحى،وسائل التعاون الدولي في تتفيذ الأحكام الجنائية الأجنبية،

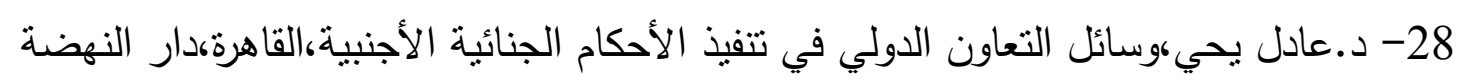

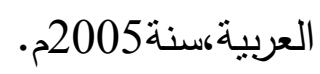


29- د.عبد الرحمن فتحي سمحان، تسليم المجرمين في ظل قواعد القانون الدولي،القاهرةدار النهضة العربية،سنة2011.

30- د.عبد العليم عبد المجيد مشرف،الرقابة على دستورية المعاهدات الدولية،دراسة مقارنة، القاهرة، دار النهضة العربية،سنة 2010م. 31- د.عبد الفتاح محمد سراج،النظرية العامة لتسليم المجرمين،رسالة دكتوراه،جامعة المنصورة،كلية الحقوق،سنة 1999،

32- د.عبد المنعم حسن علي،السياسة الجنائية في مواجهة جرائم الاتجار بالبشر ،القاهرة،دار 2017، النهضة العربية،سنة 2017، د. 2017.

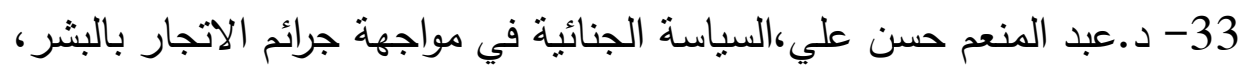

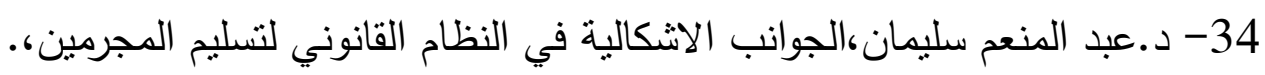
35- د.عكاشة محمد عبد العال،الإنابة القضائية في نطاق العلاقات الخاصة الخية الدولية،الإسكندرية، دار المطبوعات الجامعية،سينة دابة 1994م. 36- د.عمر سالم،الإنابة القضائية الدولية في المسائل الجنائية دراسة مقارنة،القاهرة،دار النهضية

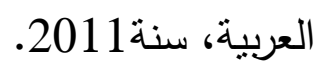
37- د.عمر سالم،التعاون الدولي في تتفيذ الأحكام الجنائية الأجنبية،مجلة الفكر الثرطي،القيادة

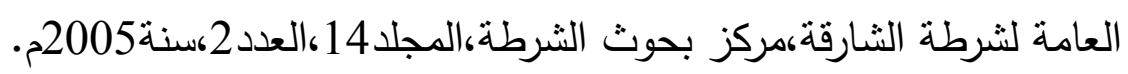
38- د.فائزة يونس الباشا،الجريمة المنظمة في ظل الاتفاقيات الدولية والقوانين الوطنية،دراسة

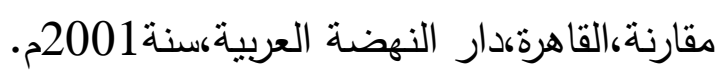

39- د.فتحي المصري بكر،قوة الثئ المقضي به في المجال الجنائي،رسالة دكتوراه،جامعة القاهرة،كلية الحقوق،سنة 40- د.محمد زهير جرانة،أثز الأحكام الجنائية الأجنبية في مصر ،مجلة القانون والاقتصاد، كلية

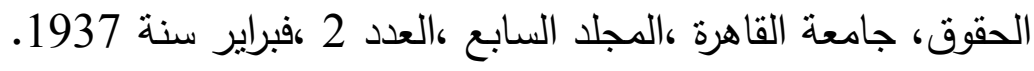

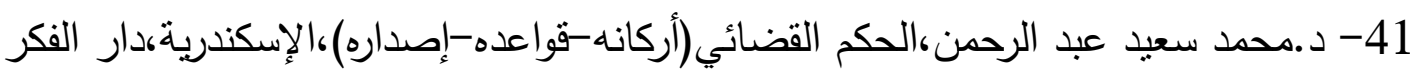
الجامعي،سنة2008.

42- د.محمد عبد القادر العبودي، ندب مأمور الضبط القضائي لأعمال التحقيق،القاهرة، دار النهضة العربية،سنة 2006م. 43- د.محمد فاضل،التعاون الدولي في مكافحة الإجرام،حلب، منشورات جامعة حلب،سنة 1992م. 44- د.محمـود السـيد عمـر التحيوي،النظريـة العامـة لأحكـام القضاء،الإسـكندرية،دار ملتقى الفكر ،سنة 2001م. 
45- د.محمود نجيب حسني،شرح قانون الاجراءات الجنائية،القاهرةدار النهضة

العربية،سنة 1998م.

45- د.محمود نجيب حسني،قوة الحكم الجنائي في انهاء الدعوى الجنائية،القاهرةدار النهضة

العربية،سا1977م.

46- د.مسعودي الثريف،الآليات الدولية لمكافحة الجريمة المنظمة العابرة للحدود الوطنية،رسالة ماجستير ،جامعة امحمد بوفرة-بومرداس،كلية الحقوق،سنة 2015م.

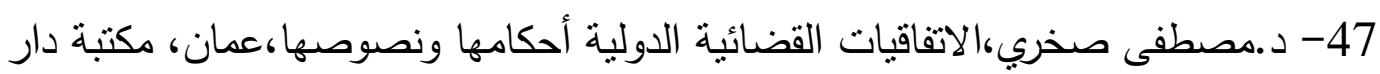

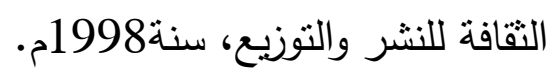

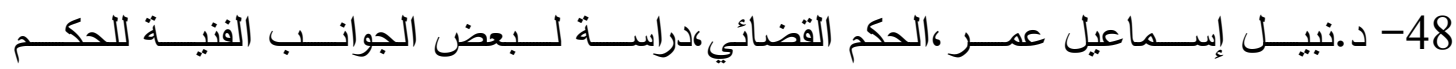

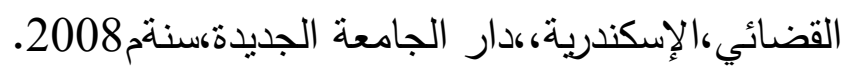

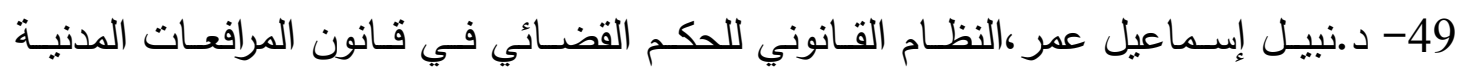
والتجارية،الإسكندرية،دار الجامعة الجديدة،سنة دعبة 2006م.

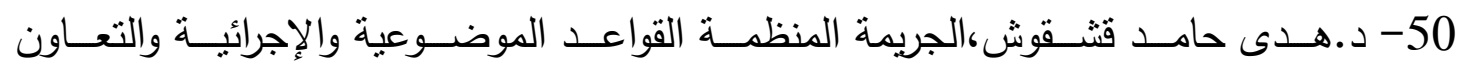

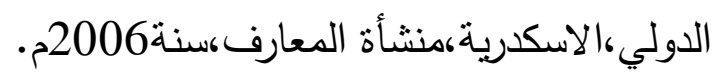
51- د.وجدي راغب ود.سيد أحمد محمود،قانون المرافعات الكويتي،الكويت،مؤسسة دار الكتب للطباعة،سنة 1994م.

52- مسعودي الثريف،الآليات الدولية لمكافحة الجريمة المنظمة العابرة للحدود الوطنية،رسالة ماجستير ،جامعه أمحمد بوقرة-بومرداس،كلية الحقوق،سنة 2015م.

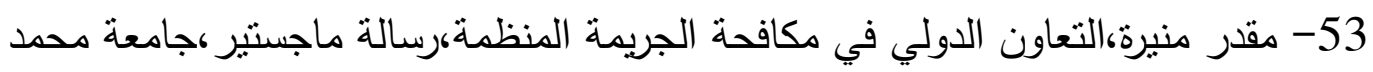
خضير ،كلية الحقوق والعلوم السياسية،سنة 2015م. 54- د.عبد الغني محمود،نسليم المجرمين على أسباب المعاملة بالمثل،هالقاهرة،دار النهضية العربية،سنة 1991م.

$$
\text { - للمزيد من المعلومات حول هذه المعاهدات راجع في ذلك: }
$$

Richard Crawford Pugh,Oscar Schachter, Hans Smit, Louis Henkin, International Law: Cases and Materials, West Publishing Co., 2001.p81...ets

$$
\text { اتباع القواعد الخاصة بإجراءات المحاكمة والتحقيق النهائي اللازم للحكم الجنائي. }
$$

4- "European criminal judgment" means any final decision delivered by a criminal court of a Contracting State as a result of criminal proceedings 1- André Huet, Les conflits de lois en matière de preuve, Paris , Dalloz,1965,p.348 
2- André Huet, Renée Koering,Joulin, Droit pénal international, Presses Universitaires de France in Paris, 2005,p327. 